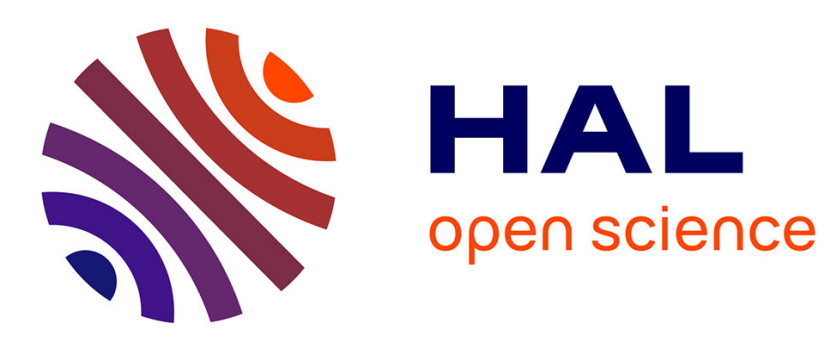

\title{
Modernization Before Industrialization: Cultural Roots of the Demographic Transition in France
}

\author{
Guillaume Blanc
}

\section{To cite this version:}

Guillaume Blanc. Modernization Before Industrialization: Cultural Roots of the Demographic Transition in France. 2020. hal-02318180v8

\section{HAL Id: hal-02318180 \\ https://hal.science/hal-02318180v8}

Preprint submitted on 15 Nov 2020 (v8), last revised 2 Dec 2021 (v9)

HAL is a multi-disciplinary open access archive for the deposit and dissemination of scientific research documents, whether they are published or not. The documents may come from teaching and research institutions in France or abroad, or from public or private research centers.
L'archive ouverte pluridisciplinaire HAL, est destinée au dépôt et à la diffusion de documents scientifiques de niveau recherche, publiés ou non, émanant des établissements d'enseignement et de recherche français ou étrangers, des laboratoires publics ou privés. 


\title{
Modernization Before Industrialization: Cultural Roots of the Demographic Transition in France
}

\author{
Guillaume Blanc, Brown University*
}

November 2020 (latest version)

\begin{abstract}
This research identifies the origins of the early demographic transition in eighteenth-century France. A turning point in history and an essential condition for development, the demographic transition first took hold in France more than a hundred years before any other country-and this event remains one of the "big questions of history" because of its timing and limited data availability. My results suggest that secularization accounts for the decline in fertility. I document an important and early process of dechristianization with never-before-used data on religious beliefs across time and space. Using census data, I show a strong association between religiosity and the timing of the transition. Finally, I draw on a novel dataset crowdsourced from publicly available genealogies to study individuals at the time. In order to establish a causal interpretation, I control for time-varying unobservables with fixed effects, study the effect of religiosity before and after secularization with difference-in-differences, and exploit the choices of second-generation migrants to account for unobserved institutional factors. These findings reveal that changes in preferences and the transition away from tradition may shape development.
\end{abstract}

JEL codes: N33, O10, Z12

Keywords: fertility, development, secularization

And the race of man cannot, by any efforts of reason, escape from it. -Thomas Malthus, An Essay on the Principle of Population (1798)

\section{INTRODUCTION}

The demographic transition is a watershed moment in the process of development. For most of human history, improvements in standards of living were offset by demographic expansion and populations trapped into stagnation. With the advent of limitations of fertility, income

\footnotetext{
* Department of Economics, Robinson Hall, 64 Waterman Street, Providence RI 02912, guillaume_blanc@brown.edu. I would like to warmly thank Oded Galor, Stelios Michalopoulos, Romain Wacziarg, and David Weil for their kind support and dedicated supervision. This research has benefited from insightful comments and suggestions of Philipp Ager, Philippe Aghion, Thomas Baudin, David le Bris, John Brown, Greg Clark, David Cuberes, David de la Croix, Klaus Desmet, Sergey Egiev, Raphaël Franck, Timothée Gigout, Paula Gobbi, Phil Hoffman, Taylor Jaworski, Ezra Karger, Clément Malgouyres, Joel Mokyr, Nathan Nunn, Thomas Piketty, Michele Rosenberg, Lukas Rosenberger, Jared Rubin, Mara Squicciarini, Enrico Spolaore, Uwe Sunde, Emmanuel Todd, and members of the Growth Lab at Brown. I also thank seminar and conference participants at ASREC, Brown University, Chapman University, Clark University, College de France, EHA, EMCON Chicago, Ludwig Maximilian University, Northwestern University, Paris School of Economics, UC Davis, and Université Catholique de Louvain for helpful comments and discussions. I am grateful to the Population Studies and Training Center at Brown University, which receives funding from the NIH, for training support (T32 HD007338) and for general support (P2C HD041020). Raphaël Franck, Victor Gay, Masahiro Kubo, Stelios Michalopoulos, Claude Motte, and Julien Perret kindly shared data. Any missing E is Apple's butterfly keyboard's own. All remaining errors are my own.
} 
per capita was allowed to rise above subsistence in a sustained way. Traditional explanations for the transition document the central role played by industrialization and the importance of human capital with a trade-off between the quantity and quality of children. Yet, a shift away from tradition and dramatic cultural upheavals also took place with the emergence of modern economic growth in the eighteenth and nineteenth centuries. Did industrialization and development come first? Or did cultural changes pave the way for income per capita to rise above subsistence level?

This paper argues that secularization, not development, brought about the demographic transition in eighteenth-century France; modernization materialized before industrialization. Why the historical fertility transition started in France first, before the French Revolution and more than a century before the rest of the world, is a mystery because of a lack of available data so long ago. ${ }^{1}$ It is one of "the big questions of history" (Darnton, 1978) and, according to Sauvy (1962) "the most important fact of her [France] entire history". Because the demographic transition took hold in France so early and in a period of stagnation, it is an exceptional experiment to study the effect of social norms on development.

In many ways, France was a developing country in the eighteenth century. In 1750, literacy in France was half that of England and Wales. France attained the GDP per capita of 1750 England and Wales, the cradle of the Industrial Revolution, only in the aftermath of World War I, and it took more than two centuries to achieve the rate of urbanization of 1750 England: only in 1950 did the urban population begin to outnumber the rural population in France. Nevertheless, England and the rest of Europe went through the demographic transition between 1870 and 1920, after the Industrial Revolution, while the onset of the decline in fertility in France is dated to the second half of the eighteenth century, between 1760 and 1776 .

Also before any other country, dechristianization took hold in eighteenth-century France with an important loosening of traditional religious moral constraints (Chartier, 1991; Van Kley, 1996; Vovelle, 1982). Braudel (1986b) evokes "the liberation of Frenchmen from the teachings, the restrictions, and the yoke of the Catholic Church". The weakening of the moral authority of the Roman Catholic Church left a profound and lasting impact on France. Secular beliefs spread "in a veritable flood" (Tackett, 1986, p. 252) and "irreligion was able to become a general and dominant passion" (de Tocqueville, 1856, Book 3, Chapter 2). In some regions the move away from religion took place exceptionally early, in the first half of the eighteenth century (Vovelle, 1973).

Using a variety of empirical methods with département-level population counts in census data and a novel individual-level dataset crowdsourced from publicly available genealogies, I establish that places that remained more religious experienced the transition to low fertility earlier, suggesting that the wave of secularization played a significant role in the

\footnotetext{
${ }^{1}$ See, among many others, Coale and Watkins (1986); Cummins (2012); Henry (1972a,b, 1978); Henry and Houdaille (1973); Knodel and Van de Walle (1979); Murphy (2015); Weir (1994); Wrigley (1985a,b).
}

Page 2 of 43 
demographic transition.

I exploit variation in the intensity of religious beliefs after secularization, proxied by the population-weighed share of refractory clergy in 1791 (Tackett, 1986). The Civil Constitution of the Clergy, passed in July 1790, required all priests and vicars to take an oath of allegiance to the secular state and transformed clergymen into civil servants. The oath had to be taken "on a Sunday at the conclusion of the mass" (Decree on the clerical oath). The presence of refractory clergy is highly correlated with all other available measures of religiosity and especially easter attendance - which is only available in 1966. It is a standard measure of devotion and loosening attachment to religion, used in particular by Squicciarini (2020) to study the effect of devotion on education and industrialization after 1870 . The data is available at the département and district levels.

In order to capture the extent of secularization and not pre-existing differences, I control for proxies for religiosity before secularization in most regressions. Additionally, I leverage novel and detailed micro-level data on secular beliefs and preferences across time and space in wills at death in the region of Provence from 1690 to 1789 (Vovelle, 1973) to measure dechristianization. Using spatial variation, I also show that the share of refractory clergy following the oath of 1791 reflects not only the devotion of laypeople at the time of the French Revolution but is the product of the rise in secular attitudes that took place over the previous hundred years. These results suggest that the main independent variable captures dechristianization in the eighteenth century rather than pre-existing differences.

In the main empirical analysis at the département level, I evaluate the cross-sectional determinants of the timing of the transition to low fertility with census data from 1831 to 1961. Using ordinary least squares and maximum-likelihood in order to account for censoring with a Tobit model, I estimate remarkably strong, significant, and robust coefficients across specifications. Decreasing religiosity from the 75 th to the 25 th percentile of the distribution predicts a delay in the year of transition of more than one standard deviation, and I show that no other variable has an impact nearly as important.

I provide different strategies to show the robustness of the results and to suggest a causal effect using this data. First, I estimate bounds on the effect of religiosity across 131, 072 potential models, or all combinations of covariates, using sensitivity analysis (Brodeur, Cook and Heyes, 2020b; Leamer, 1983). Not a single specification returns a coefficient for religiosity in 1791 that is either statistically or economically insignificant. Then, instead of using all covariates, I turn to variable selection. Because the roots of dechristianization in France are not well understood, I use lasso, a supervised machine-learning technique that relies on a selection-and-shrinkage algorithm to find the best available predictors in a context with a large number of covariates (Tibshirani, 1996). In particular, double-lasso variable selection allows to select variables which may account for pre-existing or confounding factors in the distribution of both religiosity and fertility. Last, I account for spatial correlation and omitted variables. I find that fixed effects remove the spatial dependence, 
and I compute Conley-adjusted standard errors at different cutoffs to improve the precision of the estimation. I run thousands of simulations by replacing the independent and dependent variables with spatially correlated noise (Kelly, 2019) and find that only a negligible portion of these regressions returns significant coefficients. In order to account for omitted variables, I estimate coefficients adjusted for selection on unobservables, with standard errors bootstrapped over thousands of replications (Oster, 2016). The results suggest that the OLS coefficient on religiosity is biased downward, in line with evidence suggesting that secularization hit poor and rural areas disproportionately and was a separate process from the spread of the Enlightenment. ${ }^{2}$

Finally, I study ordinary individuals at the time of the decline in fertility by using a novel crowdsourced historical dataset spanning several centuries and containing all publicly available genealogies on geni.com (Blanc, 2020; Kaplanis et al., 2018). Individuals born all over France, in rural and urban areas, are included. I show that the dataset is a representative sample and that selection into the sample is limited from roughly 1680 to 1920. I find that individuals born in places with high religiosity have more children; the effect is large, statistically significant, and robust. I estimate the effect of religiosity on fertility with Poisson, OLS, overdispersed-Poisson, and negative-binomial regressions, and, using distribution regressions (Chernozhukov, Fernández-Val and Melly, 2013), I show that large families experienced the largest drop in fertility as religiosity declined.

I reach plausibly causal estimates with the aid of different strategies applied to this setting for the first time. First, I study individuals born in the same départements and account for time-varying département-level cultural and institutional unobservables with département-by-decade fixed effects (there is limited within-département variation in institutional factors). Then, I apply a difference-in-differences estimation method by comparing the effect of religiosity before and after the onset of secularization in the mid-eighteenth century. I find that religiosity in 1791 was positively associated with fertility after secularization took place but had a null and insignificant effect before, which suggests again that dechristianization, and not unobservable pre-existing differences, is being captured. Last, I study second-generation migrants in order to control for unobserved institutional factors. This is the first research to implement this estimation strategy in a historical setting and at such a granular level. I compare individuals born in the same district but originating from different places and find that religiosity in the district in which their parents were born had a large effect on fertility, which persisted for generations and through migrations.

This paper makes numerous contributions. I identify the change in preferences at the root of the early demographic transition in France: dechristianization and the move away from the teachings of the Roman Catholic Church. ${ }^{3}$ Second, I contribute to a literature

\footnotetext{
${ }^{2}$ Historians have also rejected the idea that changing religious beliefs were linked to improved standards of living or to the spread of a bourgeois ideology from elites to peasants (Hoffman, 1984; Vovelle, 1973).

${ }^{3}$ I also contribute to a literature that has emphasized the role of secular forces, often in the nineteenth and twentieth centuries, on fertility behaviors (Hacker, 1999; Lesthaeghe, 1983, 2010) and those forces' interaction with 
that has documented profound changes in religious beliefs in eighteenth-century France (Van Kley, 1996; Vovelle, 1973) with important consequences (Le Bras, 1942-5; Todd and Le Bras, 1981). Third, I contribute to a vibrant literature that has documented the persistence of culture over the very long run (Ashraf and Galor, 2013; Spolaore and Wacziarg, 2013; Voigtländer and Voth, 2012), but I empirically establish that cultural change, not persistence, is a determinant of development. Fourth, this is the first research to exploit crowdsourced genealogies in order to study ordinary individuals in the past and the spatial determinants of fertility at the time of the demographic transition. Finally, the paper contributes to a large literature on the cultural and religious origins of the transition to sustained growth (Bénabou, Ticchi and Vindigni, 2015; McCloskey, 2016; Mokyr, 2016; Schulz et al., 2019; Squicciarini, 2020; Squicciarini and Voigtländer, 2015).

\section{HistoricAl BACKGROUND AND LiterATURE}

\subsection{Demographic transition and development}

In every respect, eighteenth-century France lagged one to two hundred years behind England, the cradle of the Industrial Revolution. France attained the GDP per capita enjoyed by England and Wales in 1750 only in the 1920s (Bolt and van Zanden, 2014; Lévy-Leboyer and Bourguignon, 1985), the rate of urbanization England had in 1750 in 1950 (Bairoch, Batou and Chèvre, 1988), and the rate of literacy England had in 1650 in 1850 (Buringh and van Zanden, 2009). Weber (1976) depicts French people as "peasants" and "savages", Crouzet (2003) notes that "France remained fundamentally a peasant-based rural economy. Only in 1911 did employment in industry overtake that in agriculture" (p. 236), and Lévy-Leboyer (1968) discusses "the absence of a take-off in France".

Despite the absence of industrialization in France, GDP per capita increased at the same rate in France and England after 1750 and throughout the nineteenth century (Appendix Figure A2.1.1). The rate of population growth in England largely surpassed that in France: in the two centuries following 1750, the population of England increased from 5.5 to 40 million inhabitants, while the population of France increased from 24.5 to 40 million. Figure 1 displays fertility in France and in England and Wales between 1680 and 1920. In the 1750s and throughout the second half of the eighteenth century, average fertility significantly declined in France, while it remained significantly higher in England and Wales until the end of the nineteenth century.

The early decline in fertility, a century before the rest of Europe, in an epoch of stagnation and before the French Revolution, has been the subject of numerous studies, yet why France experienced the demographic transition this early remains an open question. There is widespread agreement that cultural forces played a role (Braudel, 1986b; Sauvy, 1962), 
but it remains one of the most important unsolved puzzles in historical demography and economic growth. The lack of data on an event taking place so long ago has so far hampered the effort to understand the roots of the decline. Demographer Louis Henry used methods of family reconstitution with parish records to reconstruct series of fertility in the eighteenth century (Henry, 1972a,b, 1978; Henry and Houdaille, 1973), and Coale and Watkins (1986) tried to assess the importance of economic and cultural factors in Europe using census data. However, parish-level studies do not offer sufficient spatial variation and suffer from many limitations, which I detail in Section 3.3, and census data only became available in 1831, long after the start of the demographic transition.

Figure 1: Demographic transition in France and England

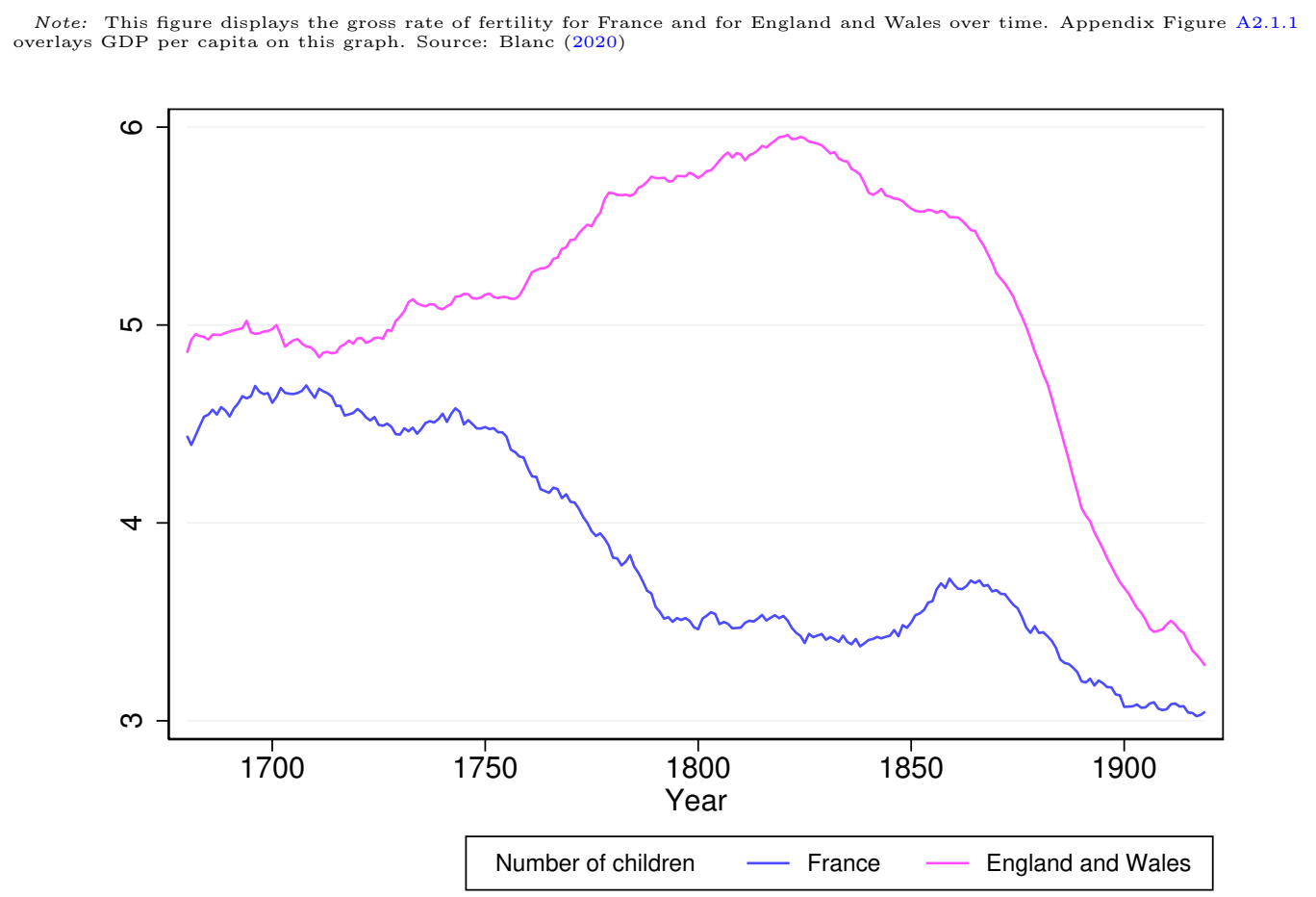

Contraception and the Catholic Church. Declining fertility was also noticed by contemporary observers and was attributed at the time to changing moral standards and preferences. In 1778 Jean-Baptiste Moheau famously used the term 'funestes secrets': "Already the fatal secrets unknown to any animal but man have penetrated in the countryside: nature gets cheated even in the villages." Moheau (1778) referred to the "propagation of the species as a dupery of olden times," and according to Goudar (1756), "It is the same love of ease and convenience that is filling France with bachelors ... men who vanish from the world with all their posterity" (p. 271). Van de Walle and Muhsam (1995) provide a detailed and fascinating account of the evolution of sexual and moral preferences in the 
eighteenth century, in particular regarding the spread of coitus interruptus (withdrawal).

If modern methods of contraception became available well after the onset of the fertility decline, how did fertility decline? Early condoms, known as redingotes d'Angleterre, or 'English riding coats', were expensive and uncommon although they became more widespread in the Age of Enlightenment (for example, in his memoirs, Casanova reports radically changing his behavior and resorting systematically to condoms after 1760). Other methods of contraception include chastity (one of the seven virtues of the Christian faith), late marriage, sodomy, abortion, and infanticide (Van de Walle, 2005). Van de Walle and Muhsam (1995) also write of 'the pleasures of the little goose' (les plaisirs de la petite oie) to refer to mutual masturbation. These methods were less relevant since natural means of contraception such as coitus interruptus were no secret. ${ }^{4}$ Indeed the method of withdrawal "is mentioned in the Bible, the Talmud and the Muslim tradition" (Van de Walle, 2005). Van de Walle (2005) argues that it "was frequently alluded to in libertine literature" (p. 2), which was particularly widespread in eighteenth-century France (Darnton, 1991) in such works as Venus in the Cloister or The Nun in her Smock (1683), The Indiscreet Jewels (1748) by Diderot, and Philosophy in the Bedroom (1775) by the Marquis de Sade. Yet methods of cheating nature were practiced not only by the elite but also by peasants in the villages (Moheau, 1778), and it appears that withdrawal was the most widespread and efficient method at the time.

What were the views of the Catholic Church regarding contraception and sex remains an open question. The Bible urges, multiple times, the faithful to "be fertile, increase in number, and fill the earth" (Genesis 9:1), and the account of the sin of Onan designated both masturbation and 'unnatural' intercourse as evil. Still, the pronouncements of the church against contraception, while clear, were often discrete and indirect (Noonan, 1965). ${ }^{5}$ In 1439, the multiplicative purpose of marriage "received its strongest official approval" (Noonan, 1965, p. 276) in the Exultate Deo papal bull: "Through matrimony [the church] is corporally increased." With the Council of Trent (1545-63) and the CounterReformation, the views of the Catholic Church shifted toward more sexual austerity outside of marriage and an increased sacramentality of marriage, suggesting the increased importance of these matters. Hoffman (1984) argues that "evidence of the new sexual morality appears throughout the Counter Reformation: bans upon nudity in religious art, harsher rules against illegitimacy, prostitution, and concubinage, and more 'puritanical' standards of dress and behavior."

According to Van de Walle and Muhsam (1995), "The orthodox position available to French literati in the late sixteenth century [was that] it is considered sinful in marriage

\footnotetext{
${ }^{4}$ As opposed to its Catholic counterparts-implexus restrictus for non-ejaculation and amplexus reservatus for nonpenetrative, rubbing-only sex-which were not very widespread.

${ }^{5}$ One of the inner struggles in the sexual morality promoted by the Catholic Church relates, indeed, to the dilemma between the multiplicative purpose of marriage and the sinful nature of 'things of the flesh' (Noonan, 1965). Noonan (1965) argues that "the value placed on human fecundity in the Old Testament as a whole is evident ... fruitfulness is a divine reward" (p. 31).
} 
to ejaculate outside of the natural receptacle (ex vas naturale), and only somewhat less sinful to use "unnatural positions'" (p. 269): not only were innovations sinful, but the purpose of marriage was explicitly multiplicative. In the seventeenth century, notorious clergy members such as Francis de Sales and Pierre de Bourdeilles (Brantôme) referred to withdrawal and other contraceptive methods and argued that 'marital fertility should not be interfered with' (Van de Walle and Muhsam, 1995). For example, in Les Dames galantes, published in 1666, "Brantôme concludes that the belief that marriage is instituted for pleasure is wrong and that the greatest blessing God can send in marriage is 'a good lineage and not through concubinage" (Van de Walle and Muhsam, 1995, p. 269). Hence, there is mounting evidence that the Catholic clergy in the eighteenth century understood marriage and sex to be acts of procreation, as opposed to pleasure. In the early eighteenth century, the sacramentality of marriage was also increasingly criticized by the lay population - especially following the Edict of 1715 forbidding Protestants from marrying and after the controversy of the billets de confessions in the 1750s when the Church denied sacraments and burial in consecrated ground to Jansenists (Maire, 2019). For this reason, when secularization took place, the move away from the teachings of the Roman Catholic Church may have played a role in the decline in fertility.

Theory and empirics. According to standard economic theory, development is the best contraceptive (Hansen and Prescott, 2002; Kremer, 1993). The endogenous-growth models developed by Galor (2011); Galor and Weil (2000); Galor and Moav (2002) shed light on the interaction between human-capital accumulation, fertility, and technological progress in the long run: in the course of history, as technological progress accelerates, the return to human capital rises and fertility decisions are altered, triggering the transition. While a society is in the Malthusian trap, income per capita fluctuates around subsistence level because of the positive relationship between income and fertility. When quality is favored to quantity, the relationship reverses and the economy enters the modern growth era, in which human capital is the driver of progress. Institutional, cultural, and geographic factors interact with these forces but are not the main determinants of change.

In recent years, a number of empirical studies have tried to assess the forces driving the demographic transition in France, especially by weighing the relative importance of economic and cultural forces broadly (de la Croix and Perrin, 2018; Murphy, 2015). ${ }^{6}$ On the cultural origins of the transition, Blanc and Wacziarg (2020); Daudin, Franck and Rapoport (2018) study the diffusion of norms of limited fertility within France and Spolaore and Wacziarg (2019) show that the reduction in the rate of fertility in nineteenth-century Europe was driven by a diffusion of norms originating in France. ${ }^{7}$ Yet no research has

\footnotetext{
${ }^{6}$ Murphy (2015) suggests that the French Revolution may have been one of many causes of the decline. He examines the cross-sectional determinants of fertility in France and devotes a couple of paragraphs to the effect of the oath on fertility at the département level in 1831. In a similar fashion, González-Bailón and Murphy (2013) study the role of social interactions on fertility following the Revolution.

${ }^{7}$ The existence of deep-rooted barriers to the adoption of innovation has been documented in Spolaore and 
empirically established the cause of the decline in fertility in France.

\subsection{Religion and secularization in France}

Since medieval times, France has been portrayed as "the eldest daughter of the Roman Catholic Church," French kings as "Rex Christianissimus" or 'most Christian king', and the French as "God's chosen people" (Burleigh, 2005, p. 23). This section briefly summarizes religious history in France until a radical change in beliefs and religiosity took place in the mid-eighteenth century.

Before secularization France was a major Roman Catholic country that hosted seven successive popes from 1309 to 1378. During the Renaissance, and particularly after the reign of Francis I, Protestantism marginally spread, reaching an estimated 10 percent of the population in the mid-sixteenth century (most of these Huguenots). The second half of the sixteenth century was a period of violent religious wars and political unrest, a period whose apex was the massacre of thousands of Protestants on Saint Bartholomew's Day in 1572. In 1593, after fighting a war of succession against the Holy League to gain access to the throne, Henry IV of France renounced Protestantism and, for the second time since Saint Bartholomew's Day, was forced to convert to Catholicism. The promulgation of the Edict of Nantes in 1598 finally put an end to the French Wars of Religion by granting Huguenots substantial rights and freedom of religion.

In the seventeenth century, France remained predominantly Catholic, and in 1685, Louis XIV revoked the Edict of Nantes with the Edict of Fontainebleau, effectively ending religious toleration. The edict deprived Protestants of all religious and civil liberties and ordered the destruction of Huguenots' churches. Dragonnades - policies of legal persecution and forced conversion of Protestants ordered by Louis XIV - epitomized the fight and terror against the Protestant Reformation: dragoons (infantry soldiers) were billeted in Protestant households in order to harass and intimidate the Huguenots. Thousands of Protestants left France, and it set the course for the diffusion and strengthening of the Catholic resurgence. ${ }^{8}$

With the demise of Protestantism, the Counter-Reformation was able to spread unchecked for the most part with the rise of Jansenism, a pious, austere, and rigorist theological movement unique to France Chartier (1991); Van Kley (1996). Jansenists were at the center of the controversies and clashes of the time, especially with the monarchy and Jesuits, who embodied the religious and economic elite and were also at the forefront of the Counter-Reformation. ${ }^{9}$ Appendix Section A2.2 provides further details on clashes involving Jansenists, Jesuits, and the monarchy. Elites strongly opposed Jansenism, which sought

Wacziarg (2009). See also Delventhal, Fernández-Villaverde and Guner (2019) for the diffusion of the fertility transition across countries and Beach and Hanlon (2019) for a fascinating account of changing norms of fertility following the Bradlaugh-Besant trial of 1877 in England.

${ }^{8}$ See Hornung (2014) for the long-run effects of the forced migration of Huguenots to Prussia.

${ }^{9}$ Tackett (1986) writes that "during the first half of the eighteenth century, one issue in diocesan politics dominated all others: the issue of Jansenism" (p. 128). 
to advance ideas of predestination of the elect to salvation, limitation of the sacraments, and the need for penitence-ideas also advanced in Protestantism. The opposition was not only theological but also political, as Jansenists came to embrace Gallicanism, a movement promoting the independence of the Church of France from not only the pope, but also a monarchy endowed with divine right (Maire, 1998, 2019). What links these events to secularization is unclear, but Jansenism and Gallicanism played an important role in eighteenth-century France.

Secularization. In the mid-eighteenth century, dechristianization spread to many regions of France. ${ }^{10}$ In comparison to the rest of Europe, the loss of moral influence of the Roman Catholic Church took place exceptionally early and at a particularly important scale in France (Todd, 1990). According to Tackett (1986) secular beliefs spread "in a veritable flood" (p. 252), de Tocqueville (1856) writes that "irreligion was able to become a general and dominant passion in eighteenth-century France" (Book 3, Chapter 2), and historian Braudel (1986b) evokes "the liberation of Frenchmen from the teachings, the restrictions, and the yoke of the Catholic Church".

Secularization and its timing have been documented by historians in a number of regions. In particular, Vovelle (1973) documents a transition to secular attitudes and mutation de sensibilité collective in a fascinating and path-breaking study of Provence, in the south east of France. Similarly, Hoffman (1984) and Norberg (1985) find substantial changes in the rural parts of the diocese of Lyon and in the diocese of Grenoble in the eighteenth century. The change in attitudes could be observed in a decline in bequests and legacies for perpetual masses and offerings to the church, a decline in requests for burials in holy places, and a decline in the number of invocations of God, Jesus Christ, Virgin Mary, or various saints in wills at death, especially in Provence (Vovelle, 1973). In Brittany, evidence that such a change occurred is much more limited (Bois, 1960; Tingle, 2012), while Paris saw substantial heterogeneity, with parts experiencing a much larger decline in devotion than others (Chaunu, 1978).

In order to give an outline of the rest of the paper, I display religiosity across time (Panel A) and across space in 1791 (Panel A) with fertility across time (Panel B) and across space in 1851 (Panel D) in Figure 2-details are provided in Sections 3 and 4.2. Some regions, particularly Brittany, Paris, and Occitanie, were very religious, while other regions were

\footnotetext{
${ }^{10}$ Why dechristianization happened so early is a mystery. The austere morality imposed by the CounterReformation in France, its association with political and economic elites, the rigorism of Jansenists, and the religious competition between the Jansenists and Jesuits are believed to have precipitated social unrest and the decline in religiosity (Hoffman, 1984; Maire, 1998; Tackett, 1986; Van Kley, 1996). According to Hoffman (1984), "the Counter Reformation's austere morality was imposed in full force ... not surprisingly, it was rejected by people who saw nothing wrong in combining devotion and gaiety" (p. 138). Tackett (1986) evokes "epic struggles with the Jesuits" (p. 6) and argues that "a whole series of affaires and causes célèbres, from the repression of the convulsionnaries in the 1730's through the billets de confessions in the 1750's and the expulsion the Jesuits in the 1760's, had contributed in broadly publicizing and intensifying grievances toward the clergy." (p. 257). According to Braudel (1986b), "the drama played out in the 18th century was a sort of revenge on the part of the Reformation. Having hesitated, two centuries earlier, between Rome and Luther, or rather between Rome and Calvin, France had chosen Rome, but the choice backfired" (p. 200).
} 
much less religious in the late eighteenth century, an observation in line with historical and anecdotal evidence on dechristianization in Provence and Auverge-Rhône-Alpes (Hoffman, 1984; Norberg, 1985; Tingle, 2012; Vovelle, 1973). ${ }^{11}$

Figure 2: Religiosity and fertility

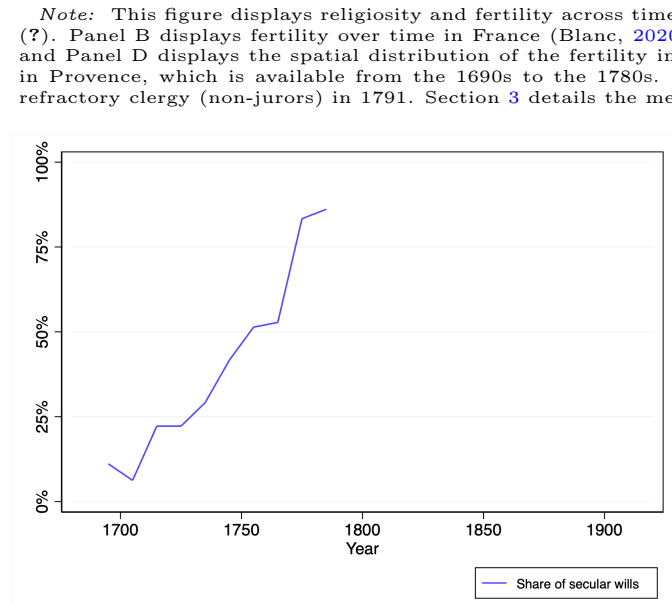

(Panel A) Secularization in Provence over time

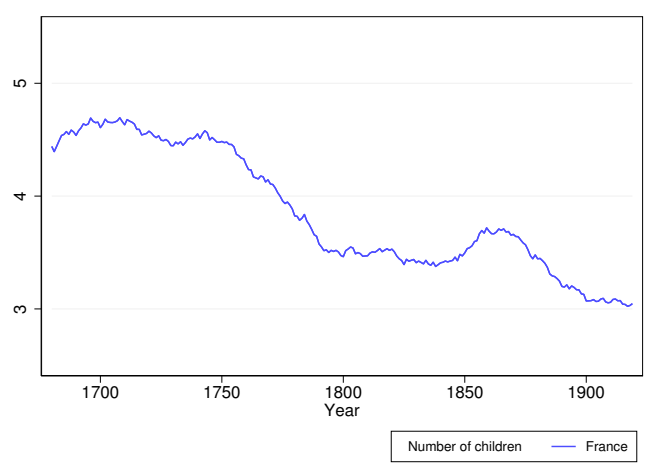

(Panel B) Fertility in France over time

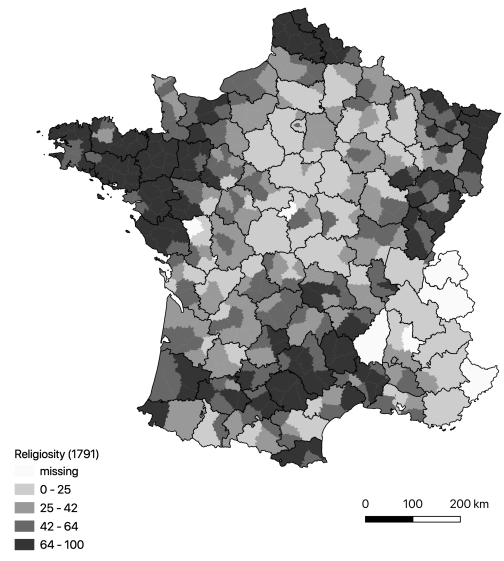

(Panel C) Religiosity (1791)

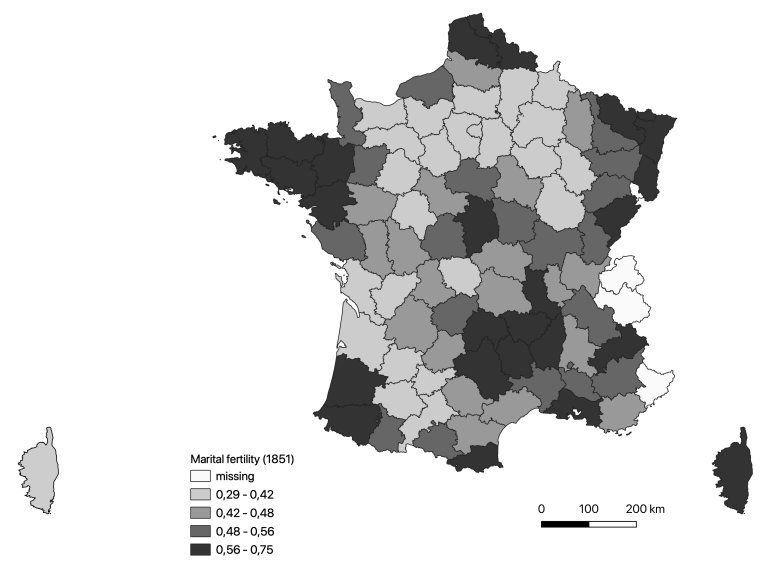

(Panel D) Marital fertility $I_{g}(1851)$

\section{DATA}

This section presents the main data sources and variables. The main explanatory variable is introduced in Section 3.1, and I present the dependent variables and controls at the

${ }^{11}$ Note that Savoy - which was not part of France - had a high level of marital fertility after 1851, when the data became available. This is consistent with the evidence presented by Chartier (1991) showing the absence of secularization there: "Habits thus seem to have been quite different on different sides of the frontier, which suggests the singularity of dechristianization in France" (p. 97). 
département level in 3.2 and at the individual level in 3.3.

Départements have been the main administrative units in France since 1790. All are of nearly equal size (about 2, 300 square miles) and designed to ensure that travel by horse from any location within the département to the main administrative center would not exceed one day. Districts are lower-level units about a third of the size of a US county, with close to no administrative purpose, and were created in 1790 with no more than 9 or less than 3 districts per département. They were replaced by and merged into (larger) arrondissements in 1795. In total, there are ninety départements and 513 districts. ${ }^{12}$

\subsection{Religiosity}

After secularization. The main explanatory variable throughout the paper is the share of refractory clergy in 1791 - after the bulk of secularization. ${ }^{13}$ In July 1790, during the French Revolution, the National Constituent Assembly passed the Civil Constitution of the Clergy, which required all clergymen to swear an oath of loyalty to the secular state. I use the share of clergymen that did not take the oath (known as refractory clergy or non-jurors) to proxy for religiosity in 1791. According to Tackett (1986), "The regional reactions of clergymen in 1791 can be revealing of the attitudes and religious options of the lay population with which the clergymen lived" (p. xvi). ${ }^{14}$

The oath has been commonly used in the literature as a proxy for religiosity in lateeighteenth-century France (Franck and Johnson, 2016; Squicciarini, 2020) and there is widespread evidence that the refractory clergy captured religiosity on the eve of the French Revolution remarkably well. According to Tackett (1986), "The map of clerical reactions in 1791 was remarkably similar to the map of religious practice in the middle of the twentieth century" (p. xv). In Sections 4.1 and 4.2, I also show that the presence of refractory clergy is highly correlated with religious practices and attitudes at the time of the decline of religiosity and in the nineteenth and twentieth centuries. For that reason, the population weighed share of refractory clergy in 1791 is henceforth referred to as religiosity in 1791, or Religiosity (1791), in the main tables and figures.

Importantly, the share of refractory clergy is measured before the August 1792 decree that ordered all non-jurors to leave the country and before the War in Vendée, the Paris Commune, the Reign of Terror, and the establishment of anticlerical cults (the Cult of Reason and the Cult of the Supreme Being, among others). Moreover, before the 1792 decree, according to Tackett (1986), "the National Assembly ... allowed the continued presence of the refractory clergy." Hence, the refractory clergy in 1791 does not capture the effect of the main revolutionary events and policies of dechristianization but rather religious

\footnotetext{
${ }^{12}$ For regions, I use the 2016 division of thirteen regions. I generate district boundaries with Thiessen polygons.

${ }^{13}$ Because the oath is measured at the district level, I use the district population-weighed average of the districtlevel share of refractory clergy in the analysis at the département level.

${ }^{14}$ The oath generated passionate reactions everywhere: "the issue of the oath soon became a veritable obsession, unleashing emotional reactions and factional strife in parishes everywhere" (Tackett, 1986, p. 4).
} 
attitudes right before the French Revolution. In order to account for state legitimacy at the time of the French Revolution, I control for the share of deserters among conscripts in the French army between 1798 and 1805 (Forrest, 1989). ${ }^{15}$

The data on oath-taking priests in 1791 are available at the département, diocese, and district levels and are constructed from the choices of more than fifty thousand parish clergymen, who made up more than 90 percent of all priests and vicars holding posts (Tackett, 1986, p. 39). At the district level, the share of non-oath-taking priests is almost uniformly distributed from 0 to 1 , while it varies from 8 to 91 percent at the département level, with an average of 48 percent.

Before secularization. Given the fact that the loss of influence on the part of the Roman Catholic Church took hold in France in the eighteenth century, showing that devotion has a positive impact on fertility should be sufficient to claim that dechristianization accounts for the decline in fertility. Yet in the paper I try to capture dechristianizationthe decline in religiosity. In particular, I leverage data on devotion in both time and space in Section 4.2 and find an important correlation of the change in devotion over time with religiosity in 1791, suggesting that the distribution of religiosity in 1791 is indeed the result of the process of secularization.

At the département level, I supplement the data on religiosity in 1791 with a set of controls aimed at capturing pre-existing differences in devotion, before secularization. The pre-secularization religiosity controls include the number of clergymen per capita in 1791, the average tithe in 1750, the number of abbeys in 1756, the duration of Jesuit presence before 1763, and finally the share of Protestants in 1815, after the revocation of the Edict of Nantes. ${ }^{16}$ The first three measures aim at capturing religiosity in the pre-1750 era. ${ }^{17}$ The prevalence of clergymen was particularly high, with one per five hundred inhabitants. Abbeys and monasteries played a significant role in local religious life (Heldring, Robinson and Vollmer, 2017) and are therefore included too. Finally, the average tithe is clearly a correlate of religiosity in a club-good model à la Iannaccone (1998). The last two measures are standard measures used to capture the presence of specific religious groups that may especially matter for upper-tail human capital - namely, Jesuits and Protestants. At the district level, I control for the number of abbeys and the duration of Jesuit presence and include dummies for their presence.

\footnotetext{
${ }^{15}$ Although there is no reason state legitimacy would have any impact on fertility. Because of that, I expect that the coefficient estimated from the regression of fertility on the share of refractory clergy will be the same as the coefficient on religiosity, irrespective of whether I control for proxies for state legitimacy.

${ }^{16}$ I do not include the 1670 measure of the share of Protestants (the only other available year) because it would not capture the effect of the revocation of the Edict of Nantes in 1685. Including the 1670 share of Protestants instead does not change the point estimates but increases standard errors because the number of observations is lower.

${ }^{17}$ Clergymen per capita is measured in 1791 , at the same time as the share of refractory clergymen is measured. However, this is a stock measure, and it is unlikely that the total number of clergymen would have immediately declined following the decline in religiosity (if it did, it would drive the coefficient on the share of refractory clergy to zero). Point estimates are larger in most regressions without adding this control.
} 


\subsection{Département level}

Marital fertility. The main dependent variable at the département level is the index of marital fertility, $I_{g}$. The index was constructed by Coale and Watkins (1986) as part of the Princeton European Fertility Project (PEFP), and it is available for about eighty départements. The PEFP provides data at the subnational level for all countries in Europe (in France, they are at the département level). ${ }^{18}$

The index $I_{g}$ measures the fertility of a population relative to the maximum that might be attained - that is, "how closely the married population approaches the maximum fertility it might experience" (Coale and Watkins, 1986, p. 161). It is constructed from the counts of the French census. It equals the total number of children born to married women divided by the number of children that would be born to these women had they not practiced any form of limitation (the denominator uses data from the Hutterites, an Anabaptist sect that does not practice any fertility control):

$$
\left(I_{g}\right)_{i}=\frac{B_{i}^{m}}{\sum_{j} M_{i j} G_{j}}
$$

$B_{i}^{m}$ is the total number of children born to married women in society $i, M_{i j}$ the number of married women in age cohort $j$, and $G_{j}$ the rate of fertility of Hutterites for age cohort $j$. I focus on marital fertility rather than overall fertility because it is the standard measure to detect the presence of fertility control achieved through parity-specific means (Coale and Watkins, 1986). Table A3.2.1, Panel A presents summary statistics for the index of marital fertility. The index is available for nineteen years (from 1831 to 1961) and decreases from 0.56 to 0.33 . Section 5 reports cross-sectional regressions for both the year of transition to a marital-fertility index below 50 percent and levels of marital fertility in 1851 and 1901 .

Controls. I supplement these data with a set of controls used in the départementlevel regressions in Section 5. Table A3.2.2 details these controls while Figure A3.2.1 displays the spatial distribution of some variables of interest. In addition to the proxies for religiosity before secularization, I also control for broadly defined cultural and institutional factors with a dummy that measures the presence of a printing press in 1500, the number of books printed in 1500, a dummy for the presence of a university before 1750 , Encyclopédie subscriptions per capita in the period 1776-79 (as a proxy for the diffusion of the Enlightenment), and linguistic distance from French in 1901. Institutional factors include dummies for pays status (fiscal regions inAncien Régime France, which may capture differences in culture or state capacity), and the share of deserters among conscripts in the French army between 1798 and 1805. I further control for education using the literacy rate of conscripts in the year of observation. Finally, in order to control for pre-industrial devel-

\footnotetext{
${ }^{18} \mathrm{~A}$ number of minor issues have been identified with the data from the PEFP, mainly with respect to the identification of the presence of fertility controls - see Brown and Guinnane (2007); Guinnane (2011). These issues are less relevant in this context since I study fertility levels after the transition already took place. 
opment, I include département-level population density (a standard proxy for development in the pre-industrial era - see Ashraf and Galor (2011)) and average soldier height before 1760. I control for contemporary development with the log rate of urbanization in the year of observation, defined as the share of the population living in towns with more than five thousand inhabitants.

\subsection{Individual level}

The département-level data are supplemented with a new individual-level dataset crowdsourced from publicly available genealogies. Blanc (2020) reconstructs rates of completed fertility (number of children born) at the individual level from family trees posted on the genealogical website geni.com and scraped by Kaplanis et al. (2018). The dataset contains thousands of individuals and is nationally representative of France from roughly 1680 to 1920 (while the département-level data are only available after 1831).

Lineage reconstruction from crowdsourced genealogies relies on the work of descendants reconstituting their family tree today by searching through the same parish records as the ones used by demographers. Parish records are available online with unrestricted access in all French départements from the mid-seventeenth century onward. However, family reconstitution requires a great deal of information on handwritten birth, marriage, and death records of often-dubious quality (Séguy, 2001). Tracing fertility requires knowing all the birth records of the children of an individual. Because of poor handwriting, individuals with same first names, imprecise information (rounded dates, changing names), and migration, it is a very tedious job with results that are often imprecise. Descendants have better incentives than demographers to thoroughly gather this information and have a knowledge of family history and past migrations that may help them in the process. This allows us to fully account for migration, to gather family trees more comprehensive than what demographers constructed, and to get a substantial degree of spatial variation, which demographers were not able to get because they worked one parish at a time.

An important caveat is that a significant number of observations in the sample might not have a recorded horizontal lineage, as individuals reconstituting their family tree today have a greater incentive to record their direct ancestors (the vertical lineage) than the horizontal branches. Following Blanc (2020), I deal with this issue by defining the fertility sample, the sample of individuals for which at least one parent in any of the four generations preceding the individual observation is recorded as having a fertility rate strictly greater than one. Finally, since the dataset does not always contain both spouses, I cluster all regressions at the couple level, thereby accounting for couples fully recorded, and use a male dummy in order to account for possible differences in gender.

Appendix Figure A3.3.2 provides the time series of fertility, urbanization, and mortality in the crowdsourced data (for individuals who lived in France during that period) and in representative data for France (using a combination of sources including censuses when 
available). There are no substantive differences, suggesting that selection into the sample is limited during that period of time (see Blanc (2020) for a detailed discussion). All observations contain geocoded places of birth, marriage, and death, which allows me to match individuals with Religiosity (1791) at the level of their district of birth. Figure A3.3.1 displays the towns of birth included in the fertility sample. Summary statistics for the 17, 358 individuals in the fertility sample are found in Table A3.3.1.

\section{Religiosity AND SECUlarizAtion}

Does the share of refractory clergy capture religiosity? Does it capture secularization or differences in religiosity that persisted through centuries? This section seeks to answer these questions. First, I evaluate the persistence of religious practice before and after secularization. I provide strong evidence suggesting that the share of refractory clergy captures religiosity in 1791 and that the distribution does not reflect pre-existing differences. Then I leverage detailed town-level data on religiosity in the region of Provence over time, throughout the eighteenth century, in order to show that religiosity in 1791 captures secularization rather than pre-existing differences. Finally, I discuss the correlation of religiosity in 1791 with development and provide suggestive evidence that poor places experienced stronger secularization.

\subsection{Persistence of religious practice}

After secularization. Is the share of refractory clergy capturing religiosity, and did it persist after secularization? There is mounting evidence that the answer to both of these questions is yes. Appendix Figure A4.1.1 displays the spatial distribution of measures of the intensity of religious beliefs in the nineteenth and twentieth centuries: a dummy variable that equals one if Catholic practice in a département was deemed 'good' by the local administration in 1877 (Gadille, 1967) or if a district was coded as Catholic in 1947 (Boulard, 1947), the share of Catholic schools in 1901 (SGF, 1901), average Easter attendance in 1966 (Boulard, 1966), and the share of baptized births in 2013 (Vaillant and Dufour, 2013). In contrast to the population-weighed share of refractory clergy in 1791, which may capture noise and the political legitimacy of the French Revolution, these variables are more direct (and the best available) measures of religious beliefs, although they are only available much later. I show that the population-weighed share of refractory clergy is highly correlated with these measures of religiosity in the nineteenth and twentieth centuries, which suggests that it does captures religiosity and that religiosity persisted over time. Similarly, Squicciarini (2020) shows that the share of refractory clergy in 1791 is highly correlated with the share of antireligious cahiers de doléances in 1789. For these reasons, I use the term religiosity in 1791 to denote the main independent variable.

Table 1 reports the results of the regressions of these measures on Religiosity (1791). 
In all specifications, I control for the share of deserters among conscripts in the French army between 1798 and 1805 (Forrest, 1989) in order to account for state legitimacy at the time of the French Revolution. I report standardized beta coefficients, or marginal effects for dummy variables, in order to assess the size of the correlation. In the first and third columns, I estimate (with a logit model) the marginal effect of the share of refractory clergy in 1791 on a dummy that equals one if Catholic practice was 'good' in 1877 or if the district was Catholic in 1947. The marginal effect is close to or higher than one in both cases, suggesting that having only refractory clergy in 1791 predicts full Catholic practice later on. In specification 2, I show that Religiosity (1791) is highly correlated with the share of Catholic schools in 1901. Specification 4 uses the best available measure of religiosity, Easter attendance in 1966 (Boulard, 1966). I find that a one-standard-deviation increase in Religiosity (1791) is predicted to increase Easter attendance by almost half a standard deviation. Finally, in specification 5, I find results similar in magnitude for the share of baptized births in 2013.

Table 1: Persistence of religious practice (after secularization)

\begin{tabular}{|c|c|c|c|c|c|}
\hline & $\begin{array}{l}\text { (1) Dummy=1 if 'good' } \\
\text { Catholic practice (1877) }\end{array}$ & $\begin{array}{l}\text { (2) Share Catholic } \\
\text { Schools (1901) }\end{array}$ & $\begin{array}{l}\text { (3) Dummy=1 if } \\
\text { Catholic (1947) }\end{array}$ & $\begin{array}{l}\text { (4) Average Easter } \\
\text { attendance (1966) }\end{array}$ & $\begin{array}{l}\text { (5) Share baptized } \\
\text { births (2013) }\end{array}$ \\
\hline & Logit & OLS & Logit & OLS & OLS \\
\hline \multicolumn{6}{|l|}{ Religiosity (1791) } \\
\hline Marginal effect & $\begin{array}{c}1.570^{* * *} \\
(0.197)\end{array}$ & & $\begin{array}{c}0.954^{* * *} \\
(0.106)\end{array}$ & & \\
\hline Standardized beta coefficient & & $\begin{array}{c}0.313^{* * *} * \\
(0.116)\end{array}$ & & $\begin{array}{c}0.466^{* * *} \\
(0.072)\end{array}$ & $\begin{array}{c}0.418^{* * *} \\
(0.108)\end{array}$ \\
\hline Observations & 80 & 82 & 503 & 503 & 92 \\
\hline$R^{2}$ & . & 0.14 & . & 0.23 & 0.18 \\
\hline
\end{tabular}

Before secularization. In order to understand whether religiosity persisted through dechristianization, Appendix Table A4.1.1 presents regressions of religiosity in 1791 on proxies for religiosity before secularization at the département and district levels. In specifications 1 to 5, the main independent variables are the number of clergymen per ten thousand inhabitants in 1791 (more details in footnote 17), the number of abbeys in 1756, average tithe rate in 1750, the duration of Jesuits' presence before their suppression in 1763, and the share of Protestants in the population in 1815, after the revocation of the Edict of Nantes. In specification 6, I include all of these variables.

Religiosity in 1791 does not correlate with any of these proxies for religiosity before secularization at the département level, which suggests that religiosity did not persist through dechristianization and that religiosity in 1791 does not capture pre-existing differences in religiosity. Yet some dimensions of religiosity seem to have persisted through seculariza- 
tion. ${ }^{19}$ At the district level, the duration of Jesuit presence has a positive and significant effect on religiosity after secularization. The magnitude of the effect is important since religiosity in 1791 was 13 percentage points higher in places where the Society of Jesus had settled for two centuries compared with those where it was absent. As many districts, especially the rural ones, did not have either Jesuits or abbeys, specification 8 adds dummy variables if either was present. I find that the presence of abbeys in 1756 also has an effect (significant at the 20 percent level) that seems to have persisted through secularization.

\subsection{Religiosity or secularization?}

The share of refractory clergy appears to capture religious devotion on the eve of the French Revolution, but is the cross-sectional distribution of religiosity in 1791 the result of a process that took place in the eighteenth century or does it simply reflect pre-existing differences? There is substantial evidence that the population-weighed refractory clergy does not capture pre-existing differences but the intensity of secularization. First, places where secularization was documented (Hoffman, 1984; Vovelle, 1973) also had a low share of refractory clergy in 1791. Second, as documented in the section above, proxies for religious beliefs before secularization largely do not correlate with religiosity in 1791. Although these are only proxies, the results indicate that religiosity in 1791 is not capturing pre-existing differences. Yet because of the lack of good data on beliefs or attitudes across time and space before secularization, there is no direct evidence - an issue I address with novel data in what follows.

Secular beliefs in the eighteenth century: evidence from Provence. In order to answer this question, I exploit detailed and never-before-used data on secular beliefs across time and space from the universe of wills at death in a comprehensive sample of villages and cities in about ten bailliages in four départements of Provence (Vovelle, 1973). ${ }^{20}$ Although wealthier individuals were slightly more likely to leave a will at death, they were written by individuals of all social classes and in some places by more than 80 percent of deceased adults. The use of attitudes towards death as an indicator of devotion goes back to Ariès (1974). In Provence, this is the only measure of the intensity of religious beliefs available across space both before and after secularization took place. For that reason, it is the best available account of secularization. Other measures such as church attendance or donations to the Church provide similar accounts but are available across either time or space, not both. ${ }^{21}$ The language used in the wills is an indication of the

\footnotetext{
${ }^{19}$ Consistent with what Squicciarini (2020) find when examining the role of historical plagues.

${ }^{20}$ The bailliage was an administrative unit roughly the size of a district or arrondissement before the French Revolution.

${ }^{21}$ For example, Vovelle (1973) finds a decline in requests for perpetual masses after one's death, from 90 percent of wills at the beginning of the eighteenth century to less than half before the French Revolution. Hoffman (1984) finds similar figures in the rural parts of the diocese of Lyon. However this measure is not available across space-which is important since I relate the secular wills to the refractory clergy below.
} 
intensity of the devotion of those who wrote them and changes radically over the course of the eighteenth century, when references to God, Jesus Christ, the Virgin Mary (who was particularly important in Provence), or various saints disappear and are replaced with secular language:

In the late seventeenth and early eighteenth centuries, testators consistently described themselves as adherent of the holy, apostolic Roman Catholic Church, who were prepared to meet their Maker, God the Creator, and Jesus Christ, His Son, by whose death and passion they hoped to be pardoned for their sins and to join the saints and angels in the Celestial Court of Paradise. ... By the 1780s most Provençal wills had reduced the traditional formula to a single clause: 'Having recommended his soul to God'. The Virgin Mary and saintly intercessors were gone, the Celestial Court emptied of angels. Christ himself had receded into the background, while God the Father sometimes took the form of 'Divine Providence'. Many wills had become totally secularized, and some even described death as 'the indispensable tribute that we owe to Nature'. (Darnton, 1978, p. 126)

Figure 3: Secularization in eighteenth-century Provence Note: This figure displays the median share of secular wills over time in Provence, from 1690 to 1789 . The share of secular
wills at the bailliage level is taken from and coded by Vovelle (1973).

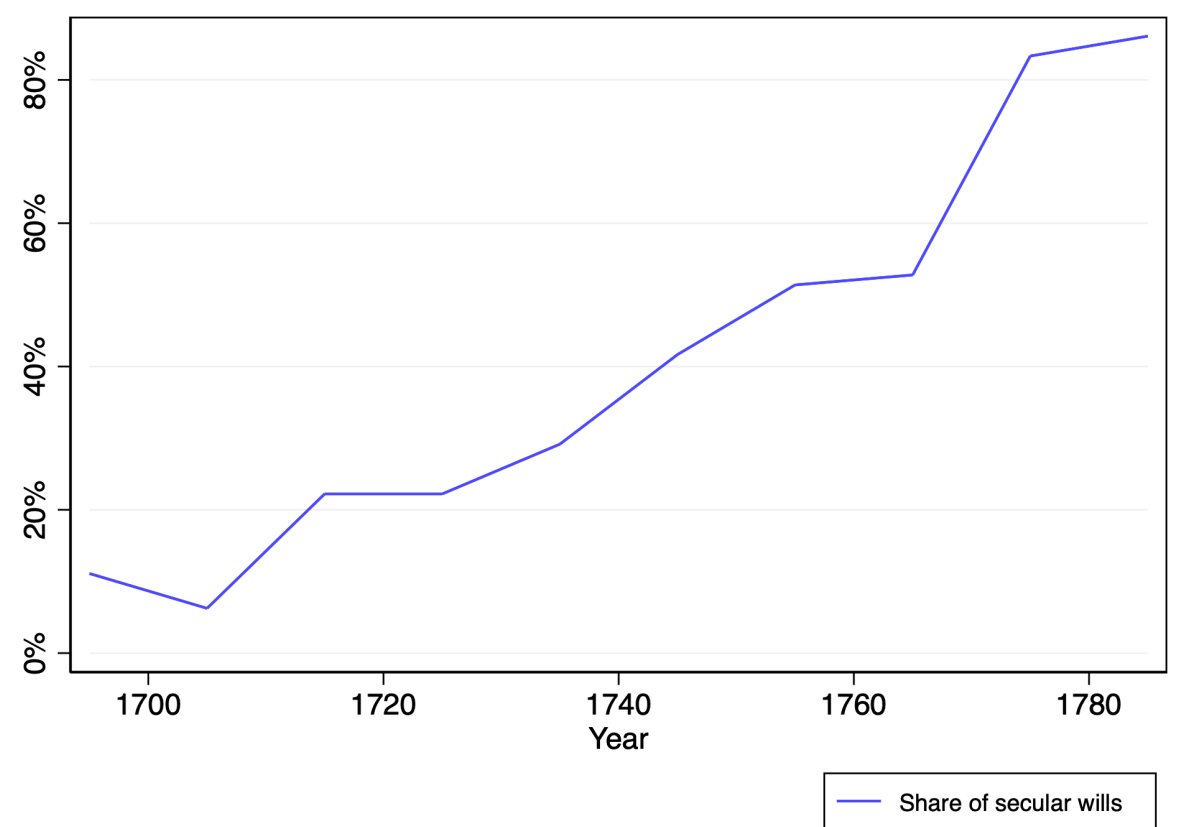

In order to grasp the magnitude and the timing of secularization, Figure 3 displays the share of secular wills in Provence over time as coded by Vovelle (1973). At the turn 
of the eighteenth century, only 13 percent of wills used secular language. ${ }^{22}$ Following the Great Plague of Marseille, which killed as many as 100, 000 people in the 1720s, the share of secular wills significantly decreased in places most affected by the plague. However this was only temporary. After the mid-eighteenth century, widespread secular changes in attitudes towards death took place with significant increases in the share of secular wills. Provence, which was one of the poorest, most rural départements, experienced dechristianization particularly early, before most of France (Vovelle, 1973).

On the eve of the French Revolution, more than 80 percent of wills were secular in Provence, while the population-weighed share of refractory clergy (religiosity in 1791) was 26 percent. Hence, to understand the drivers of the distribution of religiosity after secularization, I relate religiosity in 1791 to the extent of dechristianization in the cross-section as captured by the share of secular wills across time and space in Provence. The resultsespecially the standard errors - should be taken with a grain of salt because of the small size of the sample, but this is the best available data. In Figure 4, I plot the share of refractory clergy in 1791 against the share of secular wills in the 1690s and 1780s and against the change in the share of secular wills over time (Appendix Table A4.2.1 displays the results of the corresponding regressions). The data are available in seven bailliages for which the share of refractory clergy is also recorded: Aix-en-Provence, Arles, Brignoles, Draguignan, Forcalquier, Marseille, and Toulon.

Figure 4: Secularization and religiosity in 1791 in eighteenth-century Provence

Note: This figure displays the scatterplot of Religiosity (1791) on the share of secular wills in the 1690s in Panel A and on the share of secular wills in the 1780s in Panel B. Religiosity (1791) is defined as the population-weighed share of refractory clergy (non-jurors) in 1791. The share of secular wills at the bailliage level is taken from and coded by Vovelle (1973).

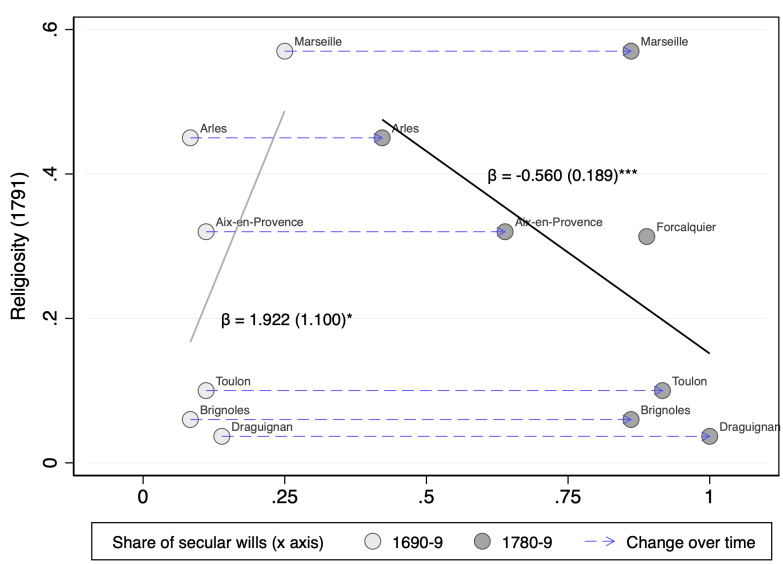

(Panel A) Secular wills (1690-1789) and refractory clergy

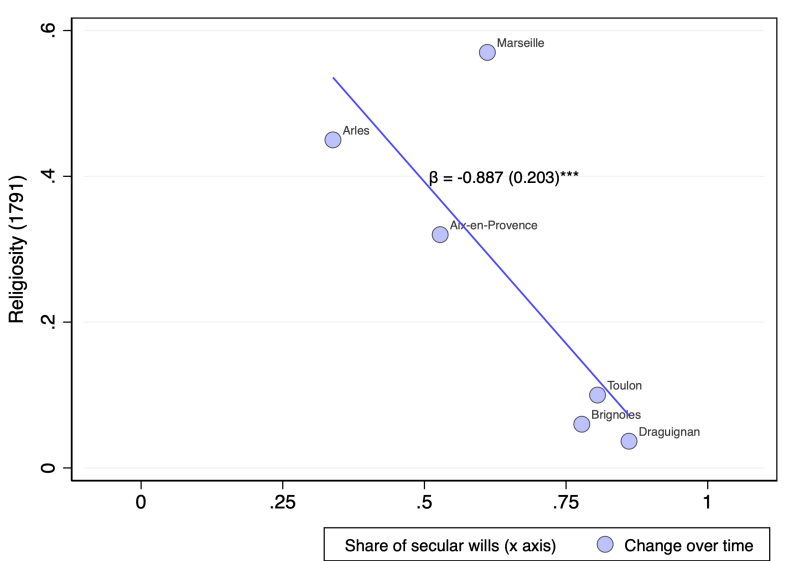

(Panel B) Secularization and refractory clergy

\footnotetext{
${ }^{22}$ This figure is likely overestimating secular beliefs before dechristianization since, as Vovelle (1973) argues, it is mostly the result of illiteracy or clergy members who deemed references to their faith too obvious (and are therefore coded as secular).
} 
In Panel A, I show that the share of secular wills in the 1780s is negatively correlated with religiosity in 1791, providing further evidence that the share of refractory clergy captures religiosity. However, before secularization, in the 1690s, religiosity was at near-maximal levels everywhere, with only about 13 percent of wills coded as secular in the 1690s and virtually no variation. I find that, if anything, the share of secular wills in the $1690 \mathrm{~s}$ is positively correlated with religiosity in 1791, suggesting that the most devoted places in the 1690 s experienced the strongest secularization. ${ }^{23}$ However, the result is not statistically significant at the 5 percent level and the regression line is essentially vertical. This is in line with the results at the département level and suggests that religiosity mostly did not persist through secularization.

In Panel B, I plot the refractory clergy in 1791 against secularization as captured by the change in the share of secular wills over time, from the 1690s to the 1780s. Despite the small sample, there is a clear negative and tight correlation between the two measures. An increase of the change in the share of secular beliefs of 100 percentage points is associated with a decrease in religiosity in 1791 of about 90 percentage points. ${ }^{24}$ In specification 5 of Appendix Table A4.2.1 I show that the share of secular wills in the 1780s, not only the refractory clergy in 1791, is associated with the increase in the share of secular wills in the eighteenth century and the relationship is almost one to one. This suggests that not only does the share of refractory clergy in 1791 capture religiosity, but it also mostly reflects dechristianization in the eighteenth century rather than pre-existing differences. ${ }^{25}$

\subsection{Religiosity and development in France}

How does religiosity in 1791 correlate with development at the time? In Appendix Table A4.3.1, I show that religiosity in 1791 is positively correlated with various proxies for development at the town level. In order to capture the correlation of secularization, rather than religiosity, with development, I also control for proxies for religiosity before secularization. Finally, I only report average marginal effects since the table only tests for the sign and statistical significance of the relationship.

I find a positive correlation of religiosity with log population in 1793 (the earliest available year) at the town level, a traditional proxy for development in the pre-industrial era (Ashraf and Galor, 2011). ${ }^{26}$ The results also hold for urbanization, estimated with logit. Next, I show that religiosity in 1791 is positively correlated with Encyclopédie subscriptions per capita at the district level. Hence, not only the size of the population is correlated with

\footnotetext{
${ }^{23}$ The results hold when comparing the share of secular wills in the 1690 s to the share of secular wills in the 1780 s, instead of the refractory clergy in 1791.

${ }^{24}$ If there is virtually no variation in religiosity before secularization within Provence, then it is logical to find that religiosity in 1791 fully captures secularization.

${ }^{25}$ In the bulk of my empirical analysis of fertility, I use region fixed effects and proxies for religiosity before secularization in order to account for regional-level unobserved pre-existing differences and to capture the small variation observed in the late seventeenth century.

${ }^{26}$ This is a stock variable, and it is unlikely to have been affected significantly by the decline in fertility.
} 
religiosity, but also its quality. Subscriptions to the Encyclopédie are a traditional proxy for the presence of knowledge elites or of the diffusion of the Enlightenment in France (Squicciarini and Voigtländer, 2015, 2016). The point estimate drops after controlling for religiosity before secularization, but that is likely because the controls at the district level include a dummy that equals one if there was a Jesuit school at some point in the past and the presence of Jesuits is highly correlated with subscriptions to the Encyclopédie (Sunde and Rosenberger, 2019). Finally, I find that the sign of the correlation is also positive for soldier height before 1760 (Komlos, 2006), also a traditional proxy for development.

The results indicate that secularization may have happened in poor and rural places first. This is surprising to the extent that the correlation between religiosity and development is usually believed to be negative (Barro and McCleary, 2003): wealthier places are less religious and traditional. However, this is consistent with what Hoffman (1984); Norberg (1985); Vovelle (1973) find in Provence and in the rural parts of the dioceses of Lyon and Grenoble. If anything, these results suggest that the effect of religiosity in 1791 on fertility is downward biased since urban places are also centers of innovation and human-capital accumulation.

\section{MAIN EMPIRICAL FINDINGS AT THE DÉPARTEMENT LEVEL}

\subsection{Baseline results}

Determinants of year of transition. In this section, I study the cross-sectional determinants of transition date. The main variable of interest is religiosity in 1791, while the dependent variable is defined as the first year of transition below a marital-fertility index of $50 \%$. I estimate Equation 1 with OLS and a Tobit model (by maximum likelihood) in order to account for the left-censoring nature of the data since about a quarter of départements had already transitioned in 1831.

$$
(\text { Transition date })_{i}=\beta \times \text { Religiosity }_{i, 1791}+\boldsymbol{X}_{i}^{\prime} \delta+\varepsilon_{i}
$$

Table 2 reports the results, along with robust standard errors. Appendix Figure A5.1.1 plots the scatterplot and partial residual plot. A 10-percentage-point increase in religiosity in 1791 is associated with a delay in the year of transition of more than ten years. This is a remarkably large effect: moving from the 25 th to the 75 th percentile of the distribution of religiosity predicts a delay in the demographic transition of about forty years.

The estimates are stable and significant at the 1 percent level across all specifications. Specification 2 controls for proxies for religiosity before secularization in order to capture the effect of secularization. These controls include, notably, the number of clergymen per capita, the number of abbeys, and the average rate of the tithe collected by the church. Speci-

fication 3 controls for observed cultural and institutional factors. In particular, the share 
Table 2: Determinants of transition date

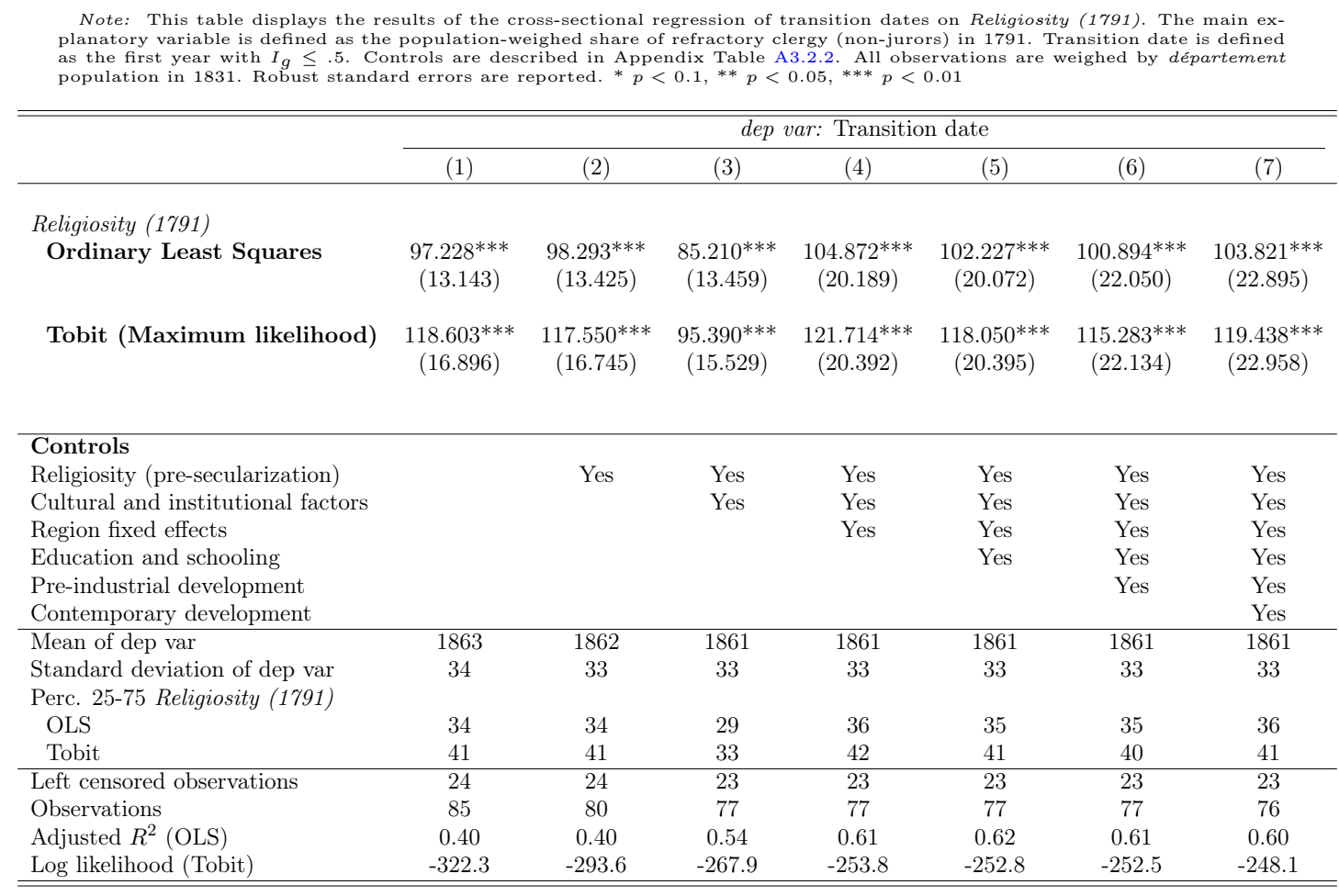

of deserters in the army during the French Revolution and fiscal status (pays d'élection, d'Etat, or d'imposition) in the Ancien Régime allow me to capture religiosity and not state legitimacy with the refractory-clergy measure. The specification also controls for linguistic distance to French (in order to capture the diffusion and adoption of new cultural norms (Spolaore and Wacziarg, 2019)) and Encyclopédie subscriptions (in order to capture the diffusion of the Enlightenment and the presence of local knowledge elites, who may have had an impact on cultural change and the modernization of society as a whole). Specification 4 adds twelve region fixed effects to account for unobserved cultural or economic factors that might confound the effect of religiosity in 1791. For example, ancestry may have an effect on the diffusion of modernization (Weber, 1976), while the presence of nuclear family structure might influence on fertility (Todd, 1990). ${ }^{27}$ Specification 5 controls for literacy to account for the quantity-quality trade-off, while specifications 6 and 7 account for development. The results remain virtually unaffected.

Finally, I estimate Equation 1 for alternative definitions of transition date in Appendix Table A5.1.1. The coefficient on religiosity is maximized for the first year in which marital fertility dropped below 0.6 , which corresponds to a 10 percent decline from the average level

\footnotetext{
${ }^{27}$ After including fixed effects for family structure, the estimated OLS coefficient drops to 95.19 (still significant at the one percent level). I do not report this in the table because of measurement and reverse causality (family structure is measured after the decline in religiosity and fertility), in order to limit the number of fixed effects, and for ease of interpretation.
} 
of marital fertility in pre-transition Europe - about 0.65, compared to 0.55 in France (Coale and Watkins, 1986) - with a 10 percent decline the criterion used to date the transition in Europe. A decline in marital fertility below 0.5 corresponds to a drop of about 25 percentthis is the main specification because it has the least censored observations.

Magnitude and relative importance. I assess the relative magnitude of potential (prior) determinants of transition date, including religiosity, and the robustness of the estimated effects to the inclusion of controls. Table 3 presents standardized beta coefficients for these selected determinants of transition date, both without any control and with the full set of controls - corresponding to the main specification of Table 2. In the first specification, no controls are included and each cell represents the result of a different regression and reports standardized beta coefficient of the variable of interest in the left column. In the second specification, the full set of controls (including religiosity in 1791) are included.

Table 3: Magnitude and importance of the determinants of transition date

\begin{tabular}{|c|c|c|}
\hline \multirow[b]{2}{*}{$\begin{array}{l}\text { Specification in columns, each cell reports result } \\
\text { of a different regression w/ var of interest below: }\end{array}$} & \multicolumn{2}{|c|}{ dep var: Transition date } \\
\hline & (1) No controls & $\begin{array}{l}\text { (2) Full set } \\
\text { of controls }\end{array}$ \\
\hline \multicolumn{3}{|l|}{ Standardized beta coefficients } \\
\hline Religiosity (1791) & $0.64^{* * *}$ & $0.69 * * *$ \\
\hline $\log 1+$ Encyclopedie per 10,000 inhab. (1777-79) & $-0.28 * * *$ & $-0.31^{* *}$ \\
\hline Linguistic distance to French (1900) & $0.15^{+}$ & 0.09 \\
\hline Literacy $(1831)$ & -0.13 & $0.31^{+}$ \\
\hline Population density (1831) & -0.03 & -0.10 \\
\hline Urbanization (1831) & -0.03 & -0.11 \\
\hline
\end{tabular}

As a first step, I evaluate the role of cultural attributes and find a large and significant correlation with subscriptions to Diderot and d'Alembert's Encyclopédie. Decreasing the number of subscriptions per capita by one standard deviation is predicted to delay the transition date by one-third of a standard deviation, with or without controls. This is the second-largest effect after religiosity in 1791 and is consistent with the pattern documented by Squicciarini and Voigtländer $(2015,2016)$. Yet it is unlikely that it played a major role in the French demographic transition because Enlightenment ideas diffused throughout most of Western Europe and especially England and Scotland. One possibility is that it accelerated the effect of, or enabled, secularization. For example, one could imagine that in places with many subscriptions, the libertine literature diffused to the general population in such a way that it triggered a decline in rates of fertility. I test this idea by interacting religiosity in 1791 with Encyclopédie subscriptions, but I find no significant effect (results are available upon request). 
Moreover, it could be the case that religiosity in 1791 captures not only the direct effect of cultural differences but also barriers to the diffusion of norms favoring limited fertility. In order to understand the role of diffusion, I look at the size of the effect of linguistic distance from standard French in $1900 .^{28}$ The effect is important but only statistically significant at the 20 percent level, and it is more than four times smaller than the effect of religiosity in 1791, suggesting that the main independent variable is capturing a direct effect of religiosity rather than barriers. Finally, neither literacy, nor population density, nor urbanization had a significant or large effect on the timing of transition.

Determinants of marital fertility. Finally, I estimate the cross-sectional determinants of $I_{g}$ from 1831 to 1901 with Equation 2 using OLS.

$$
\left(I_{g}\right)_{i, t}=\beta_{t} \times \text { Religiosity }{ }_{i, 1791}+\boldsymbol{X}_{i, t}^{\prime} \delta_{t}+\varepsilon_{i, t}
$$

Appendix Table A5.1.2 reports the results for 1851 (the first year with Paris in the data) and 1901, along with robust standard errors. A 10-percentage-point decrease in Religiosity (1791) is associated with a decrease in the marital-fertility index of about 3 percentage points. The marital-fertility index in France averaged 0.49 in 1851, about half the Hutterite standard. The Table also reports standardized coefficients: throughout specifications, increasing Religiosity (1791) from the 25th to the 75th percentile of the distribution is predicted to increase $I_{g}$ by about 10 percentage points, slightly less than a standard deviation.

Appendix Figure A5.1.2 displays the standardized beta coefficients over time - as in Table 3-allowing for a more detailed analysis. Without controls, urbanization and population density first had a positive or null effect on the level of fertility and the effect became negative as time passed, somewhat consistent with a Malthusian mechanism or with the idea that overpopulation led to lower fertility in the nineteenth century (Braudel, 1986a,b). For literacy, I find a pattern consistent with a quantity-quality trade-off: at first, the correlation between fertility and literacy is positive; then it becomes negative.

\subsection{Alternative explanations and robustness: lasso estimation and sensitivity analysis}

Sensitivity of estimates and coefficient bounds. The set of seventeen control variables presented in Table A3.2.2 was gathered through an extensive process of data collection and accounts for a large number of cultural, economic, and institutional factors. Yet only a particular choice of covariates could be accounted for in the specifications under study, and collinearity or omitted variables could be introduced, which would result in biased and distorted coefficients (Brodeur et al., 2016; Brodeur, Cook and Heyes, 2020a;

\footnotetext{
${ }^{28}$ Similar to what Spolaore and Wacziarg (2019) test in Europe, but I use data from the Atlas Linguistique de la France (Blanc and Kubo, 2020) in order to get more granular variation in linguistic distance within linguistic areas.
} 
Granger and Uhlig, 1990; Leamer, 1983; Leamer and Leonard, 1983).

In order to assess the fragility of coefficients and to estimate bounds on the parameters of interest, I evaluate the robustness of the association of transition date with religiosity in 1791 across all 131, $072\left(2^{17}\right)$ combinations of controls. Appendix Figure A5.2.1 plots the distribution of estimated coefficients (and robust t-statistics) on Religiosity (1791) across all combinations of controls when region and pays-status fixed effects are included. ${ }^{29}$ Panels $\mathrm{A}$ and $\mathrm{B}$ plot raw distributions, while Panels $\mathrm{C}$ and D plot effect size and robust t-statistic by number of controls. Across all combinations, the mean estimated coefficient is 105.53 years, and no specification returns a coefficient for the marginal effect of religiosity in 1791 below 85 years. If anything, the more controls are added the higher the estimated effect is, consistent with the expectation that the results are downwards biased because of the positive correlation between religiosity and development.

Double lasso estimation and variable selection. Since the number of potential variables of interest is large and the determinants of both the decline in fertility and dechristianization are not well understood, I use lasso, a supervised machine-learning technique. Its purpose is threefold. First, it allows me to flexibly select important covariates of religiosity in 1791 in order to account for pre-existing differences. Second, it selects covariates of the timing of the demographic transition in a context where the decline in fertility cannot be explained by traditional theories. Third, it allows me to understand the robustness of the estimated effects and the relevance of specific predictors by shrinking the regression coefficients to zero.

The least absolute shrinkage and selection operator (lasso) is a regularization and variable selection method introduced by Tibshirani (1996). Lasso is essentially an $\ell_{1}$-penalized least squares estimate in which coefficients are estimated by minimizing the sum of squared residuals, as in OLS, but a shrinking process is also applied in order to penalize some of the variables by down weighing their coefficients toward zero. A tuning parameter $\lambda$ controls the strength of the penalty and is chosen by $k$-fold cross-validation by finding the lambda with the smallest average mean squared error in all out-of-sample predictions.

The determinants of transition date are estimated in Appendix Table A5.2.1 with the double-selection lasso estimation method described in Belloni, Chernozhukov and Hansen (2013); Urminsky, Hansen and Chernozhukov (2019). This two-step procedure identifies covariates that predict both the dependent and the independent variable. The variables selected in both steps are included in the final regression. This method alleviates biases commonly associated with lasso to the extent that excluding variables with moderate but non-null effects results in omitted-variable bias. In the first column, I report the unweighed OLS coefficient on religiosity in 1791 with the full set of controls. ${ }^{30}$ Specifications 2 to

\footnotetext{
${ }^{29}$ There are 32, $768\left(2^{15}\right)$ such regressions, with region and pays-status fixed effects. Alternatively, Figure A5.2.2 provides the results with all combinations of seventeen controls (including fixed effects). The results are unchanged.

${ }^{30}$ Because weighing creates significant issues with lasso, observations are not weighed by population. Therefore, 
5 display the double lasso-estimated coefficients. In specifications 3 and 5 , in light of the standardized coefficients estimated in Table 3, I force the selection of Encyclopédie subscriptions per capita by not penalizing its coefficient. In specifications 4 and 5 , I force the selection of fixed effects, otherwise not included in the set of controls. Without including the region and pays-status fixed effects, no variable other than religiosity in 1791 is selected by default. Moreover, the variables selected with fixed effects mostly capture cultural traits. Last but not least, the share of deserters among conscripts, which controls for state legitimacy at the time of the French Revolution in order to capture the effect of religiosity, is selected - which is reassuring. The estimated coefficient on religiosity in 1791 remains particularly large while, as predicted, lasso reduces variance.

Appendix Figure A5.2.3 plots the coefficient paths for the two lassos with fixed effects. The size of each of the coefficients is plotted against the penalty term $\lambda$. When lambda equals zero, lasso is equivalent to OLS; and all coefficients gradually shrink to zero as it increases. Only limited regularization is needed for the determinants of religiosity in 1791, suggesting that few observables explain its distribution with a large or robust effect when region and pays-status fixed effects are included. This is consistent with the evidence on Provence suggesting that there were only small differences in religiosity before secularization within region. As expected, the variable with the largest predictive power is the share of deserters among conscripts - validating its inclusion as control to account for institutional factors related to the French Revolution. Yet although none of the controls seem to matter for the distribution of religiosity, religiosity in 1791 itself has a large and robust predictive power for transition date (and, consistent with the standardized beta coefficients estimated previously, so does Encyclopédie subscriptions).

\subsection{Accounting for omitted variables and spatial dependance}

Omitted variables. While reverse causality is not an issue, omitted variables may result in bias. Religious areas may place more emphasis on tradition and be less prone to innovation and change, which would bias estimates and be a threat to identification. In what follows, I formally account for unobservables and rely on Altonji, Elder and Taber (2005); Oster (2016) to construct bounds to the true effect of religiosity in 1791. Because religiosity in 1791 is positively correlated with development after secularization took place (Section 4.3), estimates are expected to be downward biased toward zero.

I estimate a coefficient on religiosity accounting for omitted variables under the assumption of equal selection suggested by Altonji, Elder and Taber (2005); Oster (2016) - that is, that unobservables and observables are equally related to the treatment. ${ }^{31}$ Through-

the result in specification 1 can be compared to the result in specification 7 of Table 2 , where observations are weighed by population.

${ }^{31}$ Oster (2016) shows that movements in the $R^{2}$, and not only coefficient movements, can give information about the direction and the size of the bias arising from omitted variables. The $\beta^{*}\left(R_{\max }^{2}, \delta\right)$ statistics proposed by Oster (2016), with $\delta$ the degree of proportionality between selection on unobservables and observables, converges in prob- 
out this section, I alternatively make the two following assumptions about selection on unobservables: unobservable selection is exactly proportional to selection on observables (Assumption A); unobservable selection is exactly proportional to selection on the diffusion of the Age of Enlightenment (as proxied by $\log 1+$ Encyclopédie subscriptions per capita in the period 1777-79) conditional on other observables (Assumption B).

The first assumption is fairly standard, while assumption ?? relies on the idea that one can learn about unobservables that explain marital fertility from unobservable determinants of Encyclopédie subscriptions per capita, a standard measure to proxy for the diffusion of the Age of Enlightenment (Darnton, 1973; Squicciarini and Voigtländer, 2015). Using this proxy for a different dimension of cultural change allows us to sensibly model unobservables that may have affected marital fertility. Intuitively, although this is an oversimplification, I assume that the Age of Enlightenment affected marital fertility through unobserved factors (for example, libertinage, emphasis on change as opposed to tradition, industrial mindset) that are also correlated with secularization.

Appendix Table A5.3.1 report the results of the regression on the determinants of transition year accounting for unobservable selection. Panel A relies on Assumption ?? and Panel B on Assumption ??, which is the main assumption. In both cases I report both Oster's beta, assuming a degree of proportionality of one, and the $\delta$ statistics, which reflect how strong selection on unobservables should be to explain away the estimated effect of religiosity in 1791. Standard errors bootstrapped over one thousand replications are reported. Results are virtually unaffected by selection on unobservables, and if anything the estimated coefficients under the equal-selection assumption are larger than under OLS. In most specifications, selection on unobservables would have to be between 2 and 120 times as strong as selection on observables to drive the estimates to zero.

Finally, Appendix Figure A5.3.1 plots the effect of religiosity in 1791 over time after accounting for omitted variables. Panel A displays the estimated coefficients (OLS and omitted-variable-adjusted coefficient) for Religiosity (1791) from 1831 to 1901. OLS coefficients are biased downward throughout. Unobserved factors, such as a scientific and industrial mindset and less emphasis on tradition, were likely to play an observable role in the course of development as income per capita took off and the second phase of the demographic transition started, which could explain why the negative bias of OLS is more important after the 1870s. Panel B displays the marital-fertility index for France and for England and Wales over time, along with a counterfactual index for France, which is imputed by setting religiosity in 1791 to the maximal level (if no clergymen took the oath of allegiance to the secular state) under the coefficient bounds suggested by Oster. Religiosity in 1791 accounts for the majority of the difference between France and England and Wales.

ability to the true coefficient. If 0 does not lie in the interval between the OLS coefficient and $\beta^{*}\left(R_{\max }^{2}, 1\right)($ Oster's beta), then one can reject the null that the coefficient of interest is exclusively driven by unobservables. Following Oster (2016), I set $R_{\max }^{2}$ to $\min \left\{1.3 R^{2}, .9\right\}$ because of measurement error due to the historical nature of the data. 
Spatial dependence. The spatial distribution of religiosity in 1791 and marital fertility is geographically clustered. Although cultural attributes are often spatially clustered, this could lead one to interpret the results as strong and robust, but the interpretation would be erroneous since nearby places are naturally more likely to possess the same attributes. It is possible to account for spatial dependence by reporting adjusted standard errors (Colella et al., 2019; Conley, 1999). Yet Kelly (2019) shows that Conley standard errors are often too small because of low cutoff values, the distance beyond which spatial correlation is assumed to vanish. As a consequence, spatial noise with the same spatialcorrelation structure as that in the data can significantly outperform the results, which is highly problematic. I implement the solutions suggested by Kelly (2019) and report Conley standard errors for two different correlation ranges of 250 kilometers (Assumption 1) or 500 kilometers (Assumption 2). Then, I report the p-value of Moran's test for spatial dependence of OLS residuals, a standard spatial-correlation statistic. Last, I report the results of simulations where the dependent and independent variables are alternatively replaced by spatial noise. I run one thousand independent simulations each time and report the fraction of regressions significant at the 0.1 percent level.

Appendix Table A5.3.2 displays the results. Panel A provides the outcome of the simulations and tests for spatial correlation. Moran's statistic is significant (with $p<0.01$ ) in the first three specifications and for both ranges, suggesting a high degree of spatial correlation. Spatial noise significantly explains marital fertility at the 0.1 percent level in less than 10 percent of simulations. Panel B displays the estimated coefficient on religiosity in 1791 (as in Table 2) and spatial-correlation-adjusted standard errors. In the first specification, the standard error increases as the correlation range increases. However, the results remain highly significant. After the inclusion of fixed effects in specifications 3 and 4 to account for regional-level unobserved cultural and institutional factors, the p-value of Moran's test significantly increases and I fail to reject the null that errors are randomly distributed across the landscape. With fixed effects, less than 1 percent of simulations return significant results, and Conley standard errors become smaller than non-adjusted standard errors: accounting for spatial dependence with fixed effects significantly improves the precision of the estimation (Case, 1991). These results suggest that the effect of religiosity on marital fertility is not spurious and cannot be explained by simply fitting spatial noise.

\section{INDIVIDUAL-LEVEL RESULTS}

In this section, I turn to individual-level analysis using crowdsourced genealogies. I relate the fertility decisions of ordinary individuals in the past to attributes of their place of birth. This is the first research to leverage spatial variation at the time of the decline in fertility in France. Section 6.1 presents the baseline results, while Section 6.2 attains causal estimates of the role of dechristianization in the decline in fertility. 


\subsection{Baseline results}

Empirical strategy. I model the fertility decision of individual $i$ in Equation 3, where fert $_{i, t}$ is the completed fertility of individual $i$ in decade $t$. I exploit cross-sectional variation in fertility with decade fixed effects $\lambda_{t}$. Each individual is assigned the level of religiosity in 1791 of her district of birth $b(i)$.

$$
\begin{aligned}
& \log \lambda_{i, t}=\beta \times \text { Religiosity }_{b(i), 1791}+\boldsymbol{X}_{i, t}^{\prime} \delta+\lambda_{i}+\lambda_{t} \equiv \boldsymbol{z}_{i, t}^{\prime} \gamma \\
& \text { with } \text { fert }_{i, t} \sim \mathcal{P}\left(\lambda_{i, t}\right) \text { and } \lambda_{i, t}=\lambda\left(\boldsymbol{z}_{i, t}\right) \equiv \mathbb{E}\left(\text { fert }_{i, t} \mid \boldsymbol{z}_{i, t}\right)
\end{aligned}
$$

In order to account for the count nature of the dependent variable, I use a Poisson-model framework. In particular, I assume that fertility follows a Poisson distribution and that the $\log$ of the conditional mean of fertility is a linear function of observables. Equation 3 is therefore estimated with maximum likelihood as a Poisson regression in the bulk of the analysis, but the results are robust to using OLS or other estimation methods to account for overdispersion and heterogeneity in count outcomes such as negative-binomial regressions.

Main results. Table 4 presents the baseline results at the individual level for observations after 1760, when dechristianization and the decline in fertility started. The estimated coefficient is particularly large and stable throughout specifications, with the marginal effect of religiosity in 1791 on fertility estimated to be about one. This means that individuals born in a place with only refractory clergymen are predicted to have about one more child than those born in a place without any. This is roughly the size of the decline in fertility during the second half of the eighteenth century, when the number of children ever born went from 4.5 to 3.5 in about forty years (Figure 1).

All specifications include a male dummy and decade fixed effects. Standard errors are twoway clustered at the district-of-birth and couple levels. ${ }^{32}$ In specification 2, individual-level controls are included with a quadratic in the age at birth of the first child interacted with the male dummy: the reduction in fertility was not achieved by delayed age of marriage. ${ }^{33}$ Specification 3 adds proxies for religiosity before secularization at the district level: the presence (dummy) and number of abbeys in 1756, and the presence (dummy) and duration of Jesuit presence before 1763. In the last column, I control for a (time varying) dummy capturing the urban status of the town of birth at the time and I control for the presence (dummy) and number of knowledge elites by using Encyclopédie subscriptions at the district level. ${ }^{34}$ The results are statistically significant and stable throughout.

\footnotetext{
${ }^{32}$ Indeed, information about both parents is not always available. Therefore only about 10 percent of individuals have spouses also included in the regressions.

${ }^{33}$ Appendix Figure A6.1.1 plots the average timespan between the births of the first and last child (Panel A) and average duration between births of children (Panel B). Lower fertility was indeed achieved mostly through parityspecific controls: there is no significant change in duration, and age of marriage only increases slightly. A previous version of the paper also included the log fertility of parents. Estimates were smaller because the fertility of parents is obviously collinear with religiosity in 1791 for non-migrants.

${ }^{34}$ It is also possible to control for soldier height before 1760, at the town-of-birth level, as a proxy for development:
} 
Table 4: Determinants of fertility at the individual level

\begin{tabular}{|c|c|c|c|c|}
\hline \multicolumn{5}{|c|}{ 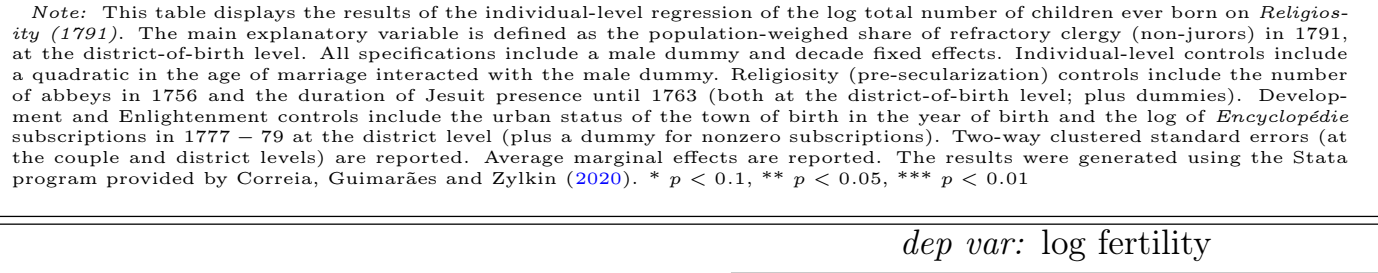 } \\
\hline & $(1)$ & $(2)$ & $(3)$ & $(4)$ \\
\hline Religiosity (1791) & $\begin{array}{c}0.252^{* * *} \\
(0.083)\end{array}$ & $\begin{array}{c}0.297^{* * *} \\
(0.084)\end{array}$ & $\begin{array}{c}0.281^{* * *} \\
(0.090)\end{array}$ & $\begin{array}{c}0.274^{* * *} \\
(0.088)\end{array}$ \\
\hline Marginal effect of religiosity on fertility & $0.893^{* * *}$ & $1.055^{* * *}$ & $0.997^{* * *}$ & $0.971^{* * *}$ \\
\hline \multicolumn{5}{|l|}{ Controls } \\
\hline Individual-level & & Yes & Yes & Yes \\
\hline Religiosity (pre-secularization) & & & Yes & Yes \\
\hline Cultural factors and development & & & & Yes \\
\hline Observations & 11,887 & 11,728 & 11,728 & 11,649 \\
\hline Clusters (couples) & 10,358 & 10,228 & 10,228 & 10,155 \\
\hline Clusters (districts) & 440 & 440 & 440 & 438 \\
\hline Pseudo $R^{2}$ & 0.01 & 0.06 & 0.06 & 0.06 \\
\hline
\end{tabular}

Robustness to method of estimation. Poisson regressions are appropriate for non-negative count dependent variables, yet they rely on the assumption of equality of the mean and variance. That said, the fact that the Poisson distribution is specified by only one parameter is attractive to the extent that, in the post-Malthusian period, it is likely that there was less variance as the mean fertility declined. ${ }^{35}$ As a result, the standard error of the estimated coefficient may be too small and significance could be overestimated. Hence, in order to evaluate the robustness of the results and to account for overdispersion, Appendix Table A6.1.1 estimates Equation 3 with OLS, overdispersed Poisson, and negative-binomial regressions. Results are practically unchanged. In overdispersed Poisson, the conditional variance is scaled by a parameter $\phi \equiv \chi_{\text {Pearson }}^{2} / p$ in order to directly account for the observed overdispersion. In negative-binomial regression, heterogeneity among individuals is accounted for by assuming that the outcome follows a negative-binomial distribution, hence adding variability that Poisson regression does not allow for.

this increases the point estimate of religiosity in 1791 but decreases the number of observations by one-third; hence the result is not reported here. Similarly, I can control for age at death since adult longevity may confound the effect of religiosity on fertility. Yet evidence suggests that religiosity declines with age (Lechler and Sunde, 2020), which would bias the estimates of the impact of religiosity on fertility downward. When I include age at death (which also results in a significant drop in the number of observations), point estimates are virtually unaffected. Results are available upon request.

${ }^{35}$ For example, see Spolaore and Wacziarg (2019). 
Distribution regression. Is the effect of higher religiosity uniform at all levels of fertility? I run a distribution regression in order to trace out the effect of religiosity in 1791 on the cumulative distribution function (CDF) of fertility, following Chernozhukov, Fernández-Val and Melly (2013). ${ }^{36}$ This method allows to estimate the entire conditional distribution, and, importantly, it does not require the outcome to have a smooth conditional density as in quantile regressions. Therefore it is more adapted to the study of fertility, which is a discrete outcome. I evaluate the effect of Religiosity (1791) on the cumulative distribution of fertility for all observed levels, and I estimate Equation 4 with OLS, where $\mathbb{1}_{\text {fert }_{i, t} \leq f}$ is a dummy that equals one if individual $i$ had less than $f$ children.

$$
\mathbb{1}_{\text {fert }_{i, t} \leq f}=\beta_{f} \times \text { Religiosity }_{b(i), 1791}+\boldsymbol{X}_{i, t}^{\prime} \delta+\lambda_{i}+\lambda_{t}+\epsilon_{i, t}
$$

Figure 5: Effect of religiosity in 1791 on the cumulative distribution of fertility

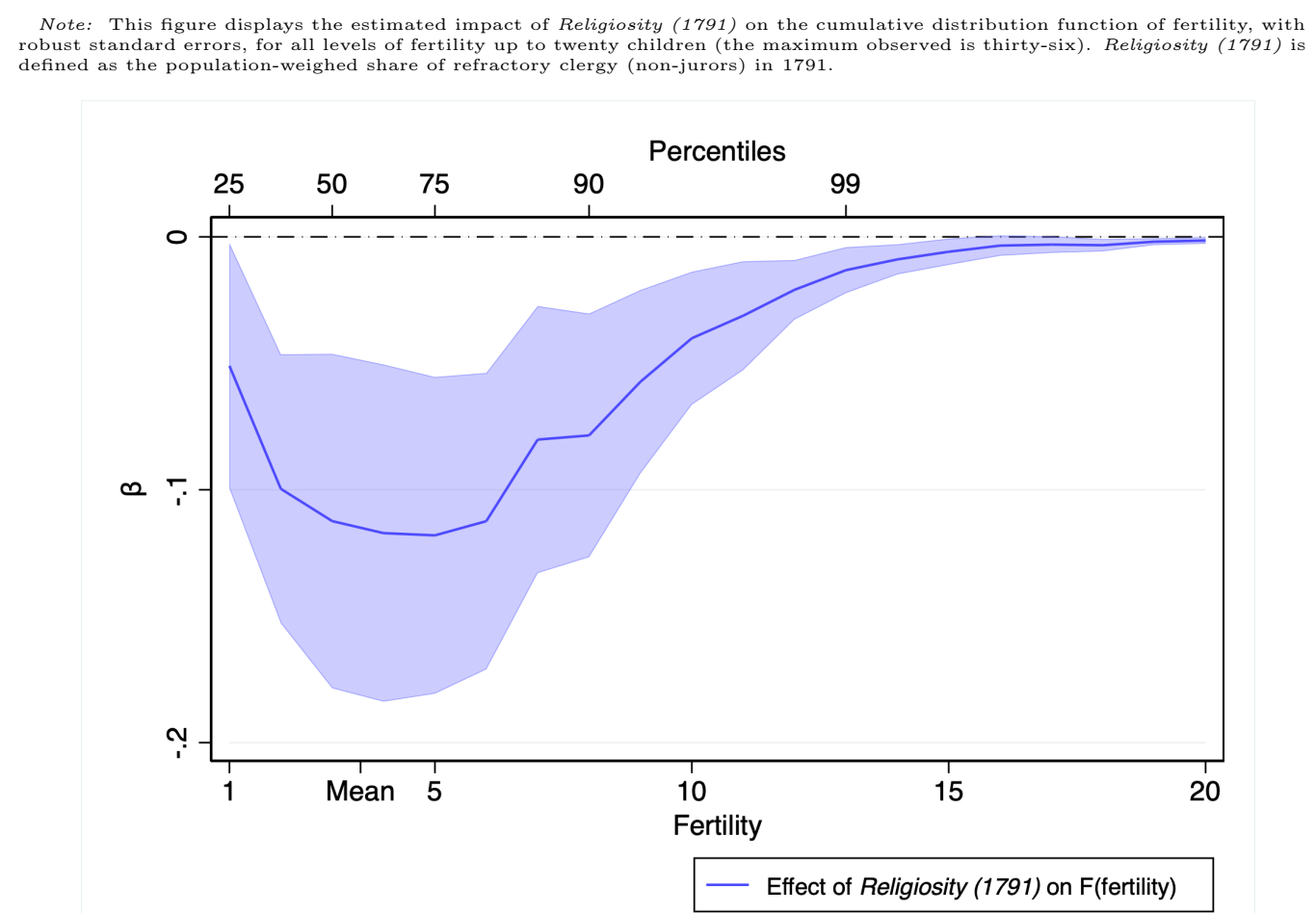

Figure 5 plots the results at different levels of fertility. The effect of religiosity in 1791 on the cumulative distribution is negative everywhere and is the most important for large families with fertility above the mean and median. Especially, increasing religiosity by 100 percentage points is predicted to increase the probability of having more than six children

\footnotetext{
${ }^{36}$ A thoughtful implementation of this methodology is provided by Goodman-Bacon (2016).
} 
by about 12 percentage points. ${ }^{37}$ Finally, a property of distribution regressions is that the estimated coefficients on the CDF (with the linear-probability model) sum up to the OLS coefficient of the effect of religiosity in 1791 on fertility in Appendix Table A6.1.1. ${ }^{38}$ Hence, it fully characterizes the average effect of religiosity in 1791 on fertility.

\subsection{Identification of a causal effect: fixed effects, difference-in-differences, and second-generation migrants}

The crowdsourced genealogical data allow me to employ three different strategies in order to identify a plausibly causal effect. To the best of my knowledge, this is the first time any of these strategies has been used in a historical context or with individual-level data in France or elsewhere.

First, it is possible to study within-département variation using fixed effects. In particular, département-by-decade fixed effects account for time-invariant and time-varying unobservables at the département level. This is particularly important to the extent that départements are the main administrative units, hence exploiting within-département variation allows to account for most institutional differences. For example, some départements may have been more affected by the French Revolution than others (for example, during the War in the Vendée or during the Reign of Terror), or the crowdsourced data may be of higher quality in some periods in some départements (since the records are kept in the online départemental archives), which could result in bias. ${ }^{39}$

Second, by extending the sample to individuals observed before dechristianization took place, it is possible to contrast the effect of religiosity in 1791 before and after secularization using a difference-in-differences framework with continuous treatment, similar to Acemoglu, Autor and Lyle (2004). ${ }^{40}$ The causal effect of religiosity on fertility can be identified by differencing its effect after secularization from its effect before using 1760 as the cutoff for the onset of secularization (also the start of the decline in fertility). Unfortunately, the exact date is an unknown parameter (although there is a consensus that it was in the mid-eighteenth century) and neither is it discontinuous (or clear-cut) nor is it, in all likelihood, identical across space. ${ }^{41}$ Moreover, the distribution of religiosity before secularization is unknown, although Section 4.2 suggests that region or département fixed effects would account for such differences across space since devotion may have been close to the maximum level everywhere. It is impossible to directly address these issues, and therefore the common-trend assumption cannot be tested for and a fuzzy DID à la de Chaisemartin

\footnotetext{
${ }^{37}$ In order to visualize the effect of secularization on the CDF of fertility, I generate a counterfactual distribution by setting religiosity to the maximum level everywhere in Appendix Figure A6.1.2.

${ }^{38}$ This is why I estimate Equation 4 with a linear probability model instead of logit or probit.

${ }^{39}$ This issue is known and has been acknowledged - for example, in Henry (1972a,b, 1978); Henry and Houdaille (1973); Séguy (2001) — and experienced firsthand by the author (Blanc and Wacziarg, 2020).

${ }^{40}$ Note that difference-in-differences is essentially a fixed-effects estimator.

${ }^{41}$ For example, the evidence presented about Provence in Section 4.2 suggests that secular values spread starting in the 1730 s.
} 
and D'Haultfœuille (2017) cannot be implemented formally. Nevertheless, the fact that secularization was a smooth process would likely result in the underestimation of the true effect since some places were likely already treated before 1760 and the design relies on the assumption that that was not the case. Moreover, by estimating the effect of religiosity in 1791 on fertility before secularization, it is possible to further draw inferences about whether religiosity in 1791 captures pre-existing differences or the extent of secularization.

Finally, it is possible to study the fertility decisions of second-generation migrants while holding constant unobserved institutional characteristics of places of arrival, following Algan and Cahuc (2010); Fernández (2011); Guiso, Sapienza and Zingales (2004). This methodology allows me to separate the effect of religious beliefs and norms passed through generations from that of confounding institutional characteristics. What is particularly novel in this setting is both the historical dimension and the fact that it accounts for institutional and cultural variation within the country. Indeed, the traditional approach only uses migrants surveyed recently, leverages between-country variation in place of origin, and assumes that there is no institutional variation within country in either place of origin or place of arrival. Here I leverage variation in religiosity at the district-of-origin level, holding constant district-of-birth characteristics. ${ }^{42}$

Table 5 displays the results. ${ }^{43}$ The first specification displays the baseline results with the full set of controls at the individual, town, and district-of-birth levels. In specifications 2 and 3, I add, respectively, fixed effects for département of birth and département of birth by decade. Point estimates increase, as suggested by the analysis in the rest of the paper, and the marginal effect of religiosity in 1791 on fertility is estimated to be between 1.4 and 1.5 children. All results are significant at the 1 percent level. In specification 4 , I extend the sample to all individuals observed between 1680 and 1920. Interacting religiosity in 1791 with a dummy that equals one if the individual was observed after 1760 - that is, after the start of secularization - allows me to identify the causal effect of religiosity. The point estimate is similar to that in the previous specifications and is significant at the 5 percent level. Moreover, I find that religiosity in 1791 only has a small and statistically insignificant effect on log fertility before 1760 , consistent with the fact that religiosity in 1791 does not capture pre-existing differences. ${ }^{44}$ Finally, specification 5 restricts the sample to second-generation migrants and includes district-of-birth fixed effects in order to account for unobserved institutional factors that might confound the analysis. I find that religiosity in 1791, in the district of parents, has a persistent and significant effect on fertility. These regressions show that higher fertility was the result of devotion in the eighteenth and in the nineteenth century, suggesting that dechristianization caused the early decline in fertility

\footnotetext{
${ }^{42}$ In order to account for correlation among parents (less than a third of second-generation migrants had parents born in different districts from each other), I also implement multiway clustered standard errors at the parents and districts of birth of parents levels.

${ }^{43}$ In Appendix Figure A6.2.1, I display the variation in religiosity in 1791 at the district-of-birth and district-ofbirth-of-parents levels, with and without fixed effects.

${ }^{44}$ Appendix Figure A6.2.2, Panel A displays the difference-in-differences result graphically. 
Table 5: Determinants of fertility at the individual level: causal identification

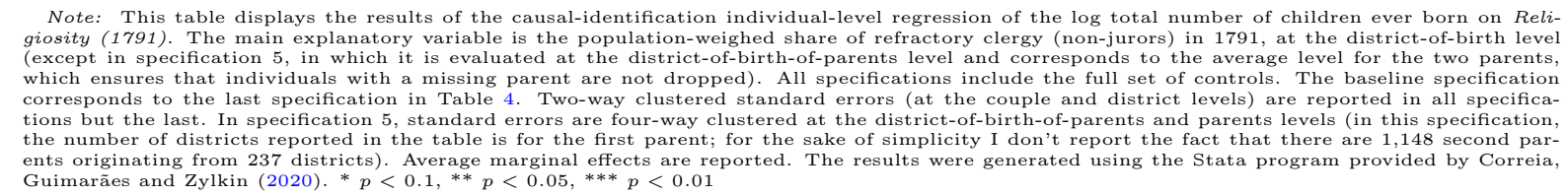

\begin{tabular}{|c|c|c|c|c|c|}
\hline & \multicolumn{5}{|c|}{ dep var: log fertility } \\
\hline & $\begin{array}{l}\text { (1) Baseline } \\
\text { specification }\end{array}$ & $\begin{array}{l}\text { (2) Fixed } \\
\text { Effects }\end{array}$ & $\begin{array}{l}\text { (3) Time- } \\
\text { varying FE }\end{array}$ & $\begin{array}{l}\text { (4) Diff- } \\
\text { in-diff }\end{array}$ & $\begin{array}{l}(5)^{a, b} \text { Second } \\
\text { gen migrants }\end{array}$ \\
\hline $\begin{array}{l}\text { Religiosity }(1791)^{a} \\
\times \text { After } 1760\end{array}$ & $\begin{array}{c}0.274^{* * *} \\
(0.088)\end{array}$ & $\begin{array}{c}0.395^{* * *} \\
(0.129)\end{array}$ & $\begin{array}{c}0.431^{* * *} \\
(0.134)\end{array}$ & $\begin{array}{c}0.091 \\
(0.171) \\
0.353^{* *} \\
(0.165)\end{array}$ & $\begin{array}{c}0.224^{* *} \\
(0.099)\end{array}$ \\
\hline
\end{tabular}

Marginal effect of religiosity on fertility

Between 1680 and 1759

Between 1760 and 1919

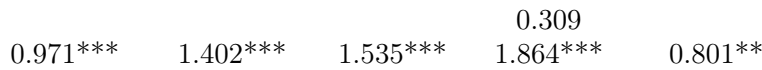

\begin{tabular}{|c|c|c|c|c|c|}
\hline \multicolumn{6}{|l|}{ Sample } \\
\hline Observed between 1680 and 1919 & & & \multicolumn{3}{|c|}{ Yes } \\
\hline Observed between 1760 and 1919 & Yes & Yes & Yes & & Yes \\
\hline \multicolumn{6}{|l|}{ Controls } \\
\hline Individual-level & Yes & Yes & Yes & Yes & Yes \\
\hline Religiosity (pre-secularization) & Yes & Yes & Yes & Yes & Yes \\
\hline Cultural factors and development & Yes & Yes & Yes & Yes & Yes \\
\hline Département of birth fixed effects & & Yes & Yes & Yes & \\
\hline Département of birth by decade fixed effects & & & Yes & Yes & \\
\hline District of birth fixed effects & & & & & Yes \\
\hline Observations & 11,649 & 11,649 & 11,450 & 16,413 & 1,433 \\
\hline Clusters $\left(\right.$ couples $\left.^{b}\right)$ & 10,155 & 10,155 & 9,973 & 14,200 & 1,146 \\
\hline Clusters $\left(\right.$ districts $\left.^{b}\right)$ & 438 & 438 & 427 & 449 & 234 \\
\hline Pseudo $R^{2}$ & 0.06 & 0.08 & 0.11 & 0.13 & 0.14 \\
\hline
\end{tabular}

${ }^{a}$ district of birth of parents in $(5),{ }^{b}$ more details in table notes regarding (5)

in eighteenth-century France.

Finally, it is possible to evaluate the effect of religiosity in 1791 over time, from 1680 to 1920. In what follows, I estimate the effect with forty-year periods (a higher frequency would require many more observations than are available). ${ }^{45}$ I display the results in Panel B of Appendix Figure A6.2.2. In the first period, 1680-1720, when secularization had likely not started anywhere, the estimated effect is virtually null, slightly negative, and not statistically significant. Then, in the period that immediately precedes the aggregate decline in fertility, the effect increases slightly and becomes positive, which is consistent with a smooth and heterogeneous-across-space process of secularization and with some places experiencing dechristianization earlier. Indeed, the process of secularization may have started before 1760 in some places, as in Provence, where there is evidence of important changes in the 1730s (Vovelle, 1973). Nevertheless, the effect is statistically insignificant

\footnotetext{
${ }^{45} \mathrm{Also}$, even with the forty-year periods, statistical power is insufficient to run a difference-in-differences regression by period, which adds to the limitations discussed above.
} 
before 1760. After 1760, which marks the start of aggregate-level dechristianization and the decline in fertility, religiosity in 1791 has a positive and statistically significant effect. The effect slightly increases at the time of the second wave of decline in fertility (during industrialization) and then decreases, consistent with a process of diffusion (Spolaore and Wacziarg, 2019) or of interaction between cultural and economic forces as documented by Squicciarini (2020).

\section{CONCLUDing REMARKS}

The remarkably early timing of the decline in fertility in France, more than a hundred years before the rest of Europe and in a period of stagnation, has long been a mystery. This research establishes that devotion was positively associated with fertility as early as in the eighteenth century, suggesting that secularization brought about the demographic transition in France.

Using a variety of novel sources and methods, I show that the Roman Catholic Church had a large effect on fertility in eighteenth- and nineteenth-century France. I leveraged new data on religiosity across time and space to measure dechristianization and to suggest that religiosity in 1791 does not capture pre-existing differences. Finally, with crowdsourced genealogies, I was able to study the determinants of fertility in France in the eighteenth century at the time of and before the decline, at the individual level. Taken together, my results suggest that dechristianization accounts for most of the early demographic transition. By tracing the cultural origins of the demographic transition, this paper seeks to address the role of ideas, preferences, and culture in shaping development. The results suggest that cultural change and preferences matter in the process of development. ${ }^{46}$ In particular, I establish that the transition from tradition to modernity played a role in the transition from stagnation to growth. ${ }^{47}$

For future research, it would be fascinating to explore the deep roots of the process of dechristianization in France and its short- and long-run effects on political outcomes and democratization, particularly during and following the French Revolution (Bois, 1960; Siegfried, 1913).

\section{REFERENCES}

Acemoglu, Daron, David H. Autor, and David Lyle. 2004. "Women, War, and Wages: The Effect of Female Labor Supply on the Wage Structure at Midcentury." Journal of Political Economy, 112(3): 497-551.

Algan, Yann, and Pierre Cahuc. 2010. "Inherited Trust and Growth." American Economic Review, 100(5): 2060-2092.

\footnotetext{
${ }^{46}$ In a sense, this echoes the work of Becker, Murphy and Tamura (1990) on the role of multiple equilibria and Galor and Moav (2002) on the role of preferences and human evolution.

${ }^{47}$ In this context, the consequences of low fertility are straightforward. However, as Jones (2020) points out, there can be unintended and harmful consequences if fertility is below replacement level in the long run.
} 
Altonji, Joseph G., Todd E. Elder, and Christopher R. Taber. 2005. "Selection on Observed and Unobserved Variables: Assessing the Effectiveness of Catholic Schools." Journal of Political Economy, 113(1): 151-184.

Ariès, Philippe. 1974. Western Attitudes toward Death From the Middle Ages to the Present ; translated by Patricia M. Ranum. Baltimore:Johns Hopkins University Press.

Ashraf, Quamrul, and Oded Galor. 2011. "Dynamics and Stagnation in the Malthusian Epoch." American Economic Review, 101(5): 2003-2041.

Ashraf, Quamrul, and Oded Galor. 2013. "The 'Out of Africa' Hypothesis, Human Genetic Diversity, and Comparative Economic Development." American Economic Review, 103(1): 1-46.

Bairoch, Paul, Jean Batou, and Pierre Chèvre. 1988. The Population of European Cities, 800-1850: Data Bank and Short Summary of Results. Geneve:Librairie Droz.

Barro, Robert J., and Rachel M. McCleary. 2003. "Religion and Economic Growth across Countries." American Sociological Review, 68(5): 760-781.

BDCassini. 2017. Geohistoricaldata. Paris:LaDéHiS, CRH, EHESS.

Beach, Brian, and W. Walker Hanlon. 2019. "Censorship, Family Planning, and the Historical Fertility Transition." National Bureau of Economic Research Working Paper 25752.

Becker, Gary S., Kevin M. Murphy, and Robert Tamura. 1990. "Human Capital, Fertility, and Economic Growth." Journal of Political Economy, 98(5, Part 2): S12-S37.

Belloni, Alexandre, Victor Chernozhukov, and Christian Hansen. 2013. "Inference on Treatment Effects after Selection among High-Dimensional Controls." The Review of Economic Studies, 81(2): 608-650.

Bénabou, Roland, Davide Ticchi, and Andrea Vindigni. 2015. "Forbidden Fruits: The Political Economy of Science, Religion, and Growth." National Bureau of Economic Research Working Paper 21105.

Blanc, Guillaume. 2020. "Demographic Change and Development from Crowdsourced Genealogies in Early Modern Europe." Working paper.

Blanc, Guillaume, and Masahiro Kubo. 2020. "School Building, Language, and Nation Building: Evidence From a Natural Experiment in France." Work in progress.

Blanc, Guillaume, and Romain Wacziarg. 2020. "Change and Persistence in the Age of Modernization: Saint-Germain-d'Anxure, 1730-1895." Explorations in Economic History, 78.

Bois, Paul. 1960. Paysans de l'Ouest. Le Mans:Vilaire.

Bolt, Jutta, and Jan Luiten van Zanden. 2014. "The Maddison Project: collaborative research on historical national accounts." The Economic History Review, 67(3): 627-651.

Boulard, Fernand. 1947. "Carte religieuse de la France rurale." Cahiers du clergé rural, 92: 403-414.

Boulard, Fernand. 1966. Premiers itinéraires en sociologie religieuse (2nd ed.). Paris:Éditions Ouvrières.

Braudel, Fernand. 1986a. The identity of France: History and environment; translated from the French by Sian Reynolds. Vol. 1. 1990 ed., London:Collins.

Braudel, Fernand. 1986b. The identity of France: People and production; translated from the French by Sian Reynolds. Vol. 2. 1990 ed., London:Collins. 
Brodeur, Abel, Mathias Lé, Marc Sangnier, and Yanos Zylberberg. 2016. "Star Wars: The Empirics Strike Back." American Economic Journal: Applied Economics, 8(1): $1-32$.

Brodeur, Abel, Nikolai Cook, and Anthony Heyes. 2020a. "Methods Matter: PHacking and Publication Bias in Causal Analysis in Economics." American Economic Review.

Brodeur, Abel, Nikolai Cook, and Anthony Heyes. 2020b. "A Proposed Specification Check for p-Hacking." AEA Papers and Proceedings, 110: 66-69.

Brown, John C., and Timothy W. Guinnane. 2002. "Fertility Transition in a Rural, Catholic Population: Bavaria, 1880-1910." Population Studies, 56(1): 35-49.

Brown, John C., and Timothy W. Guinnane. 2007. "Regions and time in the European fertility transition: problems in the Princeton Project's statistical methodology." The Economic History Review, 60(3): 574-595.

Buringh, Eltjo, and Jan Luiten van Zanden. 2009. "Charting the "Rise of the West": Manuscripts and Printed Books in Europe, a Long-Term Perspective from the Sixth through Eighteenth Centuries." The Journal of Economic History, 69(2): 409-445.

Burleigh, Michael. 2005. Earthly Powers: The Clash of Religion and Politics in Europe, from the French Revolution to the Great War. New York City:HarperCollins.

Case, Anne C. 1991. "Spatial Patterns in Household Demand." Econometrica, 59(4): 953965.

Chartier, Roger. 1991. The Cultural Origins of the French Revolution. Duke University Press.

Chaunu, Pierre. 1978. La mort à Paris, XVIe, XVIIe et XVIIIe siècles. Paris:Fayard.

Chernozhukov, Victor, Iván Fernández-Val, and Blaise Melly. 2013. "Inference on Counterfactual Distributions." Econometrica, 81(6): 2205-2268.

Clair, C. 1976. A History of European Printing. London:Academic.

Coale, Ansley J., and Susan C. Watkins. 1986. The Decline of Fertility in Europe. Princeton:Princeton University Press.

Colella, Fabrizio, Rafael Lalive, Seyhun Orcan Sakalli, and Mathias Thoenig. 2019. "Inference with Arbitrary Clustering." IZA DP 12584.

Conley, Timothy G. 1999. "GMM estimation with cross sectional dependence." Journal of Econometrics, 92(1): 1-45.

Correia, Sergio. 2014. "REGHDFE: Stata module to perform linear or instrumentalvariable regression absorbing any number of high-dimensional fixed effects." Statistical Software Components, Boston College Department of Economics.

Correia, Sergio, Paulo Guimarães, and Tom Zylkin. 2020. "Fast Poisson estimation with high-dimensional fixed effects." The Stata Journal, 20(1): 95-115.

Crouzet, François. 2003. "The Historiography of French Economic Growth in the Nineteenth Century." The Economic History Review, 56(2): 215-242.

Cummins, Neil. 2012. "Marital Fertility and Wealth During the Fertility Transition: Rural France, 1750-1850." The Economic History Review, 66(2): 449-476.

Darby, H.C., and H. Fullard. 1970. The New Cambridge Modern History, vol. 14. The New Cambridge Modern History, Cambridge:Cambridge University Press. 
Darnton, Robert. 1973. "The Encyclopédie Wars of Prerevolutionary France." The American Historical Review, 78(5): 1331-1352.

Darnton, Robert. 1978. "The History of Mentalités: Recent Writings on Revolution, Criminality, and Death in France." In Structure, Consciousness, and History. , ed. Richard Harvey Brown and Stanford M. Lyman, 112. Cambridge:Cambridge University Press.

Darnton, Robert. 1991. Edition et sédition. L'univers de la littérature clandestine au XVIIIe siècle. Paris:Gallimard.

Daudin, Guillaume, Raphaël Franck, and Hillel Rapoport. 2018. "Can Internal Migration Foster the Convergence in Regional Fertility Rates? Evidence from Nineteenth Century France." The Economic Journal.

de Chaisemartin, Clément, and Xavier D'Haultfouille. 2017. "Fuzzy Differencesin-Differences." The Review of Economic Studies, 85(2): 999-1028.

de la Croix, David, and Faustine Perrin. 2018. "How far can economic incentives explain the French fertility and education transition?" European Economic Review, 108: $221-245$.

Delventhal, Matthew J., Jesús Fernández-Villaverde, and Nezih Guner. 2019. "Demographic Transitions Across Time and Space." Working paper.

de Tocqueville, Alexis. 1856. The Ancien Régime and the French Revolution (2011, edited by Jon Elster, translated by Arthur Goldhammer). Cambridge:Cambridge University Press.

Febvre, Lucien, and Henri-Jean Martin. 1958. L'apparition du livre. Paris:Albin Michel.

Fernández, Raquel. 2011. "Does Culture Matter?" In Handbook of Social Economics. Vol. 1 of Handbook of Social Economics, ed. Jess Benhabib, Alberto Bisin and Matthew O. Jackson, Chapter 11, 481-510. North-Holland.

Forrest, Alan. 1989. Conscripts and Deserters: The Army and French Society During the Revolution and Empire. Oxford:Oxford University Press.

Franck, Raphaël, and Noel Johnson. 2016. "Can public policies lower religiosity? Evidence from school choice in France, 1878-1902." The Economic History Review, 69(3): 915-944.

Franck, Raphaël, and Stelios Michalopoulos. 2017. "Emigration during the French Revolution: Consequences in the Short and Longue Durée." National Bureau of Economic Research Working Paper 23936.

Gadille, Jacques. 1967. La pensée et l'action politiques des évêques français au début de la IIIe République, 1870-1883. Paris:Hachette.

Galor, Oded. 2011. Unified Growth Theory. Princeton:Princeton University Press.

Galor, Oded, and David Weil. 2000. "Population, Technology, and Growth: From the Malthusian Regime to the Demographic Transition and Beyond." American Economic Review, 90(4): 806-828.

Galor, Oded, and Omer Moav. 2002. "Natural Selection and the Origin of Economic Growth." The Quarterly Journal of Economics, 117(4): 1133-1191.

Gilliéron, Jules, and Edmond Edmont. 1902-1910. Atlas linguistique de la France. Vol. 1-9, Paris:Champion.

González-Bailón, Sandra, and Tommy E. Murphy. 2013. "The effects of social interactions on fertility decline in nineteenth-century France: An agent-based simulation experiment." Population Studies, 67(2): 135-155. 
Goodman-Bacon, Andrew. 2016. "The Long-Run Effects of Childhood Insurance Coverage: Medicaid Implementation, Adult Health, and Labor Market Outcomes." National Bureau of Economic Research Working Paper 22899.

Goudar, Ange. 1756. Les interêts de la France mal entendus, dans les branches de l'agriculture, de la population, des finances, du commerce, de la marine, et de l'industrie. Par un citoyen. Vol. 1, Coeur.

Granger, Clive W.J., and Harald F. Uhlig. 1990. "Reasonable extreme-bounds analysis." Journal of Econometrics, 44(1): 159-170.

Grendler, Paul F. 2017. The Jesuits and Italian Universities, 1548-1773. Washington:Catholic University of America Press.

Gu, Ariel, and Hong Il Yoo. 2019. "VCEMWAY: Stata module to adjust a Stata command's standard errors for multi-way clustering." Statistical Software Components, Boston College Department of Economics.

Guinnane, Timothy W. 2011. "The Historical Fertility Transition: A Guide for Economists." Journal of Economic Literature, 49(3): 589-614.

Guiso, Luigi, Paola Sapienza, and Luigi Zingales. 2004. "The Role of Social Capital in Financial Development." American Economic Review, 94(3): 526-556.

Hacker, J.David. 1999. "Child naming, religion, and the decline of marital fertility in nineteenth-century america." The History of the Family, 4(3): 339-365.

Hansen, Gary D., and Edward C. Prescott. 2002. "Malthus to Solow." American Economic Review, 92(4): 1205-1217.

Heldring, Leander, James A. Robinson, and Sebastian Vollmer. 2017. "The LongRun Impact of the Dissolution of the English Monasteries." Working paper.

Henry, Louis. 1972a. "Fécondité des Mariages dans le Quart Sud-Ouest de la France de 1720 à 1829 (I)." Annales, 27(3): 612-640.

Henry, Louis. 1972b. "Fécondité des Mariages dans le Quart Sud-Ouest de la France de 1720 à 1829 (suite)." Annales, 27(4): 977-1023.

Henry, Louis. 1978. "Fécondité des Mariages dans le Quart Sud-Est de la France de 1670 à 1829." Population, 33(4): 855-883.

Henry, Louis, and Jacques Houdaille. 1973. "Fécondité des Mariages dans le Quart Nord-Ouest de la France de 1670 à 1829." Population, 28(4): 873-924.

HMD. 2019. Human Mortality Database. University of California, Berkeley (USA), and Max Planck Institute for Demographic Research (Germany). Available at www.mortality.org or www.humanmortality.de (data downloaded on November 30, 2019).

Hoffman, Philip T. 1984. Church and Community in the Diocese of Lyon 1500-1789. New Haven and London:Yale University Press.

Hornung, Erik. 2014. "Immigration and the Diffusion of Technology: The Huguenot Diaspora in Prussia." American Economic Review, 104(1): 84-122.

Hsiang, Solomon M. 2010. "Temperatures and cyclones strongly associated with economic production in the Caribbean and Central America." Proceedings of the National Academy of Sciences, 107(35): 15367-15372.

Iannaccone, Laurence R. 1998. "Introduction to the Economics of Religion." Journal of Economic Literature, 36(3): 1465-1495.

Page 40 of 43 
ISTC. 2008. Incunabula Short-Title Catalogue. London:British Library.

Jedin, H., K. S. Latourette, and J. Martin. 1970. Atlas Zur Kirchengeschichte. Freiburg:Herder.

Jones, Charles I. 2020. "The End of Economic Growth? Unintended Consequences of a Declining Population." National Bureau of Economic Research Working Paper 26651.

Kaplanis, Joanna, Assaf Gordon, Tal Shor, Omer Weissbrod, Dan Geiger, Mary Wahl, Michael Gershovits, Barak Markus, Mona Sheikh, Melissa Gymrek, Gaurav Bhatia, Daniel G. MacArthur, Alkes L. Price, and Yaniv Erlich. 2018. "Quantitative Analysis of Population-Scale Family Trees With Millions of Relatives." Science, 360(6385): 171-175.

Kelly, Morgan. 2019. "The Standard Errors of Persistence." Working paper.

Knodel, John, and Etienne Van de Walle. 1979. "Lessons from the Past: Policy Implications of Historical Fertility Studies." Population and Development Review, 5(2): 217245.

Komlos, John. 2006. "Height of French Soldiers, 1716-1784." ICPSR, 4363.

Kremer, Michael. 1993. "Population Growth and Technological Change: One Million B.C. to 1990." The Quarterly Journal of Economics, 108(3): 681-716.

Leamer, Edward E. 1983. "Let's Take the Con Out of Econometrics." The American Economic Review, 73(1): 31-43.

Leamer, Edward E, and Herman B Leonard. 1983. "Reporting the Fragility of Regression Estimates." The Review of Economics and Statistics, 65(2): 306-317.

Le Bras, Gabriel. 1942-5. Introduction à l'histoire de la pratique religieuse en France. Bibliothèque de l'École des hautes-études Sciences religieuses, Paris:Presses universitaires de France.

Lechler, Marie, and Uwe Sunde. 2020. "Aging, Proximity to Death, and Religiosity." Population and Development Review.

Lesthaeghe, Ron. 1983. "A Century of Demographic and Cultural Change in Western Europe: An Exploration of Underlying Dimensions." Population and Development Review, 9(3): 411-435.

Lesthaeghe, Ron. 2010. "Long term spatial continuities in demographic innovation. Insights from the Belgian example, 1846-2000." Population Studies Center Research Report $10-695$.

Lévy-Leboyer, Maurice. 1968. "La croissance économique en France au XIXe siècle. Résultats préliminaires." Annales, 23(4): 788-807.

Lévy-Leboyer, Maurice, and François Bourguignon. 1985. L'économie Française au XIXe siècle. Analyse Macro-économique. Paris:Economica.

Maire, Catherine. 1998. De la cause de Dieu à la cause de la Nation. Le jansénisme au XVIIIe siècle. Gallimard.

Maire, Catherine. 2019. L'Église dans l'État. Politique et religion dans la France des Lumières. Paris:Gallimard.

Marion, Henri. 1912. La dîme ecclésiastique en France au XVIIIe siècle et sa suppression. Étude d'histoire du droit suivie d'un aperçu sur les dîmes inféodées à la même époque. Bordeaux:Imprimerie de l'Université.

McCloskey, Deirdre N. 2016. Bourgeois Equality: How Ideas, Not Capital or Institutions, Enriched the World. Chicago:University of Chicago Press. 
Moheau, Jean-Baptiste. 1778. Recherches et considerations sur la population de la France. Paris:Moutard.

Mokyr, Joel. 2016. A Culture of Growth: The Origins of the Modern Economy. Princeton:Princeton University Press.

Mours, Samuel. 1958. Les Églises Réformées en France. Tableaux et Cartes. Paris:Librairie Protestante.

Murphy, Tommy E. 2015. "Old Habits Die Hard (Sometimes)." Journal of Economic Growth, 20(2): 177-222.

Noonan, John T. 1965. Contraception (1986 ed). Cambridge:Harvard University Press.

Norberg, Kathryn. 1985. Rich and Poor in Grenoble, 1600-1814. University of California Press.

Oster, Emily. 2016. "Unobservable Selection and Coefficient Stability: Theory and Evidence." Journal of Business \& Economic Statistics, 1-18.

Perez, Céline. 1999. "Les Refus de sacrement d'après les Nouvelles ecclésiastiques, 17561789." Mémoire de maîtrise (dir. Bernard Hours), Lyon 3.

Sauvy, Alfred. 1962. La prévention des naissances. Paris:Presses Universitaires de France.

Schulz, Jonathan F., Duman Bahrami-Rad, Jonathan P. Beauchamp, and Joseph Henrich. 2019. "The Church, intensive kinship, and global psychological variation." Science, 366(6466).

Séguy, Isabelle. 2001. La population de la France de 1670 à 1829: l'enquête Louis Henry et ses données. Classiques de l'économie et de la population, PAris:INED.

SGF. 1878. Annuaire Statistique de la France. Paris:Imprimerie Nationale.

SGF. 1901. L'enseignement primaire et secondaire de 1865 à 1906 (Statistiques Générales de la France). Atelier du Centre de recherches historiques, données traitées au CRH, mis en ligne le 05 février 2011, consulté le 16 juin 2020.

Siegfried, Andre. 1913. Tableau politique de la France de l'Ouest sous la Troisième République. Paris:Librairie Armand Colin.

Spolaore, Enrico, and Romain Wacziarg. 2009. "The Diffusion of Development." The Quarterly Journal of Economics, 124(2): 469-529.

Spolaore, Enrico, and Romain Wacziarg. 2013. "How Deep Are the Roots of Economic Development?" Journal of Economic Literature, 51(2): 325-69.

Spolaore, Enrico, and Romain Wacziarg. 2019. "Fertility and Modernity." Working paper.

Squicciarini, Mara P. 2020. "Devotion and Development: Religiosity, Education, and Economic Progress in 19th-century France." American Economic Review.

Squicciarini, Mara P., and Nico Voigtländer. 2015. "Human Capital and Industrialization: Evidence from the Age of Enlightenment." The Quarterly Journal of Economics, 130(4): 1825-1883.

Squicciarini, Mara P., and Nico Voigtländer. 2016. "Knowledge Elites and Modernization: Evidence from Revolutionary France." Working paper.

Sunde, Uwe, and Lukas Rosenberger. 2019. "Human Capital, Enlightenment, and the Growth Take-off in France." Work in progress.

Tackett, Timothy. 1986. Religion, Revolution, and Regional Culture in EighteenthCentury France: The Ecclesiastical Oath of 1791. Princeton:Princeton University Press. 
Tibshirani, Robert. 1996. "Regression Shrinkage and Selection via the Lasso." Journal of the Royal Statistical Society, 58(1): 267-288.

Tingle, Elizabeth C. 2012. Purgatory and Piety in Brittany, 1480-1720. Farnham:Ashgate Publishing, Ltd.

Todd, Emmanuel. 1990. L'invention de l'Europe. Paris:Seuil.

Todd, Emmanuel, and Hervé Le Bras. 1981. L'invention de la France. Atlas anthropologique et politique. Paris:Gallimard, coll NRF Essais.

Urminsky, Oleg, Christian Hansen, and Victor Chernozhukov. 2019. "The Doublelasso Method for Principled Variable Selection." PsyArXiv.

Vaillant, Gauthier, and Audrey Dufour. 2013. "Baptêmes, mariages, prêtres, l'Église de France en cartes (article, data, accessed June 16, 2020)." La Croix.

Van de Walle, Etienne. 2005. "Birth prevention before the era of modern contraception." Population and Societies, 418.

Van de Walle, Etienne, and Helmut Muhsam. 1995. "Fatal Secrets and the French Fertility Transition." Population and Development Review, 21(2): 261-279.

Van Kley, Dale K. 1996. The Religious Origins of the French Revolution: From Calvin to the Civil Constitution, 1560-1791. New Haven and London:Yale University Press.

Voigtländer, Nico, and Hans-Joachim Voth. 2012. "Persecution Perpetuated: The Medieval Origins of Anti-Semitic Violence in Nazi Germany." The Quarterly Journal of Economics, 127(3): 1339-1392.

Vovelle, Michel. 1973. Piété baroque et déchristianisation en Provence au XVIIIe siècle: Les attitudes devant la mort d'après les clauses des testaments. Paris:Pion.

Vovelle, Michel. 1982. Idéologies et Mentalités. Paris:Maspero.

Weber, Eugen. 1976. Peasants into Frenchmen: The Modernization of Rural France, 1870-1914. Stanford:Stanford University Press.

Weir, David R. 1994. "New Estimates of Nuptiality and Marital Fertility in France, 17401911." Population Studies, 48(2): 307-331.

Wrigley, Edward A. 1985a. "The Fall of Marital Fertility in Nineteenth-Century France: Exemplar or Exception? (Part I)." European Journal of Population / Revue européenne de Démographie, 1(1): 31-60.

Wrigley, Edward A. 1985b. "The Fall of Marital Fertility in Nineteenth-Century France: Exemplar or Exception? (Part II)." European Journal of Population / Revue européenne de Démographie, 1(2): 141-177. 
Online appendix to Modernization Before Industrialization (not for publication) 


\section{Appendix 2- Historical Background and literature}

\section{A2.1 Demographic transition and development}

Figure A2.1.1: Demographic transition and GDP per capita growth in France and England

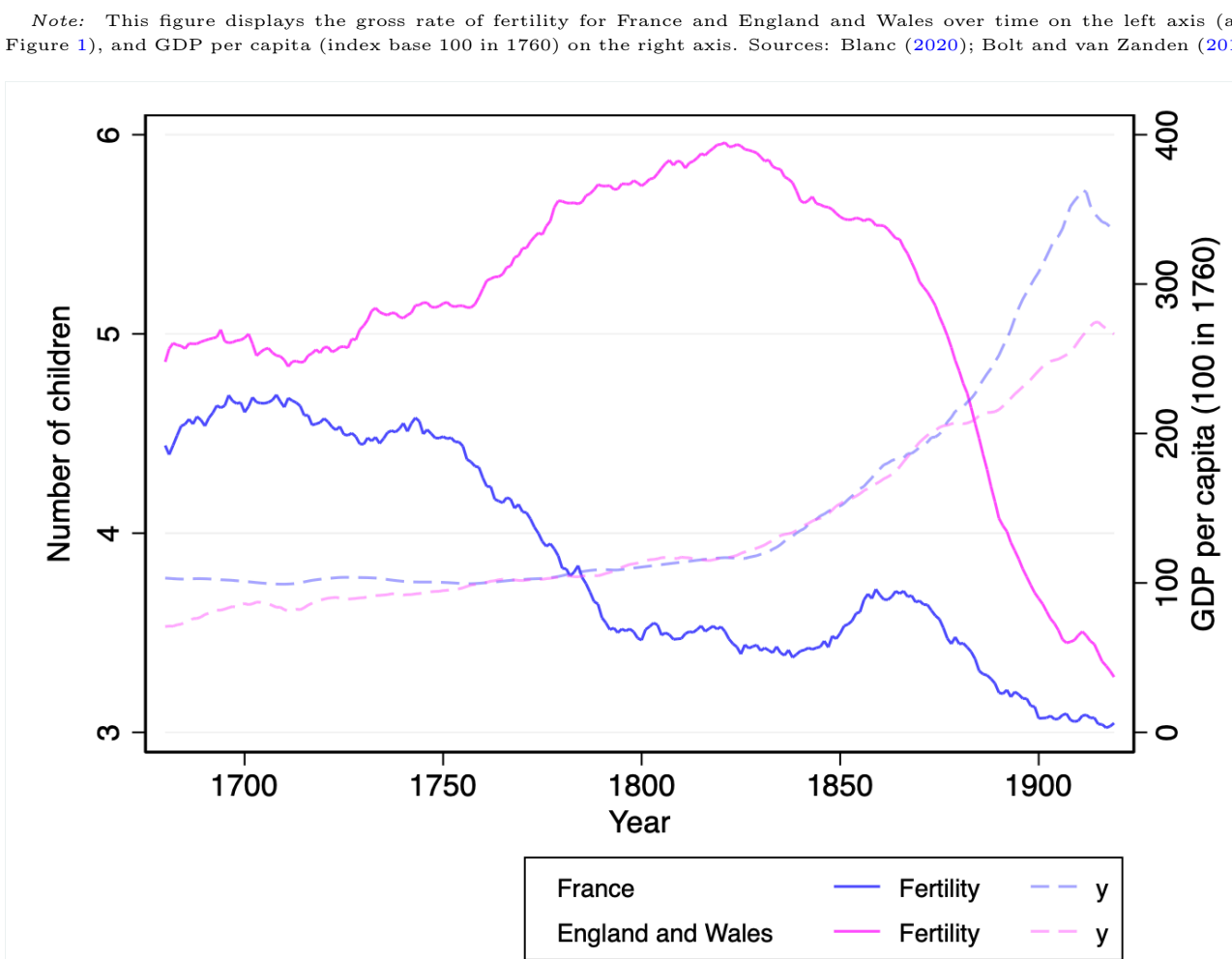

\section{A2.2 Further details on Jansenism in the eighteenth century}

Jansenism spread to France from Louvain after the posthumous publication in 1640 of Augustinus by Cornelius Jansen, a Catholic bishop influenced by Lutheran ideas ("a Catholic Lutheran" (Burleigh, 2005, p. 34)). Jansenists advocated a rigorist view of Catholicism, with an emphasis on predestination of the elect to salvation, the limitation of sacrements and the need for penitence: "Jansenism accentuated humankind's pristine perfection and original innocence, the better to underscore the catastrophe of the original sin of disobedient pride and the ensuing fall." (Van Kley, 1996, p. 60); "an austere, rigorous creed, that stressed individual study of the scripture in the vernacular, the need for sincere contrition rather than mere fear of eternal damnation, the infrequency of communion, and the remoteness of God from a concupiscent humanity." (Burleigh, 2005, p. 34).

They also strongly opposed the elitism of Jesuits: "this set Jansenism on a collision course with baroquely lax Catholicism in which the Jesuits could allegedly finesse everything this way or that." (Burleigh, 2005, p. 34). Van Kley (1996) writes that "against the Jesuits' preference for Latin and elites, Port-Royal's director Le Maitre de 
Sacy began to translate the Bible into French, and Pascal appealed to literate opinion", referring to the Council of Trent's interdiction against vernacular Bible translation and the support of famous scientists such as Blaise Pascal.

The first half of the eighteenth century in France was characterized by major religious turmoil and controversies between the two groups, eventually leading to the decline and demise of Jansenism. In 1709, Louis XIV decreed that the Abbey of Port Royal des Champs, the center of Jansenism in France, be demolished. In 1713, the Unigenitus papal bull, supported by the Jesuits, set a number of fierce religious fights into motion. The bull was an apostolic constitution condemning 101 Jansenist views described by theologian Pasquier Quesnel.

In the following years, the bull generated major controversies (Van Kley, 1996). The Convulsionnaires of SaintMédard, a group of Jansenists, would gather in cemeteries and holy places to convulse and declare miraculous healings. Until the mid-eighteenth century, Jesuits bishops and clergy would deny sacraments and burial in consecrated ground to the faithful unless they could provide a proof of acceptance of Unigenitus such as billets de confession, papers that affirmed submission to the bull and had to be signed by the archbishop of Paris. The billets were denounced by Catholics in news articles all across France (Perez, 1999). Yet, the bull came into law in 1730 (Maire, 1998).

\section{Appendix 3- Data}

\section{A3.2 Département level}

Table A3.2.1: Summary statistics at the département level

Note: All observations weighed by population in 1793

\begin{tabular}{|c|c|c|c|c|c|}
\hline & Mean & St. dev. & Minimum & Maximum & $\mathrm{N}$ \\
\hline \multicolumn{6}{|l|}{ Panel A: Fertility } \\
\hline Transition date (below .5) & 1864.25 & 35.00 & 1831.00 & 1931.00 & 89 \\
\hline Marital fertility index $I_{g}(1831)$ & 0.56 & 0.12 & 0.35 & 0.81 & 77 \\
\hline Marital fertility index $I_{g}(1836)$ & 0.54 & 0.11 & 0.33 & 0.78 & 77 \\
\hline Marital fertility index $I_{g}(1841)$ & 0.52 & 0.11 & 0.32 & 0.76 & 77 \\
\hline Marital fertility index $I_{g}(1846)$ & 0.51 & 0.11 & 0.31 & 0.73 & 77 \\
\hline Marital fertility index $I_{g}(1851)$ & 0.49 & 0.11 & 0.30 & 0.75 & 85 \\
\hline Marital fertility index $I_{g}(1856)$ & 0.49 & 0.11 & 0.29 & 0.74 & 85 \\
\hline Marital fertility index $I_{g}(1861)$ & 0.49 & 0.12 & 0.28 & 0.78 & 88 \\
\hline Marital fertility index $I_{g}(1866)$ & 0.49 & 0.13 & 0.28 & 0.77 & 88 \\
\hline Marital fertility index $I_{g}(1871)$ & 0.49 & 0.13 & 0.28 & 0.81 & 86 \\
\hline Marital fertility index $I_{g}(1876)$ & 0.48 & 0.14 & 0.27 & 0.84 & 86 \\
\hline Marital fertility index $I_{g}(1881)$ & 0.48 & 0.14 & 0.27 & 0.82 & 86 \\
\hline Marital fertility index $I_{g}(1886)$ & 0.45 & 0.13 & 0.25 & 0.80 & 86 \\
\hline Marital fertility index $I_{g}(1891)$ & 0.43 & 0.12 & 0.23 & 0.77 & 86 \\
\hline Marital fertility index $I_{g}(1896)$ & 0.41 & 0.12 & 0.23 & 0.74 & 86 \\
\hline Marital fertility index $I_{g}(1901)$ & 0.40 & 0.11 & 0.23 & 0.72 & 86 \\
\hline \multicolumn{6}{|l|}{ Panel B: Religiosity } \\
\hline Religiosity (1791) & 0.49 & 0.22 & 0.08 & 0.90 & 85 \\
\hline Clergymen per 10,000 inhabitants (1791) & 19.07 & 6.75 & 3.30 & 41.23 & 84 \\
\hline
\end{tabular}


Abbeys (1756)

Tithe (1750)

Huguenots per 10,000 inhabitants (1815)

Centuries of Jesuit presence (bef. 1763)

Panel C: Cultural and institutional factors

Books printed (1500)

Presence of a printing press (1500)

Presence of a university (bef. 1750)

$\log 1+$ Encyclopedie sub. per 10,000 inhabitants (1777-1779)

Pays d'Etat

Pays d'imposition

Share of deserters among conscripts (1798-1805)

Linguistic distance from French (1900)

Panel D: Education and schooling

Literacy (1829)

Literacy (1835)

Literacy (1840)

Literacy (1845)

Literacy (1850)

Literacy (1855)

Literacy (1860)

Literacy (1865)

Literacy (1870)

Literacy (1875)

Literacy (1881)

Literacy (1886)

Literacy (1891)

Literacy (1896)

Panel E: Pre-industrial development

Average soldier height (bef. 1760)

Population (1793)

Population (1831)

Population (1836)

Population (1841)

Population (1846)

Population (1856)

Population (1861)

Population (1866)

Population (1871)

Population (1876)

Population (1881)

Population (1886)

Population (1891)

Population (1896)
Population (1851)

Population (1901)

$\begin{array}{ccccc}2.52 & 2.37 & 0.00 & 13.00 & 89 \\ 15.61 & 6.39 & 9.00 & 40.00 & 87 \\ 167.15 & 443.76 & 0.16 & 3424.00 & 83 \\ 1.26 & 0.69 & 0.00 & 2.02 & 89\end{array}$

$\begin{array}{lllll}140.87 & 583.43 & 0.00 & 3264.00 & 85\end{array}$

$\begin{array}{lllll}0.43 & 0.50 & 0.00 & 1.00 & 85\end{array}$

$\begin{array}{lllll}0.31 & 0.46 & 0.00 & 1.00 & 85\end{array}$

$\begin{array}{lllll}0.96 & 0.76 & 0.00 & 3.52 & 86\end{array}$

$\begin{array}{lllll}0.33 & 0.47 & 0.00 & 1.00 & 89\end{array}$

$\begin{array}{lllll}0.08 & 0.27 & 0.00 & 1.00 & 89\end{array}$

$\begin{array}{lllll}26.76 & 12.56 & 4.50 & 54.50 & 84\end{array}$

$\begin{array}{lllll}0.56 & 0.19 & 0.21 & 0.88 & 87\end{array}$

$\begin{array}{lllll}45.75 & 17.47 & 14.30 & 82.50 & 85\end{array}$

$\begin{array}{lllll}53.15 & 19.48 & 18.20 & 91.30 & 85\end{array}$

$\begin{array}{lllll}56.51 & 20.28 & 18.40 & 97.10 & 85\end{array}$

$\begin{array}{lllll}59.89 & 19.32 & 22.70 & 97.70 & 85\end{array}$

$\begin{array}{lllll}63.89 & 18.51 & 25.70 & 97.00 & 85\end{array}$

$\begin{array}{lllll}66.24 & 17.95 & 26.10 & 96.30 & 85\end{array}$

$\begin{array}{lllll}69.10 & 17.02 & 32.10 & 96.10 & 88\end{array}$

$\begin{array}{lllll}73.36 & 15.59 & 37.90 & 97.00 & 88\end{array}$

$\begin{array}{lllll}78.82 & 13.53 & 46.80 & 98.30 & 88\end{array}$

$\begin{array}{lllll}82.21 & 11.04 & 50.90 & 98.30 & 85\end{array}$

$\begin{array}{lllll}86.52 & 8.87 & 58.60 & 98.50 & 84\end{array}$

$\begin{array}{lllll}89.89 & 7.01 & 64.90 & 98.80 & 85\end{array}$

$\begin{array}{lllll}92.84 & 5.56 & 73.50 & 99.10 & 85\end{array}$

$\begin{array}{lllll}94.93 & 4.21 & 80.60 & 99.70 & 85\end{array}$

$\begin{array}{ccccc}-0 & 1 & -1 & 2 & 89 \\ 353,555 & 139,347 & 36,000 & 748,030 & 89 \\ 410,173 & 181,509 & 49,929 & 965,559 & 87 \\ 433,808 & 190,525 & 51,423 & 1,068,565 & 86 \\ 443,038 & 198,335 & 52,364 & 1,114,788 & 87 \\ 452,682 & 217,157 & 55,199 & 1,254,810 & 89 \\ 459,964 & 223,171 & 56,491 & 1,268,039 & 86 \\ 465,172 & 246,278 & 53,220 & 1,447,785 & 88 \\ 494,149 & 322,159 & 55,551 & 2,004,490 & 88 \\ 500,334 & 357,101 & 56,127 & 2,207,445 & 89 \\ 499,197 & 371,956 & 56,030 & 2,286,577 & 89 \\ 515,598 & 399,923 & 67,818 & 2,471,999 & 89 \\ 532,002 & 460,649 & 73,347 & 2,865,982 & 89 \\ 542,974 & 490,648 & 78,844 & 3,040,775 & 89 \\ 548,924 & 522,411 & 82,649 & 3,224,743 & 89 \\ 556,109 & 558,329 & 86,921 & 3,432,669 & 89 \\ 568,526 & 613,202 & 91,128 & 3,777,679 & 89\end{array}$

Panel F: Contemporary development

Urbanization (1793)

Urbanization (1831)

Urbanization (1836)

$\begin{array}{lllll}0.18 & 0.16 & 0.02 & 0.86 & 86 \\ 0.19 & 0.16 & 0.02 & 0.87 & 85 \\ 0.19 & 0.16 & 0.02 & 0.89 & 86\end{array}$




\begin{tabular}{llllll} 
Urbanization (1841) & 0.19 & 0.16 & 0.02 & 0.88 & 87 \\
Urbanization (1846) & 0.20 & 0.16 & 0.03 & 0.89 & 87 \\
Urbanization (1851) & 0.21 & 0.17 & 0.02 & 0.89 & 85 \\
Urbanization (1856) & 0.22 & 0.17 & 0.03 & 0.91 & 87 \\
Urbanization (1861) & 0.23 & 0.17 & 0.04 & 0.93 & 88 \\
Urbanization (1866) & 0.23 & 0.17 & 0.04 & 0.94 & 88 \\
Urbanization (1871) & 0.24 & 0.18 & 0.04 & 0.95 & 89 \\
Urbanization (1876) & 0.25 & 0.18 & 0.05 & 0.95 & 89 \\
Urbanization (1881) & 0.26 & 0.18 & 0.05 & 0.96 & 89 \\
Urbanization (1886) & 0.27 & 0.18 & 0.05 & 0.96 & 89 \\
Urbanization (1891) & 0.28 & 0.18 & 0.05 & 0.97 & 89 \\
Urbanization (1896) & 0.29 & 0.18 & 0.05 & 0.97 & 89 \\
Urbanization (1901) & 0.30 & 0.18 & 0.05 & 0.97 & 89 \\
\hline \hline
\end{tabular}

Table A3.2.2: Control variables

Note: This table displays the control variables used throughout in Section 5.

\begin{tabular}{|c|c|c|}
\hline Specification & Variable & Source \\
\hline \multirow[t]{6}{*}{$(2)$} & Religiosity (pre-secularization) & \\
\hline & Clergymen per 10,000 inhabitant (1791) & Tackett (1986) \\
\hline & Tithe (1750) & Marion (1912) \\
\hline & Huguenots per 10,000 inhabitant (1815) & Mours (1958) \\
\hline & Centuries of Jesuit presence (bef. 1763) & Grendler (2017) \\
\hline & Abbeys (1756) & $\begin{array}{lll}\text { BDCassini } \quad(2017) ; & \text { Franck } & \text { and } \\
\text { Michalopoulos (2017) } & \end{array}$ \\
\hline (4) & Institutional (a) and cultural (b) factors & \\
\hline \multirow[t]{2}{*}{$-\mathrm{a}-$} & Dummies for Pays status (Election, Etat, Imposition) & Wikipedia \\
\hline & Share of deserters among conscripts (1798-1805) & Forrest (1989) \\
\hline \multirow[t]{5}{*}{$-b-$} & Presence of a printing press (1500) & Clair (1976); Febvre and Martin (1958) \\
\hline & Books printed $(1500)$ & ISTC (2008) \\
\hline & $\log 1+$ Encyclopedie sub. per 10,000 inhab. (1777-1779) & Darnton (1973) \\
\hline & Linguistic distance from French $(1900)^{49}$ & Gilliéron and Edmont (1902-1910) \\
\hline & Presence of a university (bef. 1750) & $\begin{array}{l}\text { Darby and Fullard (1970); Jedin, La- } \\
\text { tourette and Martin (1970) }\end{array}$ \\
\hline \multirow[t]{2}{*}{$(5)$} & Education and schooling & \\
\hline & Literacy rate (year of observation) & SGF (1878) \\
\hline \multirow[t]{3}{*}{ (6) } & Pre-industrial development & \\
\hline & tpopulation density (year of observation) & BDCassini (2017) \\
\hline & Soldier height $(1716-1759)$ & Komlos (2006) \\
\hline \multirow[t]{2}{*}{ (7) } & Contemporary development & \\
\hline & $\log 1+$ urbanization (year of observation) & BDCassini (2017) \\
\hline
\end{tabular}


Figure A3.2.1: Maps

Note: This figure displays the spatial distribution of some variables of interest.

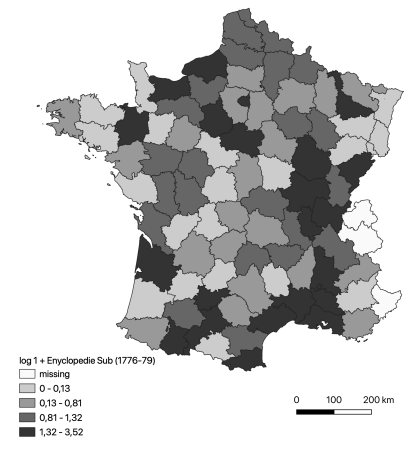

(Panel A) $\log 1+$ Encyclopedie sub. per 10,000 inhabitants $(1777-79)$

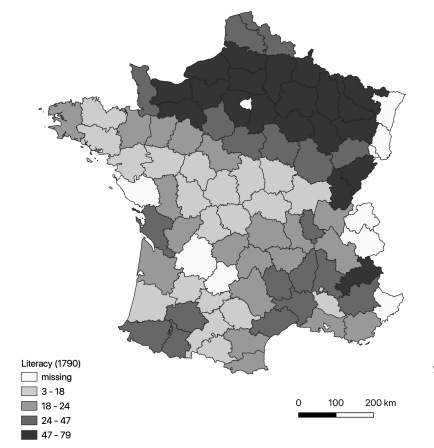

(Panel D) Literacy (1790)

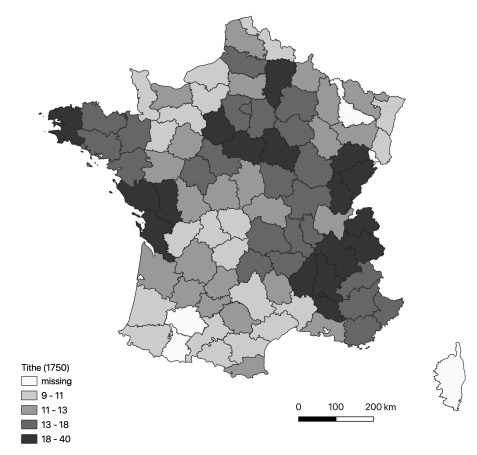

(Panel G) Tithe (1750)

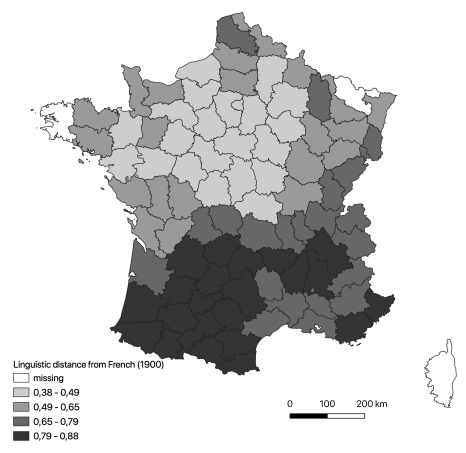

(Panel B) Linguistic distance from French (1900)

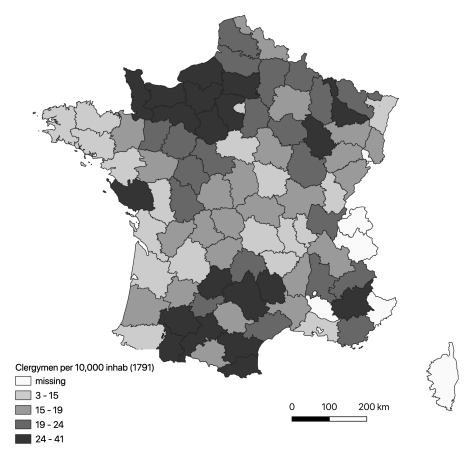

(Panel E) Clergymen per 10,000 inhabitants (1791)

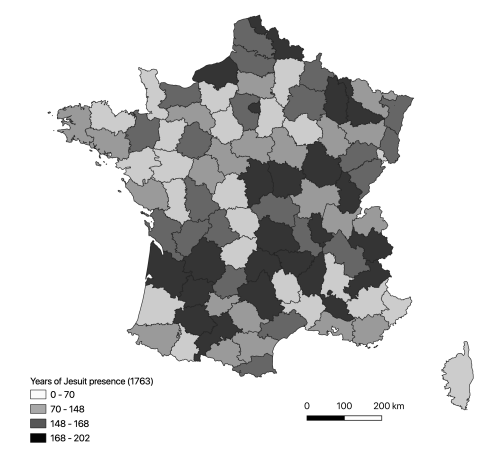

(Panel H) Years of jesuit presence (before 1763)

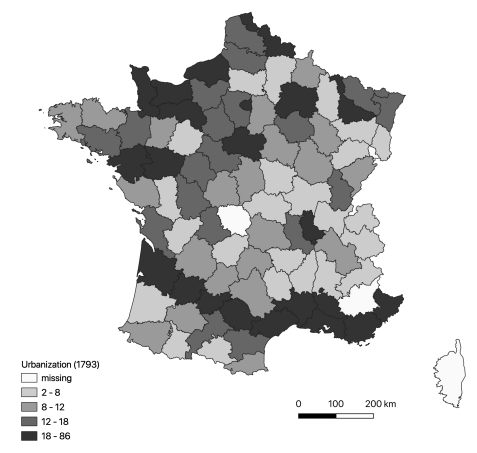

(Panel C) Urbanization (1793)

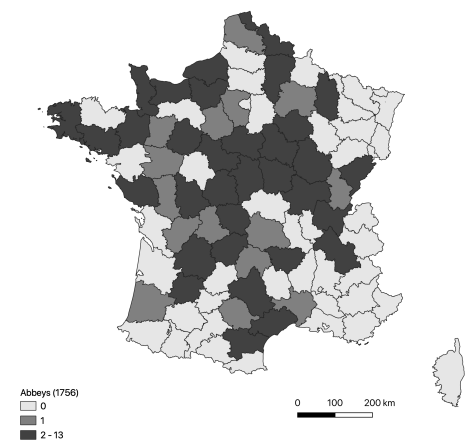

(Panel F) Abbeys (1756)

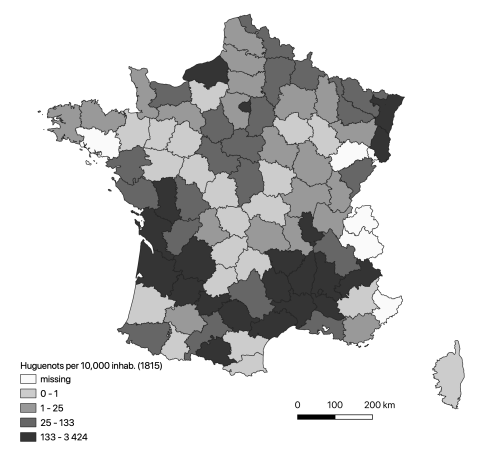

(Panel I) Huguenots per 10, 000 inhabitants (1815) 
A3.3 Individual level

Figure A3.3.1: Individual-level sample Note: This figure displays towns used in the fertility sample in the individual level dataset. The fertility sample consists of
all individuals with a recorded horizontal lineage.

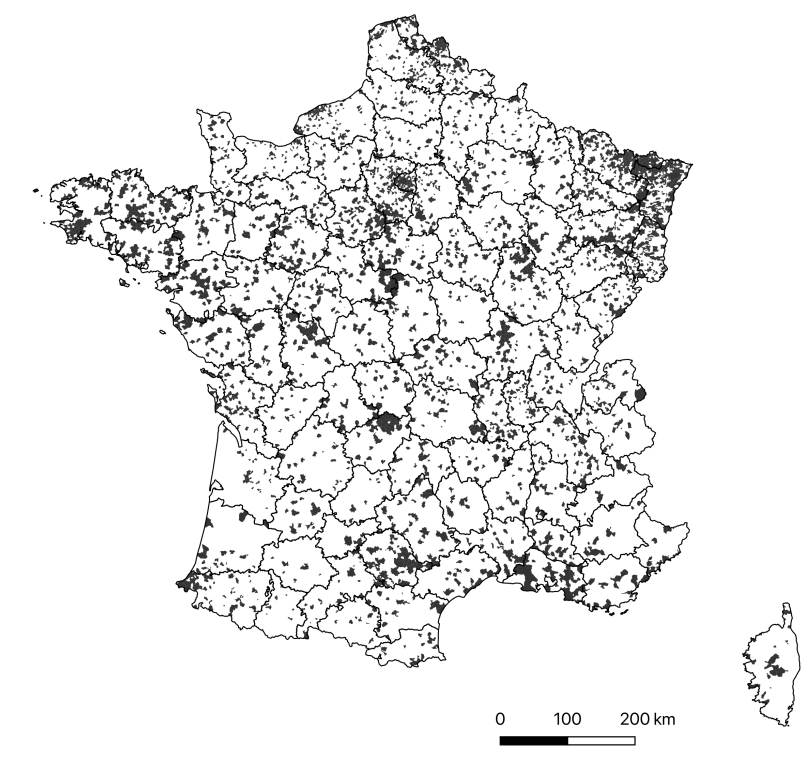

Fertility sample

Table A3.3.1: Summary statistics at the individual and district levels

\begin{tabular}{|c|c|c|c|c|c|}
\hline & Mean & St. dev. & Minimum & Maximum & $\mathrm{N}$ \\
\hline \multicolumn{6}{|l|}{ Panel A: Fertility } \\
\hline Number of children & 3.84 & 3.24 & 1.00 & 36.00 & 17,358 \\
\hline Age at birth of first child & 29.14 & 6.91 & 15.00 & 64.58 & 16,995 \\
\hline Male dummy & 0.61 & 0.49 & 0.00 & 1.00 & 17,358 \\
\hline \multicolumn{6}{|l|}{ Panel B: Religiosity (district level) } \\
\hline Religiosity (1791) & 0.59 & 0.29 & 0.00 & 1.00 & 17155 \\
\hline Abbeys (1756) & 0.44 & 0.79 & 0.00 & 7.00 & 17357 \\
\hline Centuries of Jesuit presence (bef. 1763) & 0.59 & 0.76 & 0.00 & 2.02 & 17357 \\
\hline \multicolumn{6}{|c|}{ Panel C: Development and Enlightenment (town and district level) } \\
\hline Urbanization (year of observation) & 0.21 & 0.41 & 0.00 & 1.00 & 17358 \\
\hline $\log 1+$ Encyclopedie per 10,000 inhabitants $(1777-1779)$ & 0.59 & 1.02 & 0.00 & 5.55 & 17258 \\
\hline
\end{tabular}


Figure A3.3.2: Selection in individual-level data

\begin{abstract}
Note: This figure displays fertility, urbanization, and life expectancy at 30 series over time in the fertility sample of the crowdsourced genealogies in France. In each figure, the corresponding series is displayed from the crowdsourced data as well as from representative data for Europe (Bairoch, Batou and Chèvre (1988) for urbanization, HMD (2019) for life expectancy at 30 , census data and Coale and Watkins (1986) for fertility).
\end{abstract}

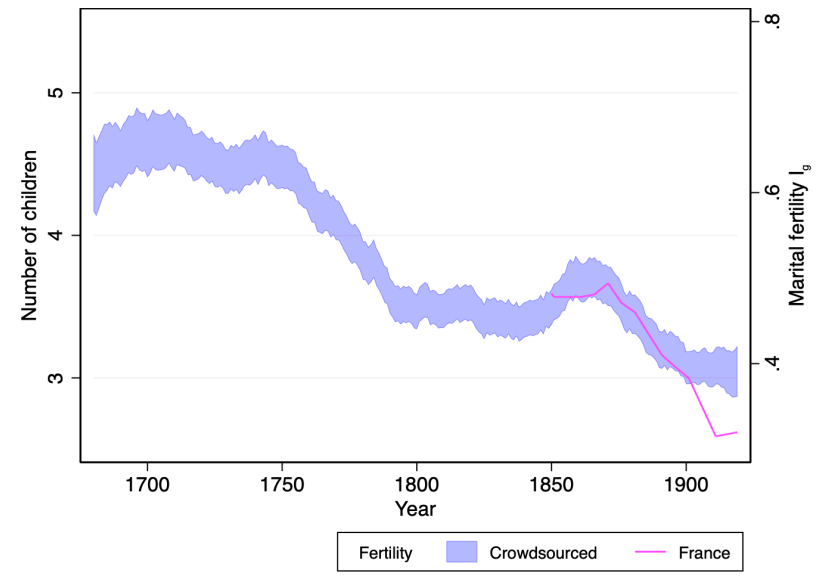

(Panel A) Fertility

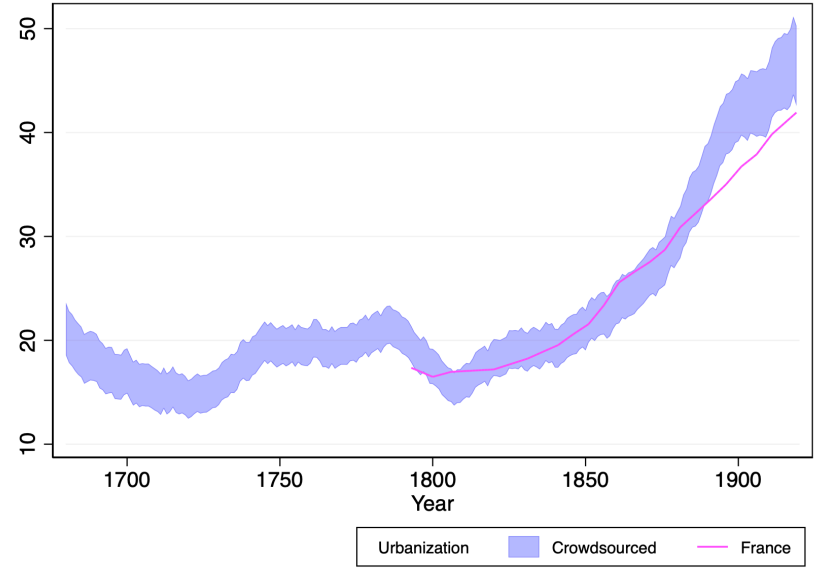

(Panel B) Urbanization

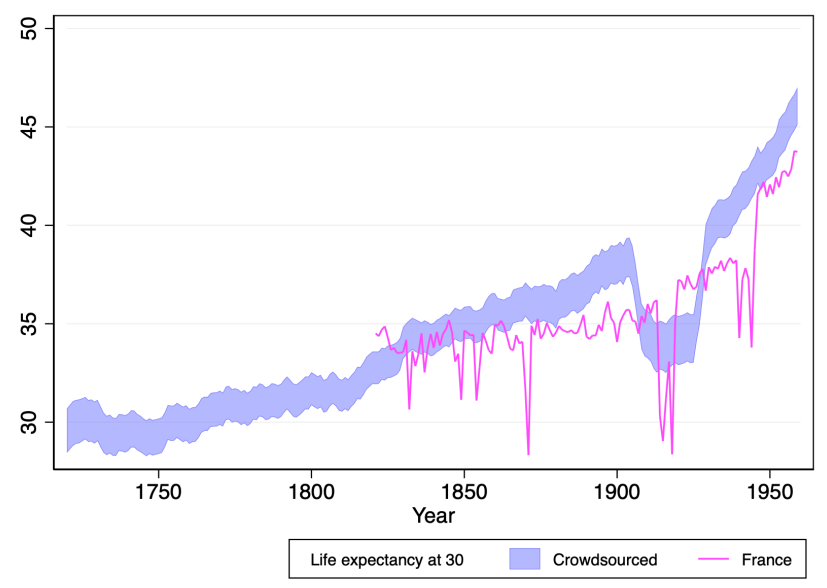

(Panel C) Mortality 


\section{Appendix 4- Religiosity and secularization}

\section{A4.1 Persistence of religious practice}

Table A4.1.1: Persistence of religious practice (before secularization)

\begin{tabular}{|c|c|c|c|c|c|c|c|c|}
\hline \multicolumn{9}{|l|}{$\begin{array}{l}\text { Note: This table displays the results of the cro } \\
\text { in } 1791 \text {. The proxies of religiosity before secular } \\
\text { deserters among conscripts in the French army } \\
\text { Robust standard errors are reported at the dépar } \\
\text { cations } 7 \text { and } 8 \text {. } \\
+p<0.2,{ }^{*} p<0.1, * * p<0.05, * * * p<0.01 \\
\end{array}$} \\
\hline & \multicolumn{6}{|c|}{ Département level } & \multicolumn{2}{|c|}{ District level } \\
\hline & (1) & (2) & (3) & (4) & (5) & (6) & (7) & (8) \\
\hline Clergymen per 10,000 inhab. (1791) & $\begin{array}{l}-0.003 \\
(0.003)\end{array}$ & & & & & $\begin{array}{l}-0.003 \\
(0.004)\end{array}$ & & \\
\hline Abbeys (1756) & & $\begin{array}{c}0.006 \\
(0.009)\end{array}$ & & & & $\begin{array}{c}0.008 \\
(0.009)\end{array}$ & $\begin{array}{l}-0.011 \\
(0.014)\end{array}$ & $\begin{array}{l}-0.034 \\
(0.021)\end{array}$ \\
\hline Tithe (1750) & & & $\begin{array}{l}-0.003 \\
(0.006)\end{array}$ & & & $\begin{array}{l}-0.007 \\
(0.007)\end{array}$ & & \\
\hline Centuries of Jesuit presence (bef. 1763) & & & & $\begin{array}{c}0.015 \\
(0.037)\end{array}$ & & $\begin{array}{c}0.017 \\
(0.041)\end{array}$ & $\begin{array}{c}0.060^{* * *} \\
(0.018)\end{array}$ & $\begin{array}{c}0.040 \\
(0.070)\end{array}$ \\
\hline Huguenots per 10,000 inhab. (1815) & & & & & $\begin{array}{c}0.000 \\
(0.000)\end{array}$ & $\begin{array}{c}0.000 \\
(0.000)\end{array}$ & & \\
\hline 1 (Abbeys $>0)$ & & & & & & & & $\begin{array}{l}0.062^{+} \\
(0.042)\end{array}$ \\
\hline 1 (Centuries of Jesuit presence $>0)$ & & & & & & & & $\begin{array}{c}0.038 \\
(0.112)\end{array}$ \\
\hline Observations & 82 & 83 & 82 & 83 & 81 & 79 & 31,326 & 31,326 \\
\hline Clusters (districts) & . & . & . & . & . & . & 502 & 502 \\
\hline$R^{2}$ & 0.02 & 0.01 & 0.02 & 0.01 & 0.01 & 0.05 & 0.03 & 0.04 \\
\hline
\end{tabular}


Figure A4.1.1: Persistence of religiosity in the 19th and 20th centuries

Note: This figure displays the spatial distribution of religiosity in the 19th and 20th centuries.

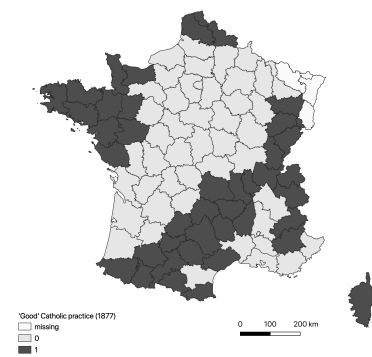

(Panel A) 'Good' Catholic practice (1877)

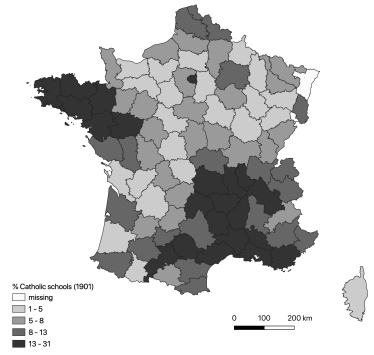

(Panel B) Share of Catholic schools (1901)

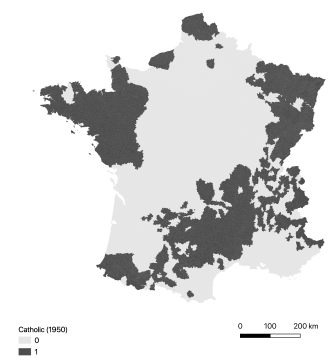

(Panel C) Catholic (1950)

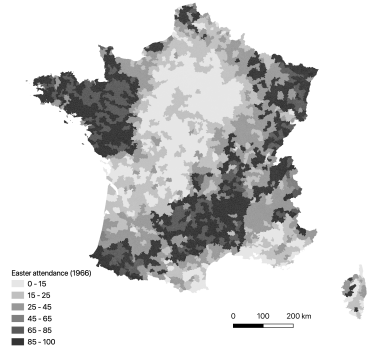

(Panel D) Easter attendance (1966)

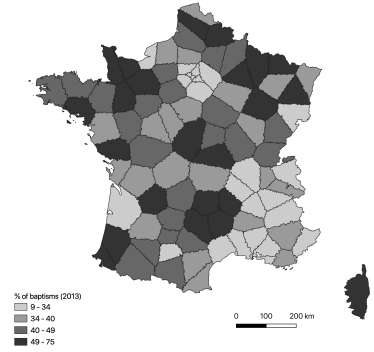

(Panel E) Baptisms/births (2013)

A4.2 Religiosity or secularization?

Table A4.2.1: Religiosity in 1791 and secularization in Provence

\begin{tabular}{|c|c|c|c|c|c|}
\hline & \multicolumn{5}{|c|}{ dep var: } \\
\hline & \multicolumn{4}{|c|}{ Ref. clergy: Religiosity (1791) } & \multirow{2}{*}{$\begin{array}{c}\text { (5) Secular } \\
\text { wills (1780-9) }\end{array}$} \\
\hline & (1) & (2) & (3) & (4) & \\
\hline Share of secular wills (1690-9) & $\begin{array}{l}1.922^{*} \\
(1.100)\end{array}$ & & $\begin{array}{c}3.114^{* * *} \\
(0.179)\end{array}$ & & \\
\hline Share of secular wills (1780-9) & & $\begin{array}{c}-0.560^{* * * *} \\
(0.189)\end{array}$ & $\begin{array}{c}-0.944^{* * *} \\
(0.076)\end{array}$ & & \\
\hline Change in $\%$ of secular wills & & & & $\begin{array}{c}-0.887^{* * *} \\
(0.203)\end{array}$ & $\begin{array}{c}1.026^{* * *} \\
(0.092)\end{array}$ \\
\hline Constant & $\begin{array}{c}0.007 \\
(0.197) \\
\end{array}$ & $\begin{array}{c}0.712^{* * *} \\
(0.099) \\
\end{array}$ & $\begin{array}{c}0.592^{* * *} \\
(0.038) \\
\end{array}$ & $\begin{array}{c}0.836^{* * *} \\
(0.171) \\
\end{array}$ & $\begin{array}{c}0.113 \\
(0.075)\end{array}$ \\
\hline Observations & 6 & 7 & 6 & 6 & 6 \\
\hline$R^{2}$ & 0.29 & 0.29 & 0.99 & 0.62 & 0.91 \\
\hline
\end{tabular}




\section{A4.3 Religiosity and development in France}

\section{Table A4.3.1: Religiosity in 1791 and development}

\begin{tabular}{|c|c|c|c|c|c|c|c|c|}
\hline & \multicolumn{2}{|c|}{ log population (1793) } & \multicolumn{2}{|c|}{ Dummy $=1$ if urban (1793) } & \multicolumn{2}{|c|}{$\log 1+$ Encycl. (1777-79) } & \multicolumn{2}{|c|}{ Soldier height $(<1760)$} \\
\hline & \multicolumn{2}{|c|}{ OLS } & \multicolumn{2}{|c|}{ Logit } & \multicolumn{2}{|c|}{ OLS } & \multicolumn{2}{|c|}{ OLS } \\
\hline & $(1)$ & $(2)$ & $(3)$ & $(4)$ & (5) & (6) & $(7)$ & $(8)$ \\
\hline \multicolumn{9}{|l|}{ Religiosity (1791) } \\
\hline Marginal effect & $\begin{array}{c}0.923^{* * *} \\
(0.168)\end{array}$ & $\begin{array}{c}0.594^{* * *} \\
(0.180)\end{array}$ & $\begin{array}{c}0.133^{* * *} \\
(0.030)\end{array}$ & $\begin{array}{c}0.083^{* *} \\
(0.042)\end{array}$ & $\begin{array}{c}0.414^{* *} \\
(0.181)\end{array}$ & $\begin{array}{c}0.099 \\
(0.155)\end{array}$ & $\begin{array}{l}0.196^{*} \\
(0.106)\end{array}$ & $\begin{array}{l}0.206^{*} \\
(0.110)\end{array}$ \\
\hline \multicolumn{9}{|l|}{ Controls } \\
\hline Religiosity (pre-secularization) & & Yes & & Yes & & Yes & & Yes \\
\hline Individual-level controls & & & & & & & Yes & Yes \\
\hline Observations & 32,116 & 32,116 & 32,116 & 32,116 & 32,116 & 32,116 & 12,943 & 12,943 \\
\hline Clusters (districts) & 510 & 510 & 510 & 510 & 510 & 510 & 407 & 407 \\
\hline$R^{2}$ & 0.02 & 0.18 & . & . & 0.01 & 0.29 & 0.10 & 0.10 \\
\hline
\end{tabular}


Appendix 5- Main empirical findings at the Département Level

\section{A5.1 Baseline results}

Table A5.1.1: Determinants of transition date: alternative definitions

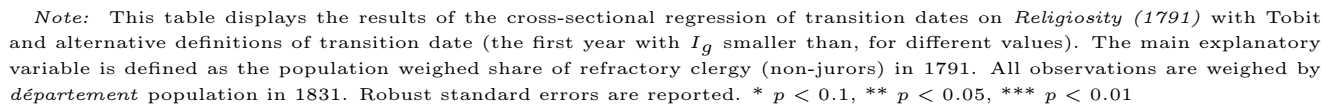

Note: This table displays the results of the cross-sectional regression of transition dates on Religiosity (1791) with Tobit and alternative definitions of transition date (the first year with $I_{g}$ smaller than, for different values). The main explanatory variable is defined as the population weighed share of refractory clergy (non-jurors) in 1791 . All observations are weighed by département population in 1831. Robust standard errors are reported. $* p<0.1, * * p<0.05, * * * p<0.01$

\begin{tabular}{lcccccc}
\hline \hline & \multicolumn{5}{c}{ dep var: Transition date } \\
\cline { 2 - 6 } & $(1) I_{g} \leq .3$ & $(2) I_{g} \leq .4$ & $(3) I_{g} \leq .5$ & $(4) I_{g} \leq .6$ & $(5) I_{g} \leq .7$ \\
\hline \multirow{2}{*}{ Religiosity (1791) } & $66.802^{* * *}$ & $86.222^{* * *}$ & $118.603^{* * *}$ & $136.693^{* * *}$ & $83.143^{* *}$ \\
& $(20.607)$ & $(15.333)$ & $(16.896)$ & $(29.382)$ & $(35.045)$ \\
& & & & & 51 & 70 \\
\hline Left censored observations (<1831) & 0 & 6 & 24 & 0 & 0 \\
Right censored observations (>1961) & 35 & 3 & 0 & 85 & 85 \\
Observations & 85 & 85 & 85 & 85 \\
\hline \hline
\end{tabular}

Figure A5.1.1: Determinants of transition date

Note: This figure displays the results of the same regression as in specifications (1) and (7) (estimated with OLS) in Table 2 .

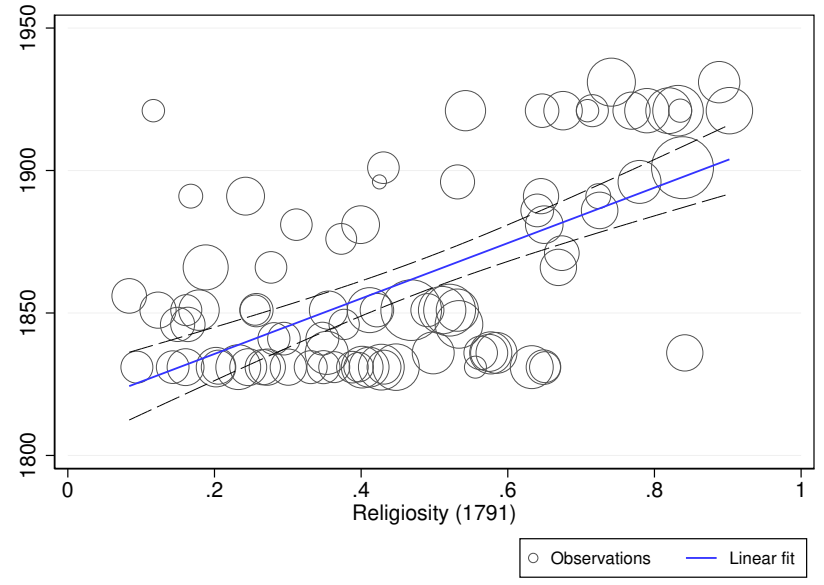

(Panel A) Scatterplot

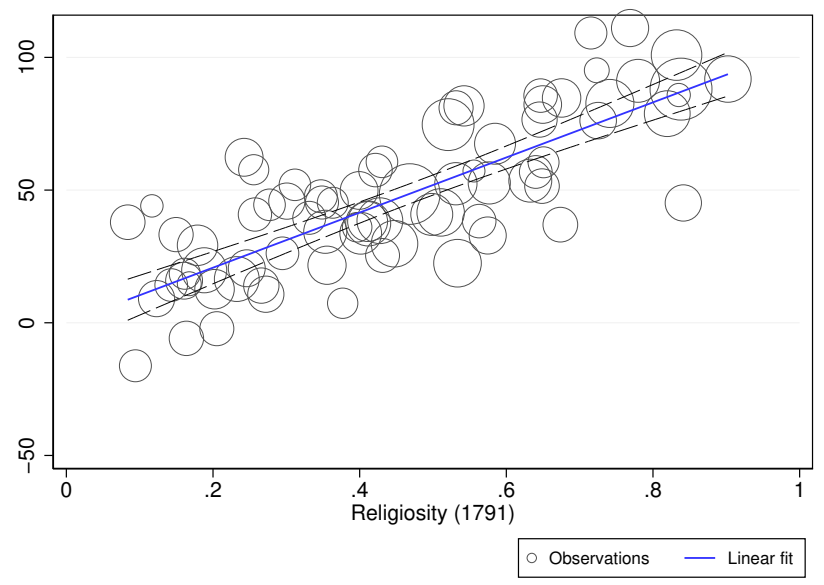

(Panel B) Partial residual plot (full set of controls) 
Table A5.1.2: Determinants of $I_{g}$

\begin{tabular}{|c|c|c|c|c|c|c|c|}
\hline & & & dep var: $\mathrm{I}$ & ertility ind & x $I_{g} 1851$ & & \\
\hline & (1) & $(2)$ & (3) & (4) & $(5)$ & (6) & (7) \\
\hline Religiosity (1791) & $\begin{array}{c}0.277^{* * * *} \\
(0.049)\end{array}$ & $\begin{array}{c}0.281^{* * *} \\
(0.048)\end{array}$ & $\begin{array}{c}0.207^{* * * *} \\
(0.044)\end{array}$ & $\begin{array}{c}0.269^{* * *} \\
(0.061)\end{array}$ & $\begin{array}{c}0.268^{* * * *} \\
(0.062)\end{array}$ & $\begin{array}{c}0.269^{* * *} \\
(0.071)\end{array}$ & $\begin{array}{c}0.260^{* * *} \\
(0.076)\end{array}$ \\
\hline Controls & & & & & & & \\
\hline Religiosity (pre-secularization) & & Yes & Yes & Yes & Yes & Yes & Yes \\
\hline Cultural and institutional factors & & & Yes & Yes & Yes & Yes & Yes \\
\hline Region fixed effects & & & & Yes & Yes & Yes & Yes \\
\hline Education and schooling & & & & & Yes & Yes & Yes \\
\hline Pre-industrial development & & & & & & Yes & Yes \\
\hline Contemporary development & & & & & & & Yes \\
\hline Mean of $I_{g}(1851)$ & .49 & .49 & .49 & .49 & .49 & .49 & .49 \\
\hline Standard deviation of $I_{g}(1851)$ & .11 & .11 & .11 & .11 & .11 & .11 & .11 \\
\hline Perc. 25-75 Religiosity (1791) & .10 & .10 & .07 & .09 & .09 & .09 & .09 \\
\hline Observations & 83 & 79 & 76 & 76 & 76 & 76 & 76 \\
\hline Adjusted $R^{2}$ & 0.29 & 0.31 & 0.53 & 0.62 & 0.62 & 0.60 & 0.60 \\
\hline
\end{tabular}

(Panel A) 1851

\begin{tabular}{|c|c|c|c|c|c|c|c|}
\hline & \multicolumn{7}{|c|}{ dep var: Fertility index $I_{g} 1901$} \\
\hline & (1) & $(2)$ & $(3)$ & $(4)$ & $(5)$ & $(6)$ & $(7)$ \\
\hline Religiosity (1791) & $\begin{array}{c}0.304^{* * *} \\
(0.054)\end{array}$ & $\begin{array}{c}0.309 * * * \\
(0.049)\end{array}$ & $\begin{array}{c}0.245^{* * *} \\
(0.042)\end{array}$ & $\begin{array}{c}0.237 * * * \\
(0.059)\end{array}$ & $\begin{array}{c}0.241 * * * \\
(0.057)\end{array}$ & $\begin{array}{c}0.237^{* * *} \\
(0.059)\end{array}$ & $\begin{array}{c}0.237^{* * *} \\
(0.060)\end{array}$ \\
\hline \multicolumn{8}{|l|}{ Controls } \\
\hline Religiosity (pre-secularization) & & Yes & Yes & Yes & Yes & Yes & Yes \\
\hline Cultural and institutional factors & & & Yes & Yes & Yes & Yes & Yes \\
\hline Region fixed effects & & & & Yes & Yes & Yes & Yes \\
\hline Education and schooling & & & & & Yes & Yes & Yes \\
\hline Pre-industrial development & & & & & & Yes & Yes \\
\hline Contemporary development & & & & & & & Yes \\
\hline Mean of $I_{g}(1901)$ & .39 & .38 & .38 & .38 & .38 & .38 & .38 \\
\hline Standard deviation of $I_{g}(1901)$ & .11 & .11 & .10 & .10 & .10 & .10 & .10 \\
\hline Perc. 25-75 Religiosity (1791) & .10 & .10 & .08 & .08 & .08 & .08 & .08 \\
\hline Observations & 82 & 77 & 75 & 75 & 75 & 75 & 75 \\
\hline Adjusted $R^{2}$ & 0.32 & 0.48 & 0.59 & 0.68 & 0.69 & 0.68 & 0.67 \\
\hline
\end{tabular}

(Panel B) 1901

Figure A5.1.2: Magnitude and importance of the determinants of marital fertility (1831-1901) 
Note: This figure displays standardized beta coefficients of the cross-sectional regression of the marital fertility index $I_{g}$ on variables of interest over time. Panel A reports the results of univariate regressions with the listed variable as the only explanatory variable. Panel B plots the coefficient on each of these variable, controlling for the full set of controls. Hence, in Panel B, all standardized coefficients correspond to the same regression (specification 7).

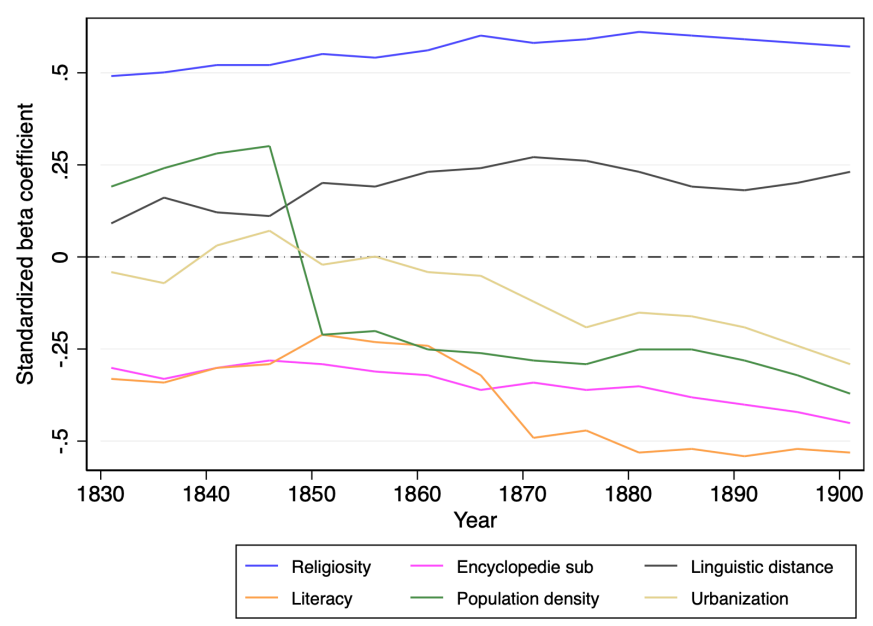

(Panel A) Univariate regressions (no controls)

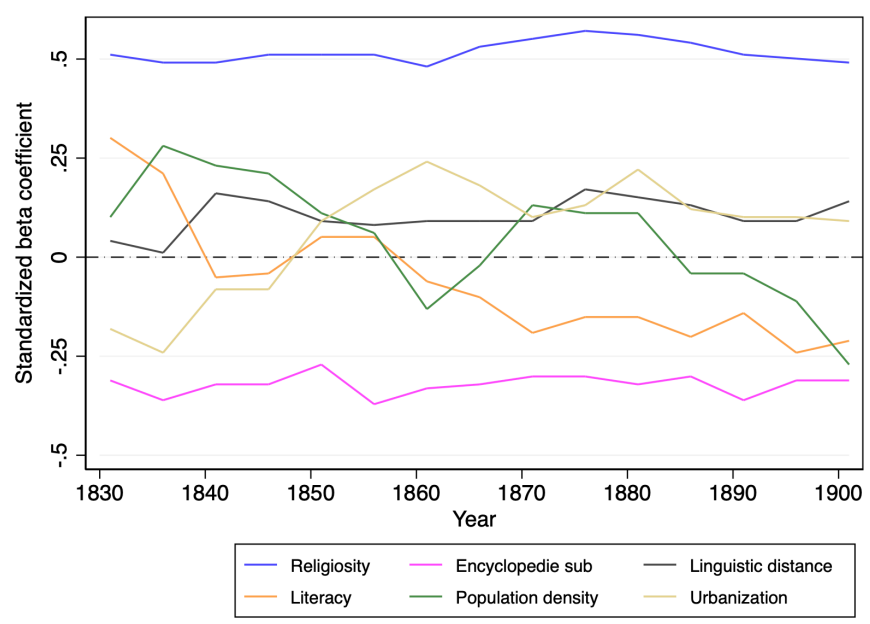

(Panel B) Full set of controls 
A5.2 Alternative explanations and robustness: lasso estimation and sensitivity analysis

Figure A5.2.1: Determinants of transition date: distribution of estimates and t-statistics across all combinations of controls (with fixed effects)

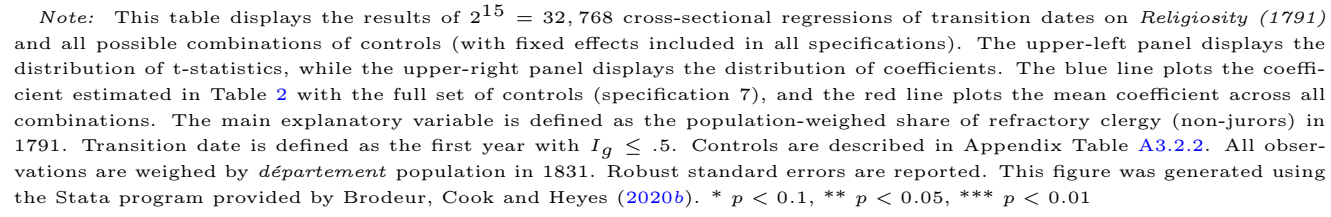

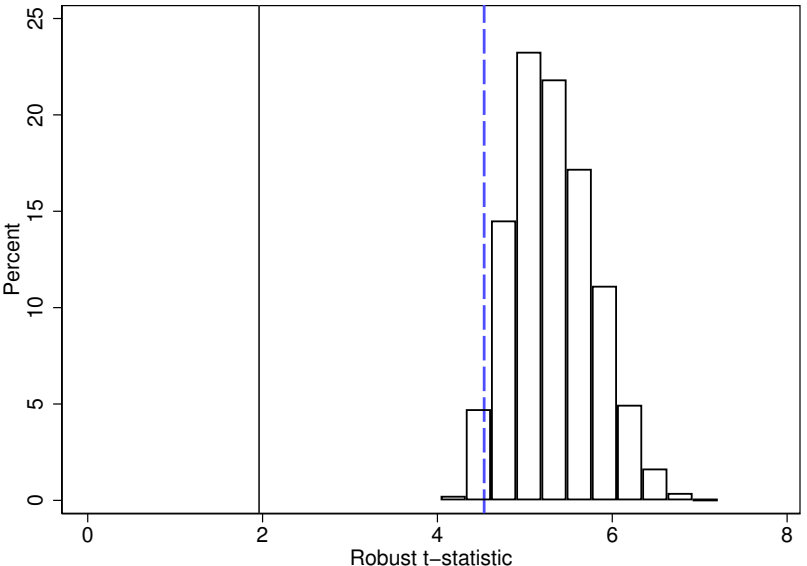

(Panel A) t-statistic curve

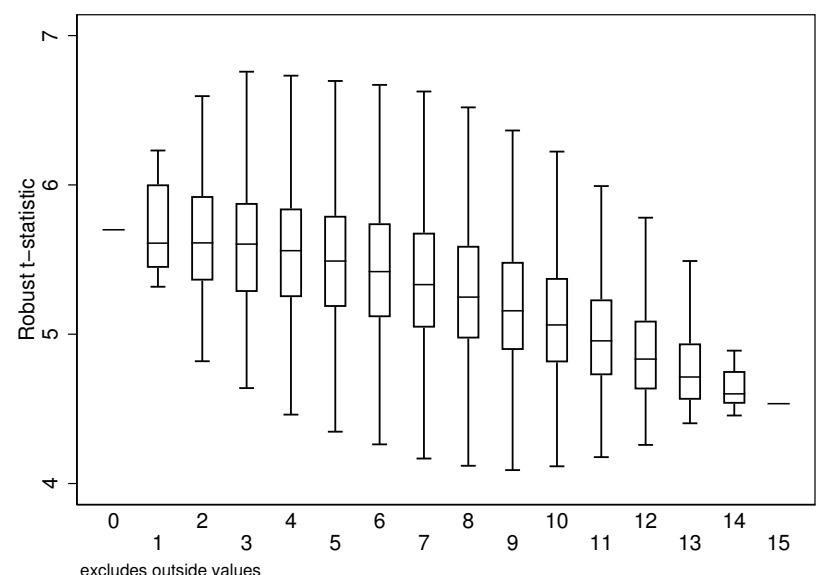

(Panel C) t-statistic by \# of controls

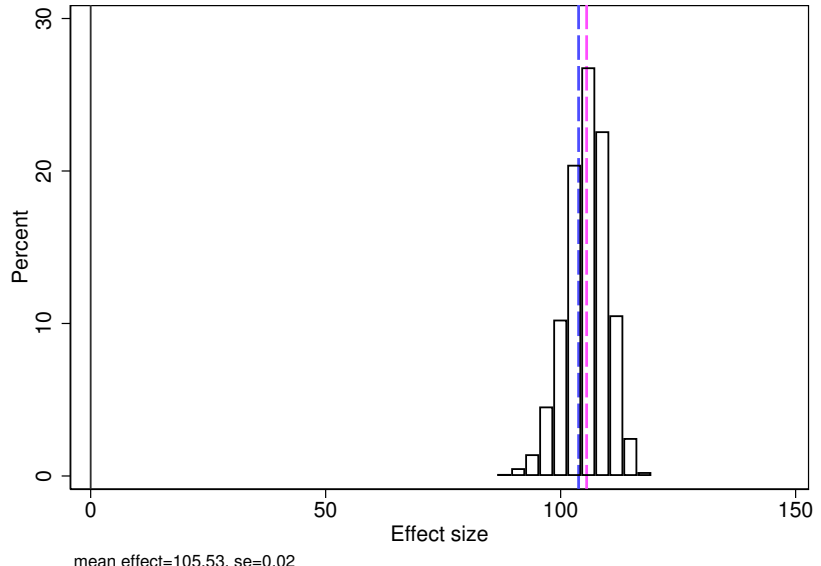

(Panel B) Effect curve

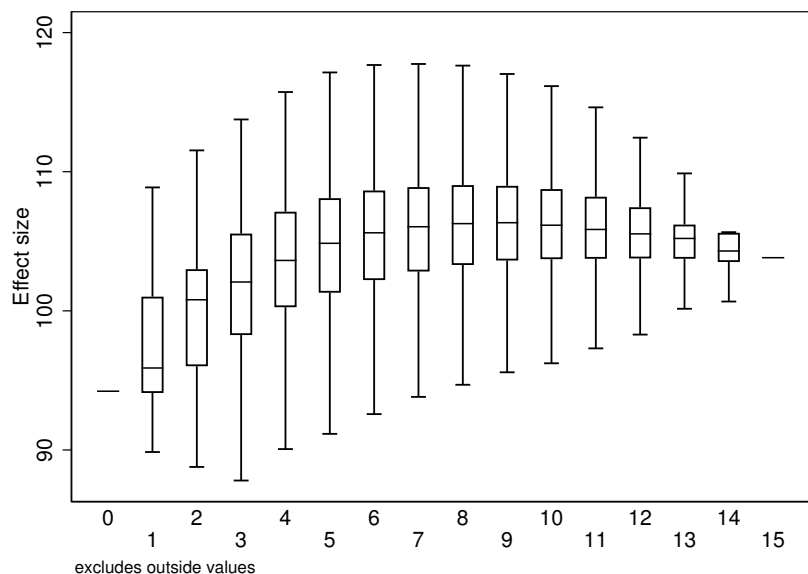

(Panel D) Effect size by \# of controls 
Figure A5.2.2: Determinants of transition date: distribution of estimates and t-statistics across all combinations of controls (without fixed effects)

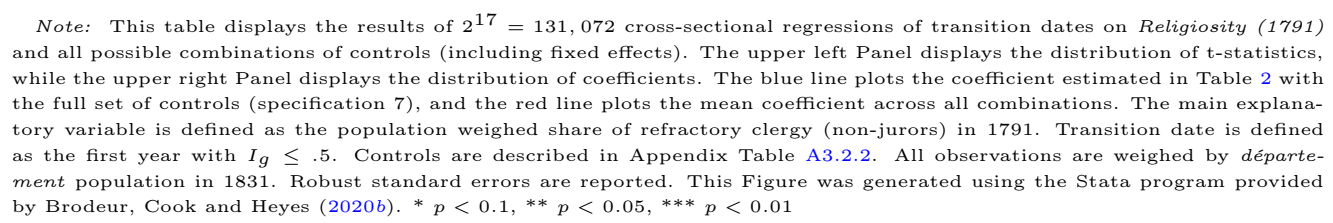

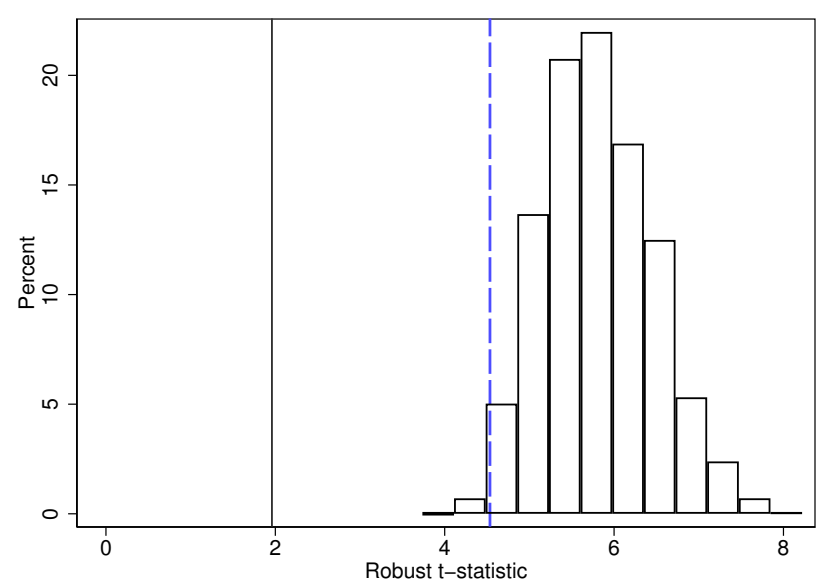

(Panel A) t-statistic curve

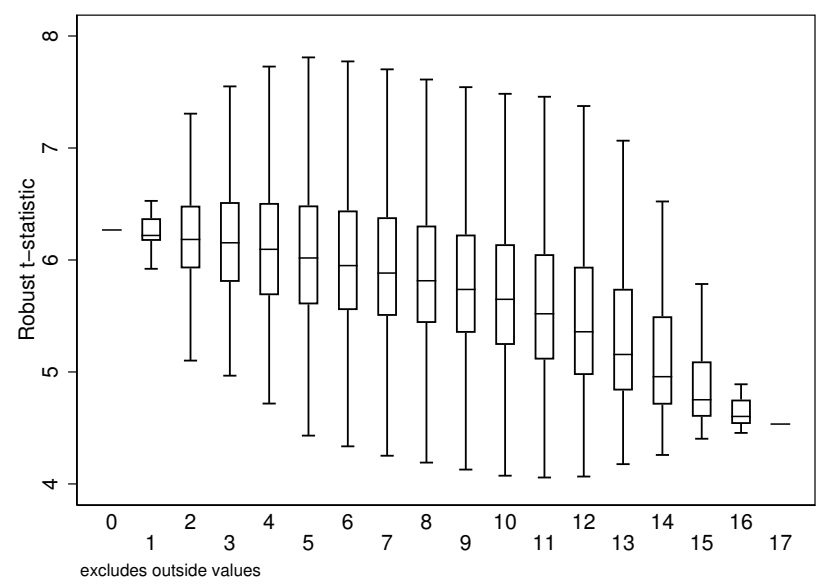

(Panel C) t-statistic by \# of controls

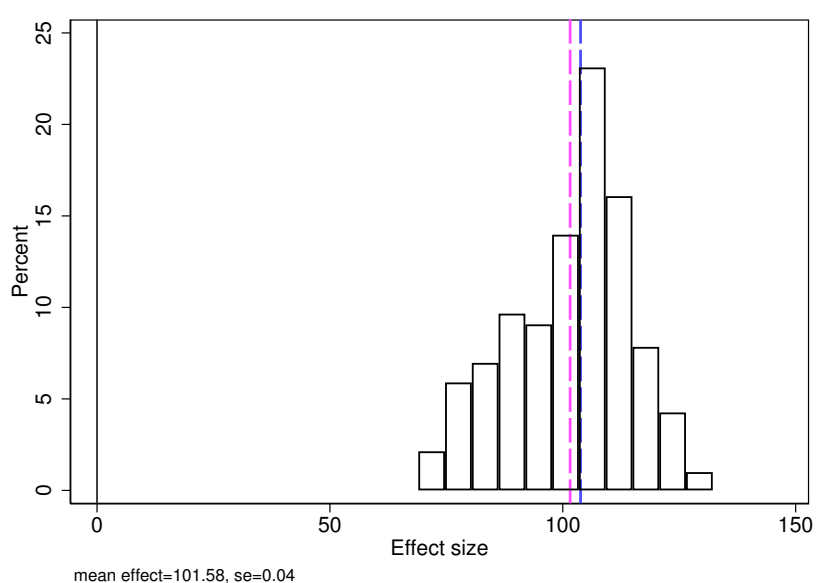

(Panel B) Effect curve

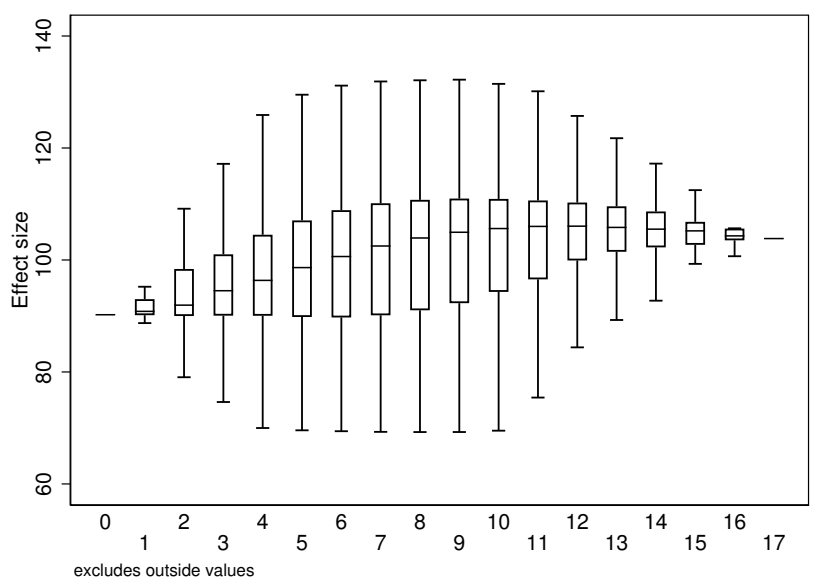

(Panel D) Effect size by \# of controls 
Table A5.2.1: Double lasso estimation of the determinants of transition date

\begin{tabular}{|c|c|c|c|c|c|}
\hline \multicolumn{6}{|c|}{$\begin{array}{l}\text { The main explanatory variable is defined as the population-weighed share of refractory clergy (non-jurors) } \\
\text { date is defined as the first year with } I_{g} \leq .5 \text {. The tuning parameter } \lambda \text { is chosen by cross-validation. The } \mathrm{s} \text {, } \\
\text { trols to be chosen by the double lasso procedure is described in Appendix Table A3.2.2. In specifications } 3 \text {, } \\
\text { selection of Encyclopédie subscriptions (3), region and pays-status fixed effects (4), or both (5) as controls } \\
\text { not weighed by département population; therefore specification } 1 \text { corresponds to the same specification as } \\
\text { Table 2, estimated without weighing by population. Robust standard errors are reported. } p<0.1, * * p< \\
\text { dep var: transition date }\end{array}$} \\
\hline & \multirow[b]{2}{*}{ (1) OLS } & \multicolumn{4}{|c|}{ LASSO } \\
\hline & & $(2)$ & $(3)$ & $(4)$ & $(5)$ \\
\hline Religiosity (1791) & $\begin{array}{c}102.600^{* * *} \\
(21.944)\end{array}$ & $\begin{array}{c}83.792^{* * * *} \\
(15.059)\end{array}$ & $\begin{array}{c}84.847^{* * *} \\
(14.417)\end{array}$ & $\begin{array}{c}102.403^{* * *} \\
(18.916)\end{array}$ & $\begin{array}{c}106.515^{* * *} \\
(17.957)\end{array}$ \\
\hline Controls always included & All & & & & \\
\hline Region \& pays status FE & & & & Yes & Yes \\
\hline $\log 1+$ Encyclopedie (1777-79) & & & Yes & & Yes \\
\hline \multicolumn{6}{|l|}{ Controls selected by LASSO } \\
\hline $\log 1+$ Encyclopedie (1777-79) & & & Yes & & Yes \\
\hline Share of deserters among conscripts (1798-1805) & & & & Yes & Yes \\
\hline Clergymen per 10,000 inhabitants (1791) & & & & Yes & \\
\hline Linguistic distance from French (1900) & & & & Yes & \\
\hline Books printed (1500) & & & & Yes & Yes \\
\hline $\log 1+$ Urbanization (1831) & & & & Yes & \\
\hline Soldier height (bef. 1760) & & & & Yes & \\
\hline Number of controls selected & & $0 / 15$ & $1 / 15$ & $8 / 17$ & $5 / 17$ \\
\hline Observations & 76 & 85 & 85 & 76 & 76 \\
\hline Adjusted $R^{2}$ & 0.56 & . & . & . & . \\
\hline
\end{tabular}

Figure A5.2.3: Coefficient path (with FE) 
Note: This figure displays the coefficient path of the determinants of transition date (Panel A) and the determinants of religiosity in 1791 (Panel B), with fixed effects.

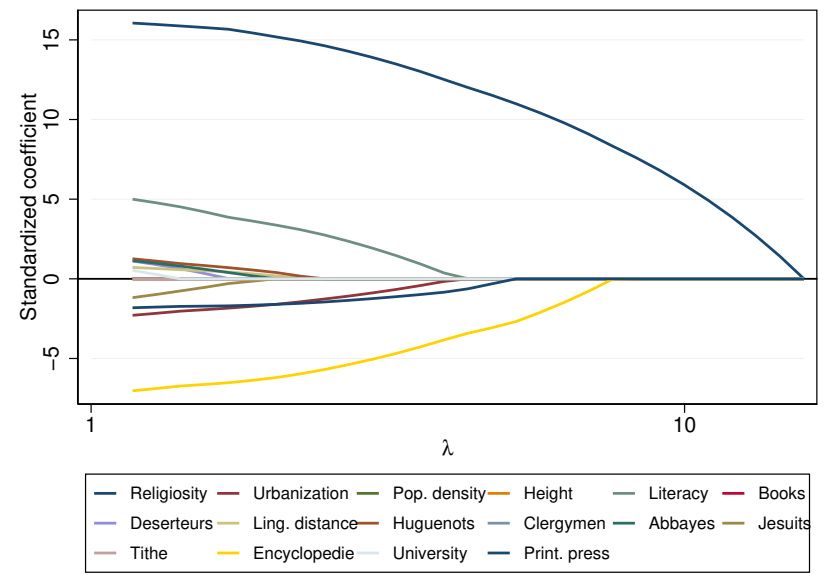

(Panel A) Transition date

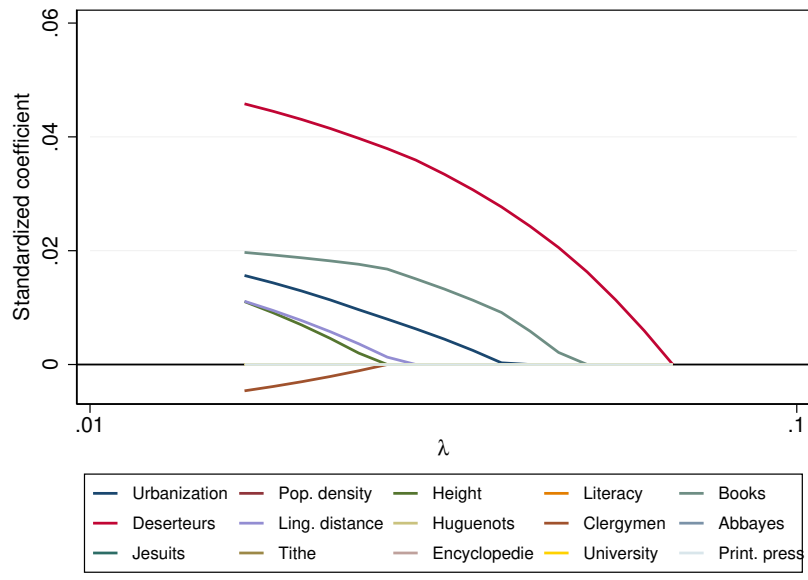

(Panel B) Religiosity (1791) 
A5.3 Accounting for omitted variables and spatial dependance

Table A5.3.1: Determinants of transition date: selection on unobservables

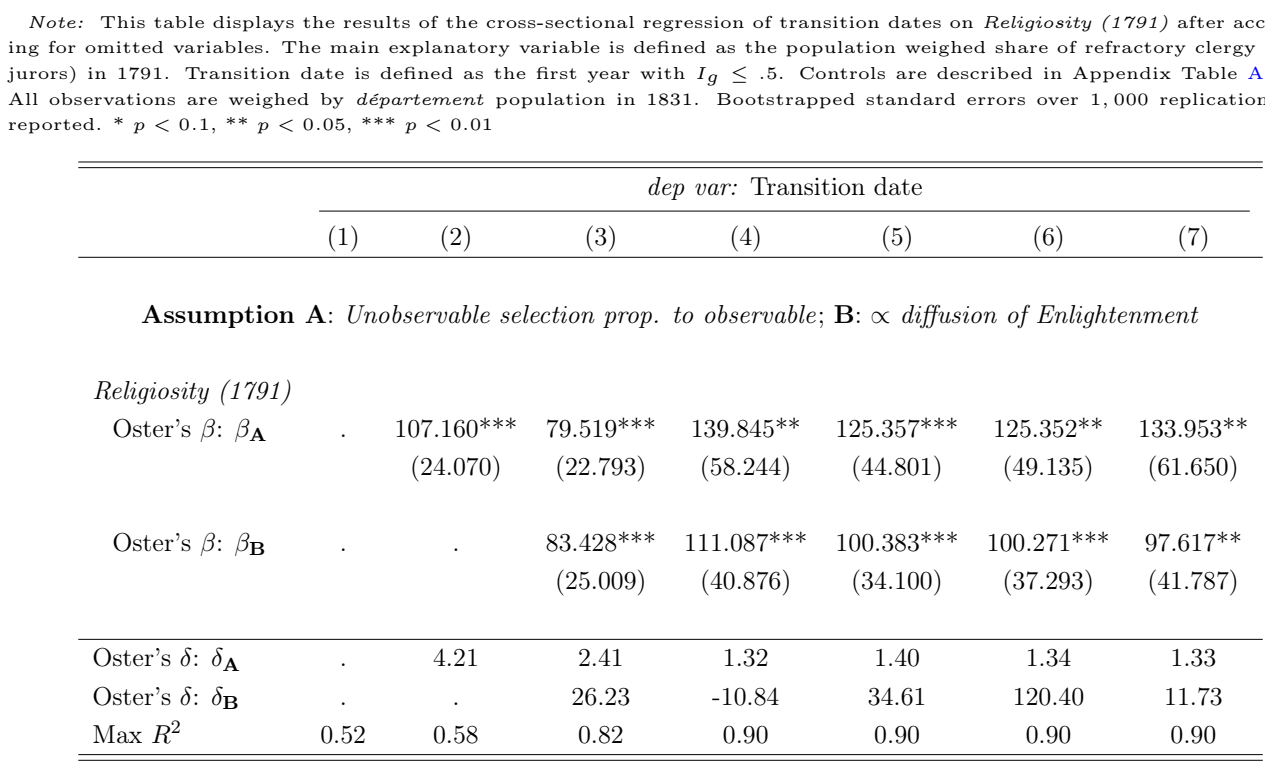

Figure A5.3.1: Accounting for unobservables (1831-1901)

\begin{abstract}
Note: This figure displays the estimated impact of Religiosity (1791) on marital fertility over time. Religiosity (1791) is defined as the population-weighed share of refractory clergy (non-jurors) in 1791. Panel A displays the estimated coefficients accounting for the full set of controls under no selection (OLS) and equal selection $\left(\beta_{B}\right)$, where Oster's beta is computed under Assumption ??. Panel B displays the marital-fertility index for France and for England and Wales over time, along with a counterfactual index for France.
\end{abstract}

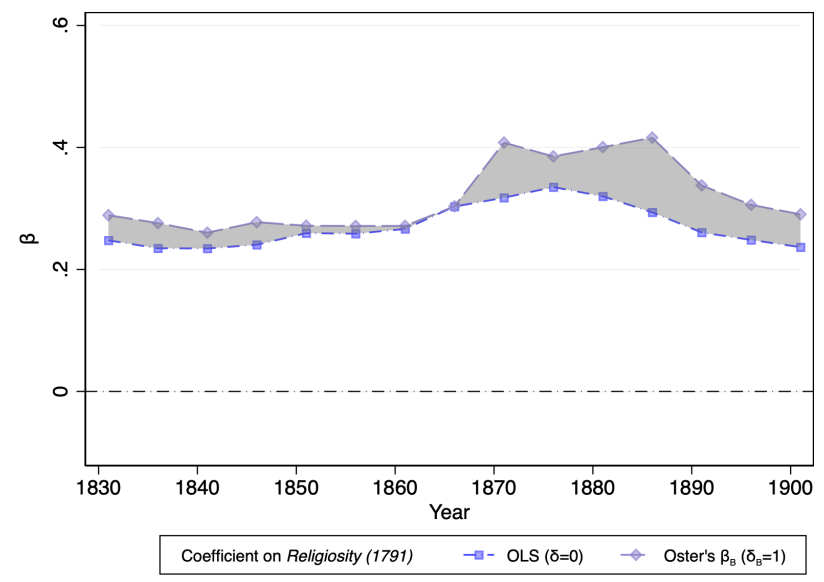

(Panel A) Omitted variables-adjusted coefficient

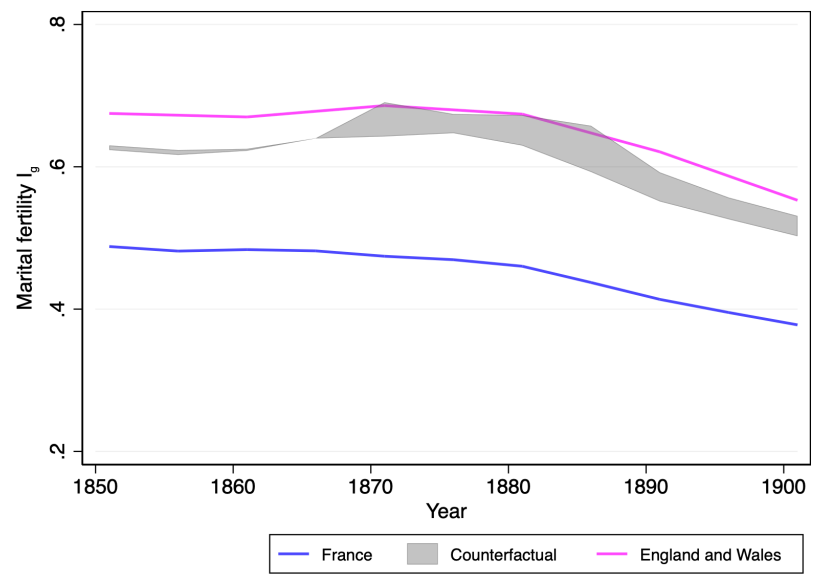

(Panel B) Counterfactual fertility 
Table A5.3.2: Accounting for spatial dependence in the determinants of transition date

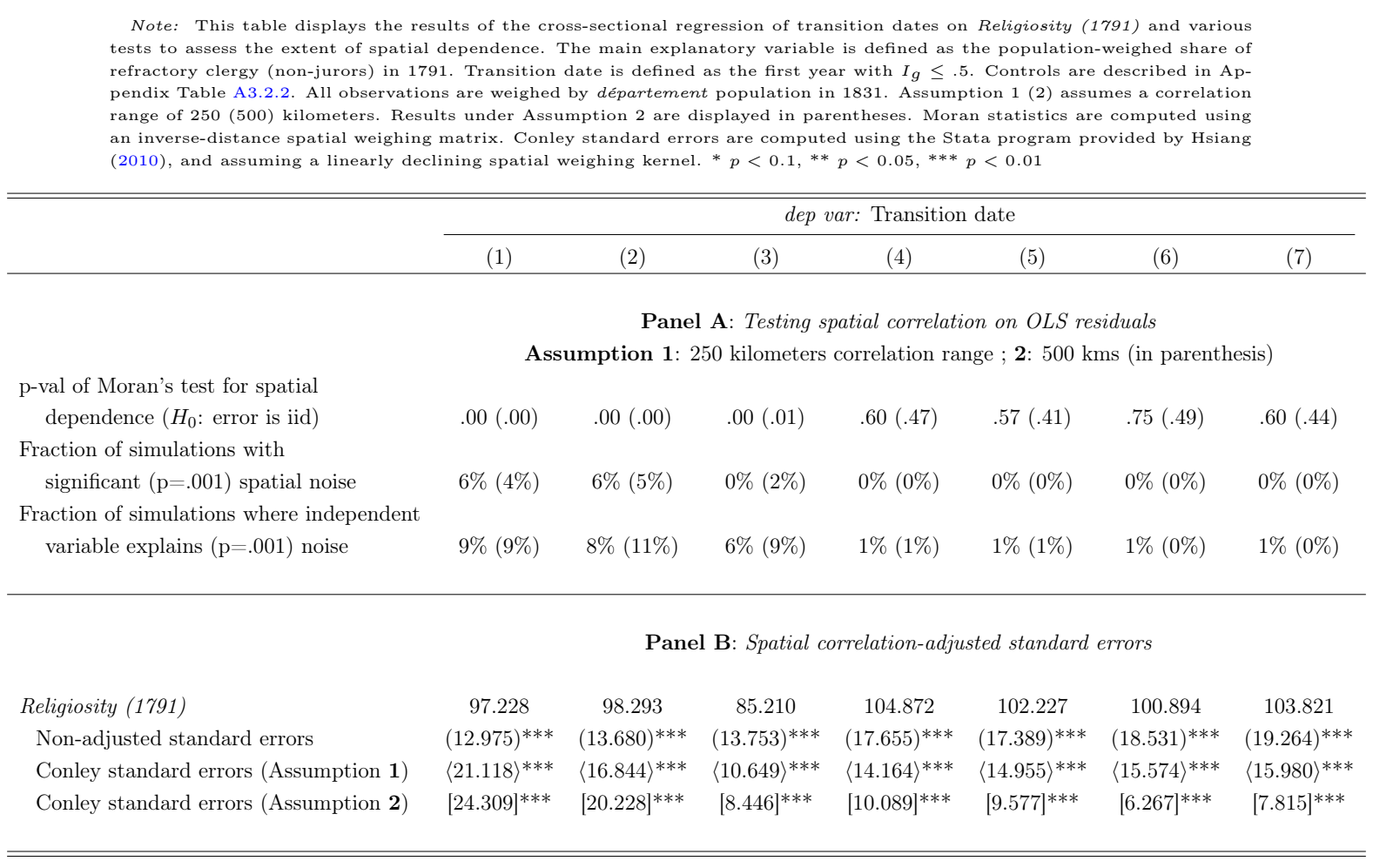




\section{ApPendix 6- Individual-Level Results}

A6.1 Baseline results

Figure A6.1.1: Age at birth of first and last child

Note: This figure displays age at birth of the first child (Panel A) and the average duration between births of children (Panel B) for women in the fertility sample.

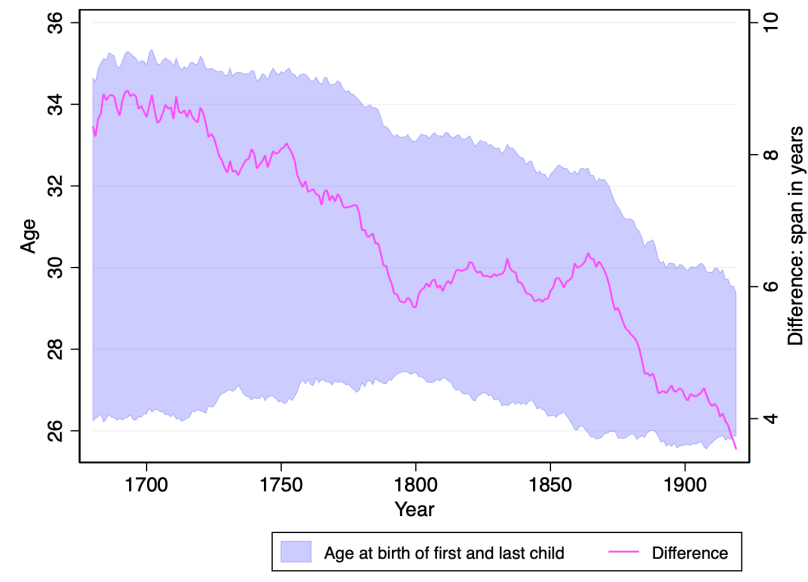

(Panel A) Age at birth of first and last child

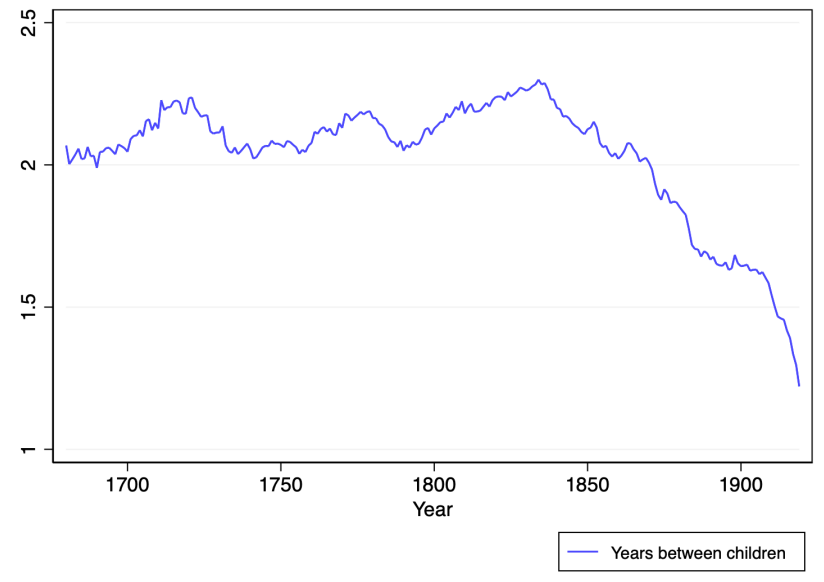

(Panel B) Average duration between birth of children

Figure A6.1.2: Counterfactual cumulative distribution of fertility

Note: This figure displays the observed and counterfactual CDF of fertility. The counterfactual is generated from the distribution regression in Figure 5, by setting religiosity in 1791 to maximum level. Religiosity (1791) is defined as the population weighed share of refractory clergy (non-jurors) in 1791. The distribution is plotted for up to 20 children (the maximum observed is 36 ).

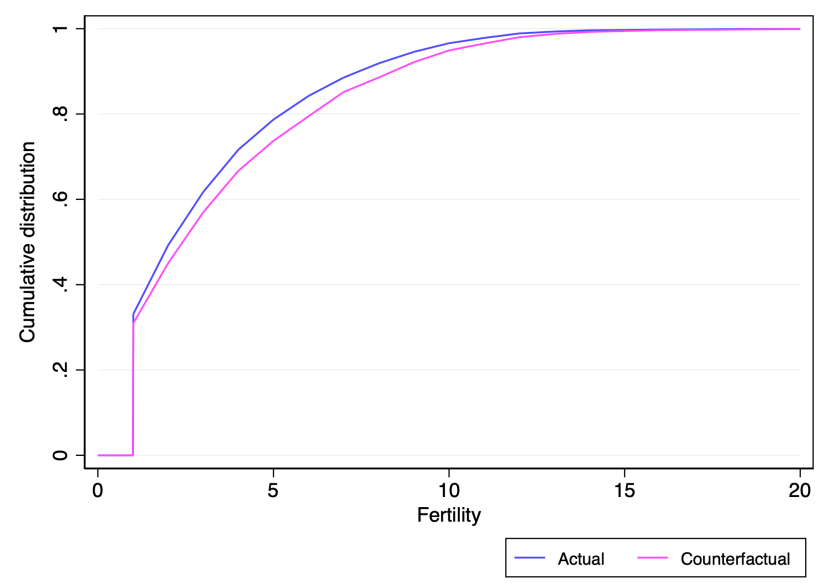


Table A6.1.1: Determinants of fertility at the individual level: robustness to estimation method

\begin{tabular}{|c|c|c|c|c|}
\hline & \multicolumn{4}{|c|}{ dep var: $\log$ fertility } \\
\hline & (1) OLS & (2) Poisson & $\begin{array}{l}\text { (3) Overdis. } \\
\text { Poisson }\end{array}$ & $\begin{array}{c}\text { (4) Negative } \\
\text { Binomial }\end{array}$ \\
\hline Religiosity (1791) & $\begin{array}{c}0.210^{* * *} \\
(0.073)\end{array}$ & $\begin{array}{c}0.274^{* * *} \\
(0.088)\end{array}$ & $\begin{array}{c}0.274^{* *} \\
(0.126)\end{array}$ & $\begin{array}{c}0.259 * * * \\
(0.082)\end{array}$ \\
\hline Marginal effect of religiosity on fertility & $0.973^{* * *}$ & $0.971^{* * *}$ & $0.971^{* *}$ & $0.919 * * *$ \\
\hline \multicolumn{5}{|l|}{ Controls } \\
\hline Individual-level & Yes & Yes & Yes & Yes \\
\hline Religiosity (pre-secularization) & Yes & Yes & Yes & Yes \\
\hline Cultural factors and development & Yes & Yes & Yes & Yes \\
\hline Shape parameter $=\alpha$ & & 0 & 0 & 0.26 \\
\hline Scale parameter $=\sqrt{\phi}$ & & 1 & 1.44 & 1 \\
\hline Observations & 11,649 & 11,649 & 11,649 & 11,649 \\
\hline Clusters (couples) & 10,155 & 10,155 & 10,155 & 10,155 \\
\hline Clusters (districts) & 438 & 438 & 438 & 438 \\
\hline (Pseudo) $R^{2}$ & 0.12 & 0.06 & & 0.03 \\
\hline
\end{tabular}


A6.2 Identification of a causal effect: fixed effects, differences-in-differences and second generation migrants analysis

Figure A6.2.1: Treatment distribution with and without fixed effects

Note: This figure displays the distribution of Religiosity (1791) (of district of birth, and of the district of birth of parents for second generation migrants) with and without fixed effects (département of birth by decade, and district of birth and decade FE for second generation migrants).

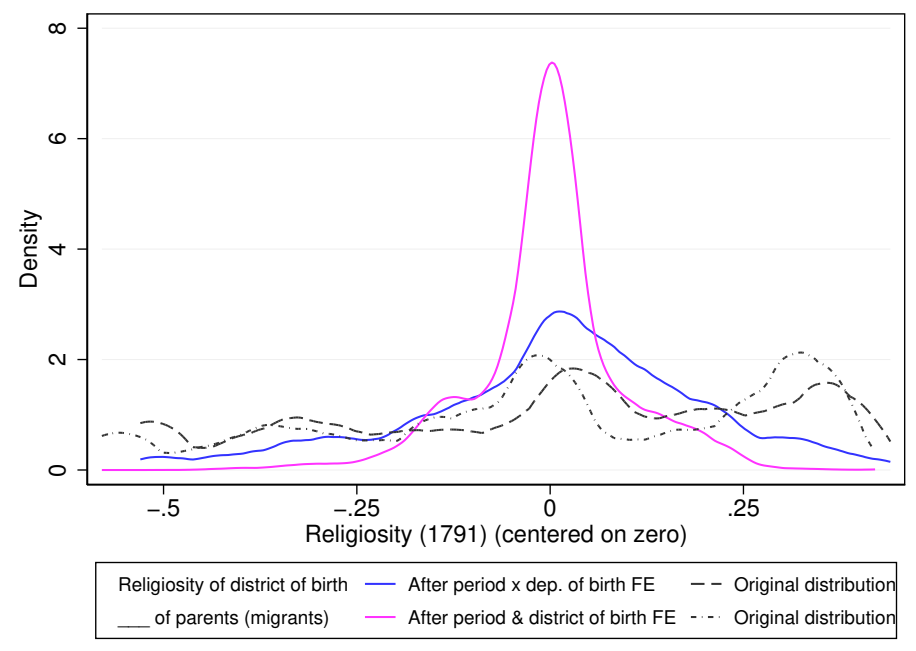

Figure A6.2.2: Effect of religiosity in 1791 over time

Note: This figure plots the effect of religiosity in 1791 on $\log$ fertility before and after secularization (Panel A) and over time, with 40 years periods (Panel B), along with 90\% (robust) CI. Religiosity (1791) is defined as the population weighed share of refractory clergy (non-jurors) in 1791. Panel A corresponds to specification (4) in Table 5. Panel B is estimated from the same specification but instead by interacting religiosity in 1791 with 40 years period dummies.

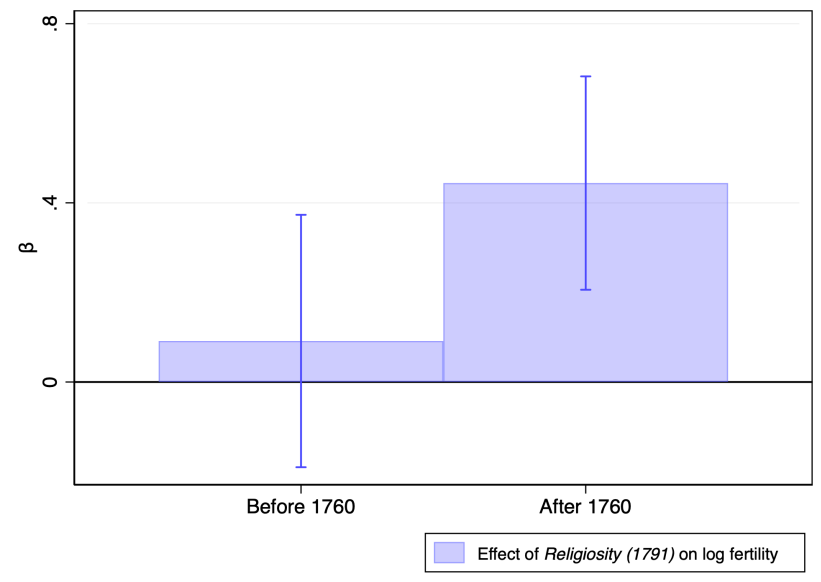

(Panel A) Before and after secularization

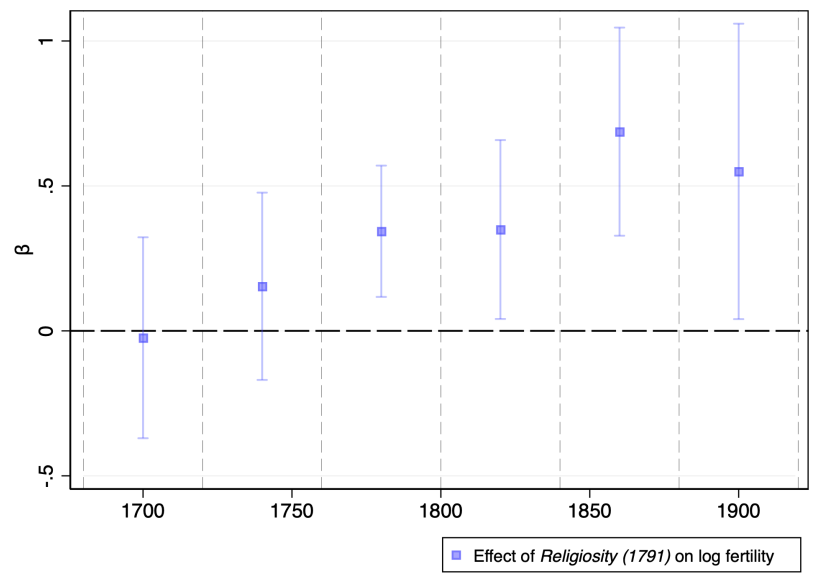

(Panel B) Over time 